\title{
Synthesis of 12-Membered Tetra-aza Macrocyclic Pyridinophanes Bearing Electron Withdrawing Groups
}

\author{
Akop Yepremyan, ${ }^{\dagger}$ Magy A. Mekhail,${ }^{\dagger}$ Brian P. Niebuhr, Kristof Pota, Nishanth Sadagopan, \\ Timothy M. Schwartz, Kayla N. Green*
}

Department of Chemistry and Biochemistry, Texas Christian University, 2950 W. Bowie, Fort Worth, TX 76129, United States, 'ंEqual contributions 


\section{Table of Contents}

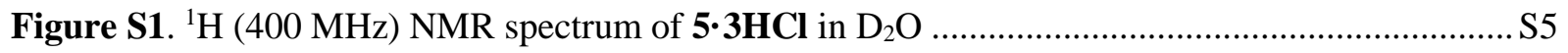

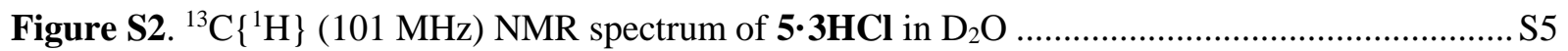

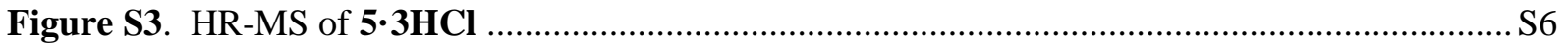

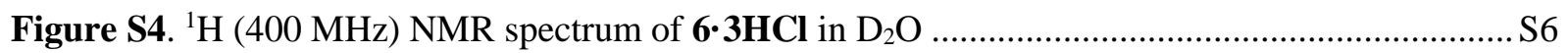

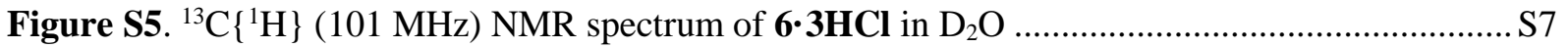

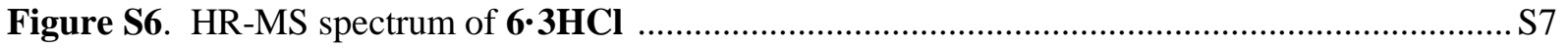

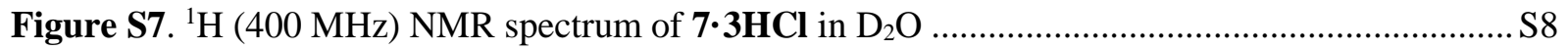

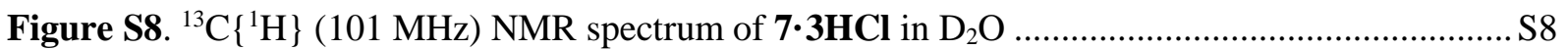

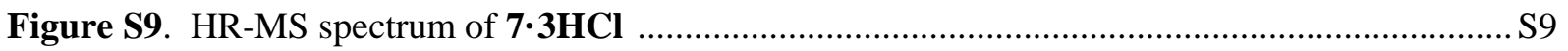

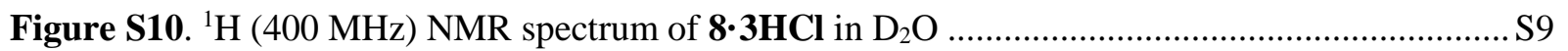

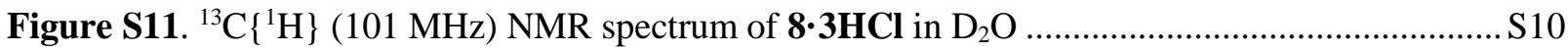

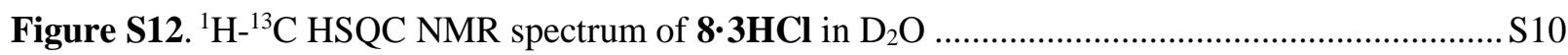

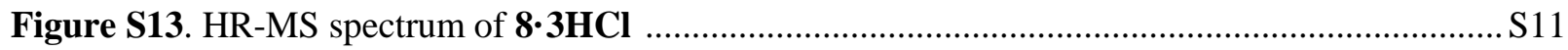

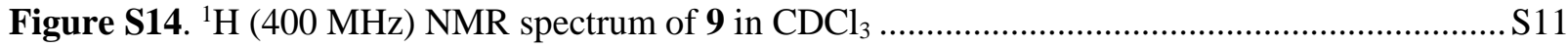

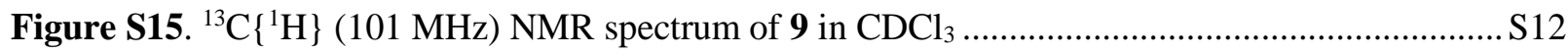

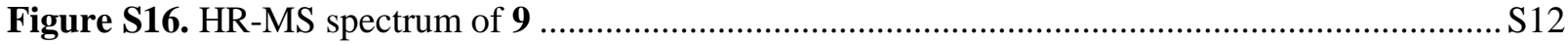

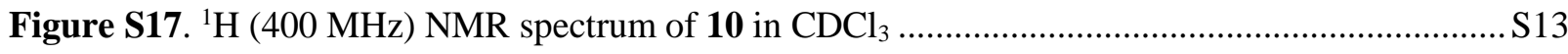

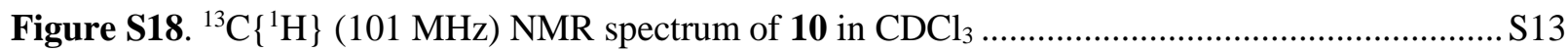

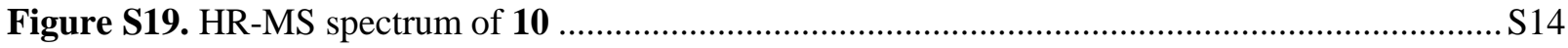

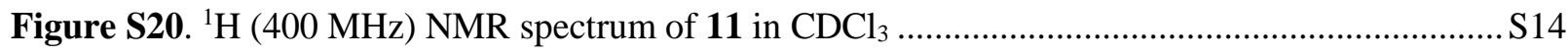

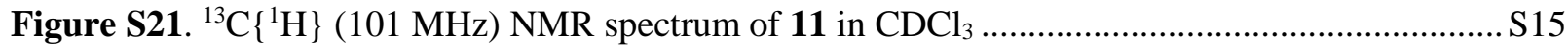

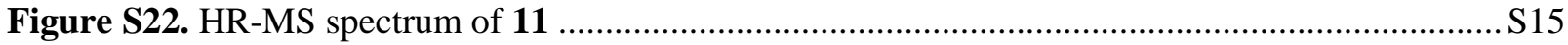

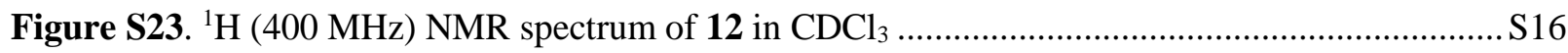

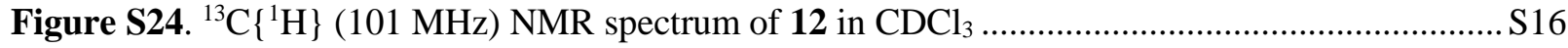

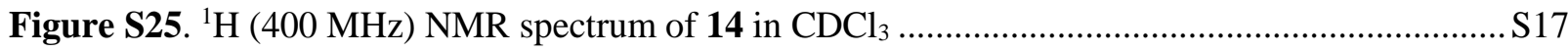

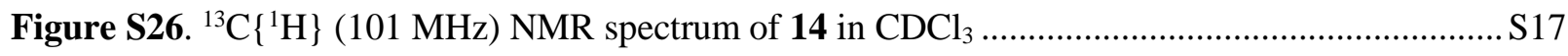

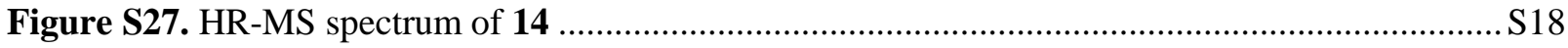

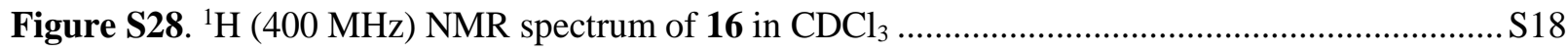

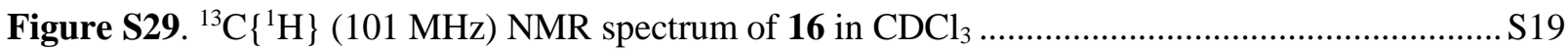




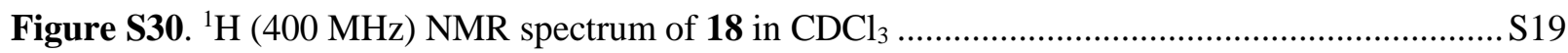

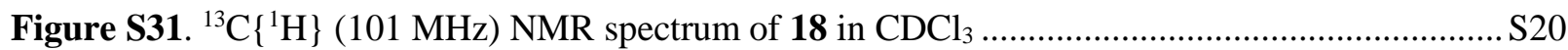

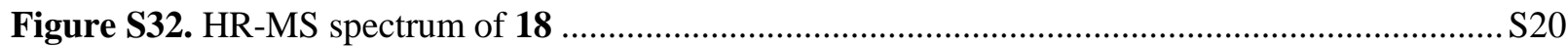

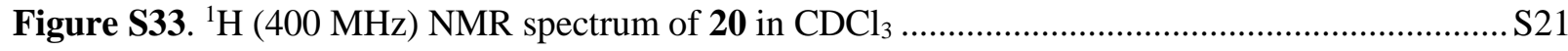

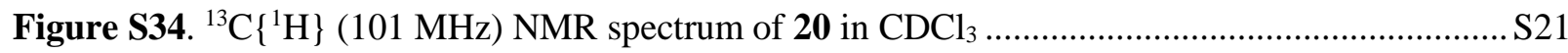

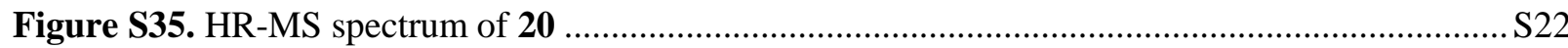

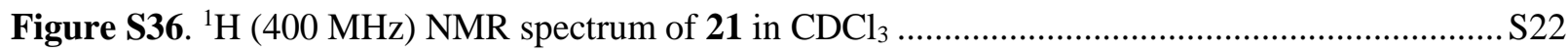

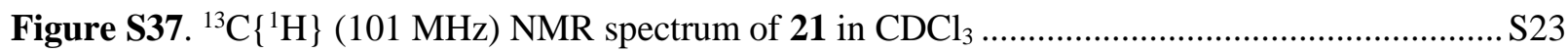

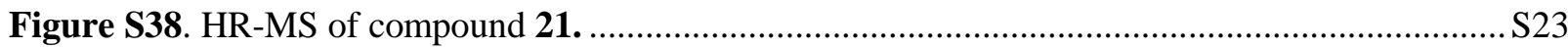

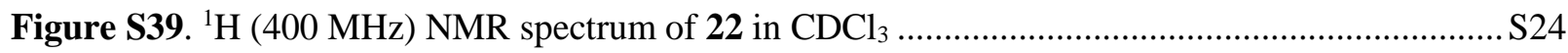

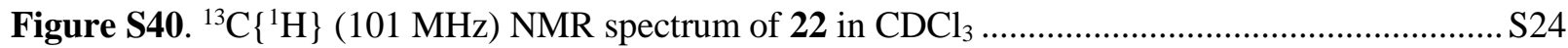

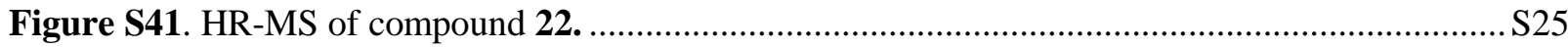

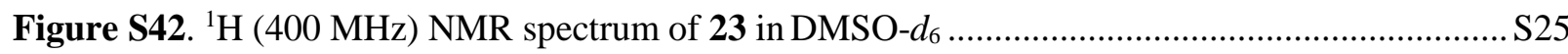

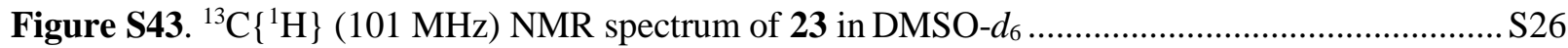

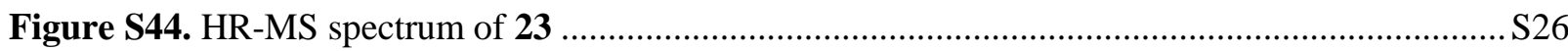

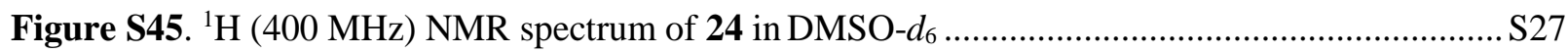

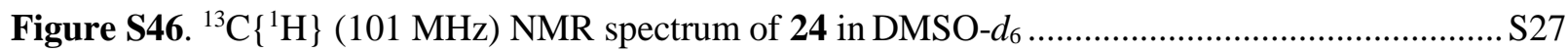

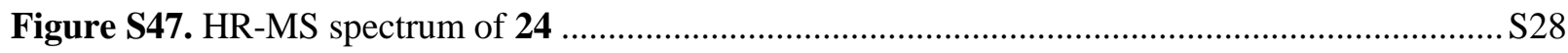

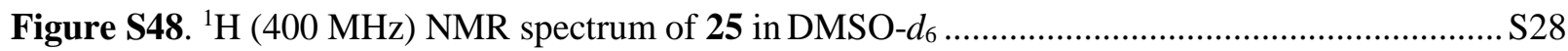

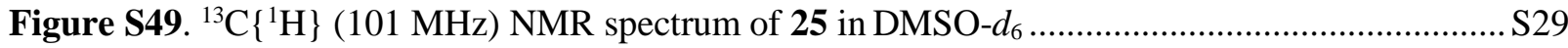

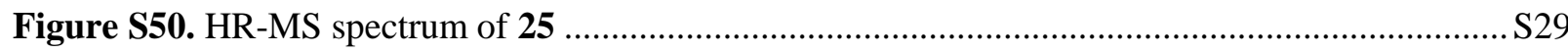

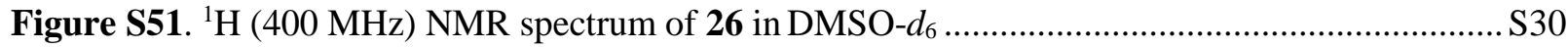

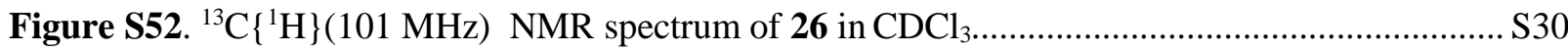

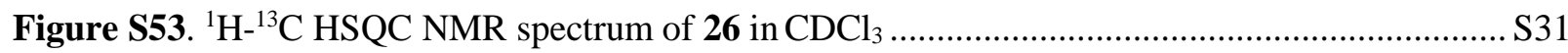

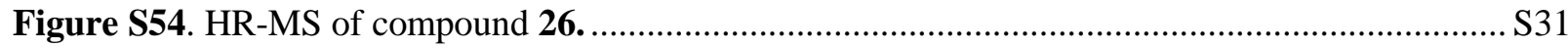

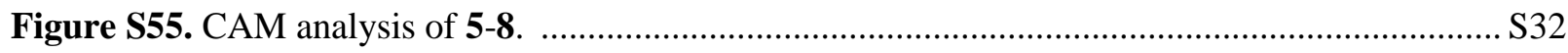

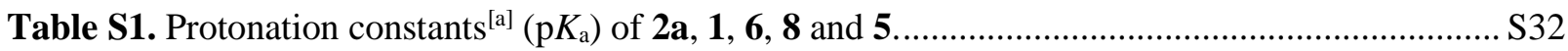

Figure S56. Solid state structure of $\mathbf{6} \cdot \mathbf{H C l} \cdot 2 \mathrm{HOTf}$ showing atom labeling scheme........................... S32

Figure S57. Solid state structure of Cu6 showing atom labeling scheme....................................... S33

Table S2. Crystal data, intensity collections, and structure parameters for $\mathbf{6} \cdot \mathbf{H C l} \cdot \mathbf{2 H O T f}$ and $\mathbf{C u 6} \ldots$...S33 
Table S3. Computational details of ligands 1-8 modeled using the B3LYP 6-31++G(d,p) basis set. .. S34

Table S4. Computational details for 1 using B3LYP 6-31++G(d,p) basis set. ................................. S34

Table S5. Computational details for 2a using B3LYP 6-31++G(d,p) basis set. ...............................S35

Table S6. Computational details for 5 using B3LYP 6-31++G(d,p) basis set. .................................. S36

Table S7. Computational details for 6 using B3LYP 6-31++G(d,p) basis set. ..................................S37

Table S8. Computational details for 7 using B3LYP 6-31++G(d,p) basis set. .................................. S38

Table S9. Computational details for 8 using B3LYP 6-31++G(d,p) basis set. .................................S39 


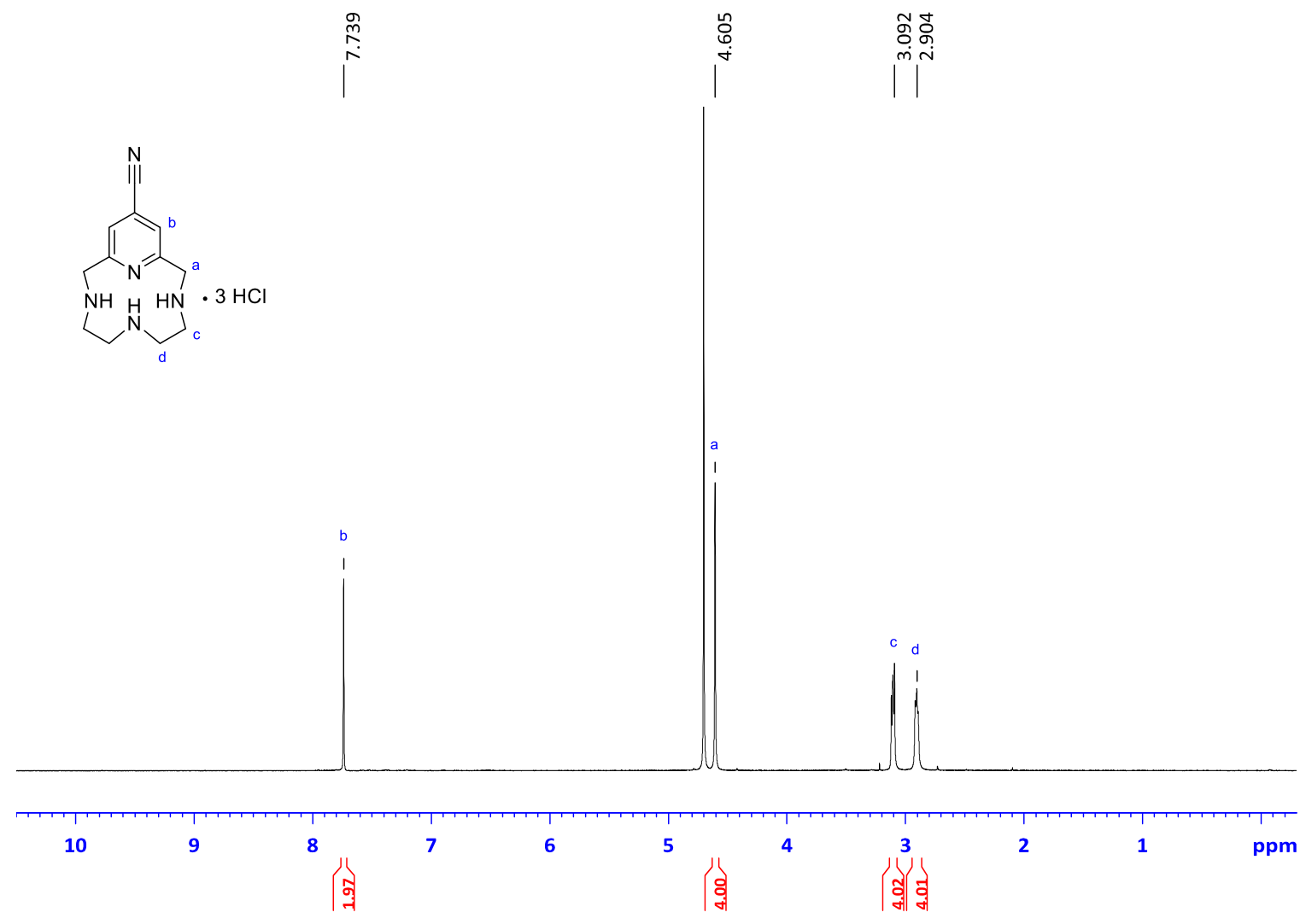

Figure S1. ${ }^{1} \mathrm{H}(400 \mathrm{MHz}) \mathrm{NMR}$ spectrum of $\mathbf{5} \cdot \mathbf{3 H C l}$ in $\mathrm{D}_{2} \mathrm{O}$.

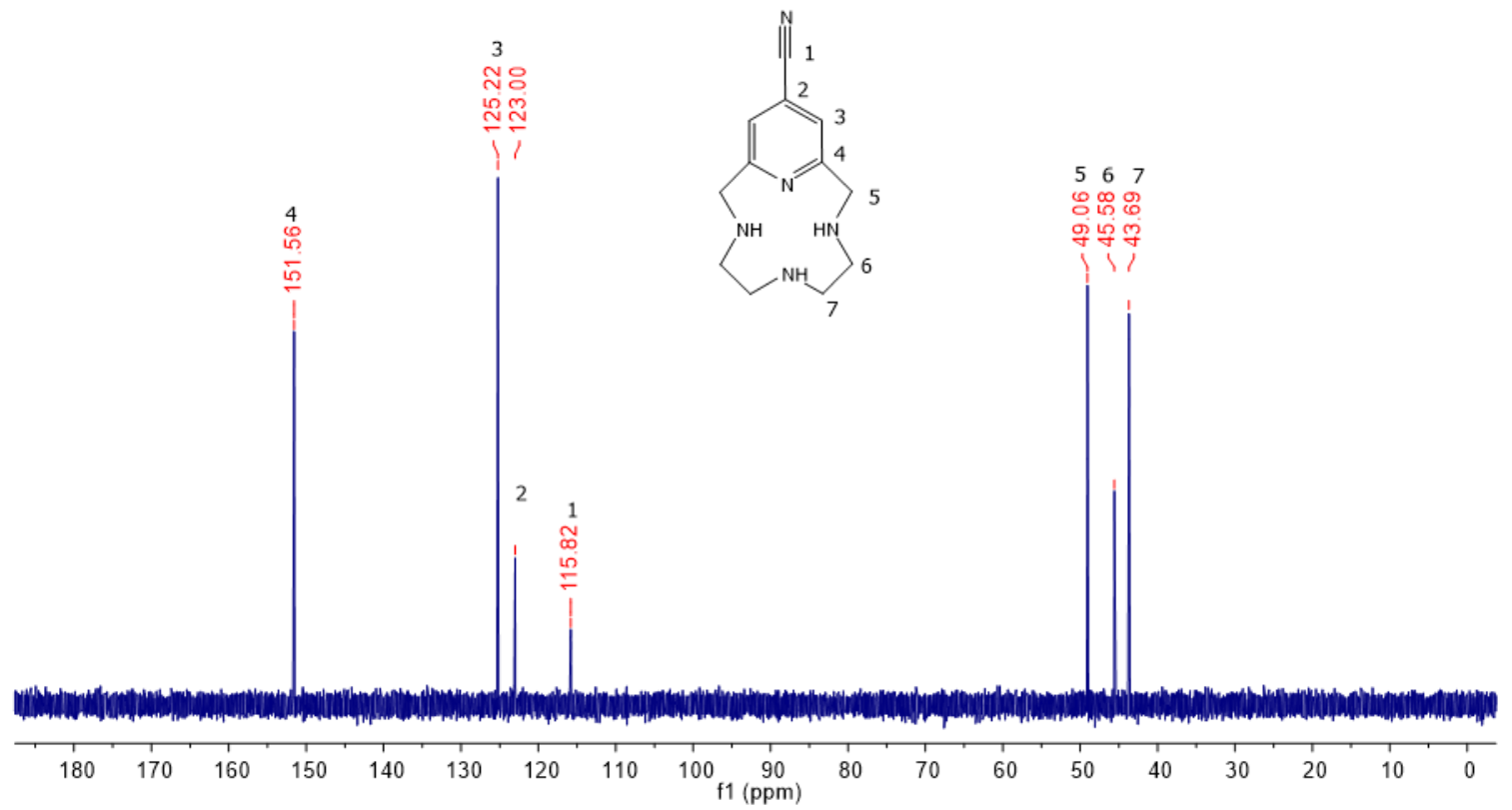

Figure S2. ${ }^{13} \mathrm{C}\left\{{ }^{1} \mathrm{H}\right\}(101 \mathrm{MHz}) \mathrm{NMR}$ spectrum of $\mathbf{5} \cdot \mathbf{3 H C l}$ in $\mathrm{D}_{2} \mathrm{O}$. 


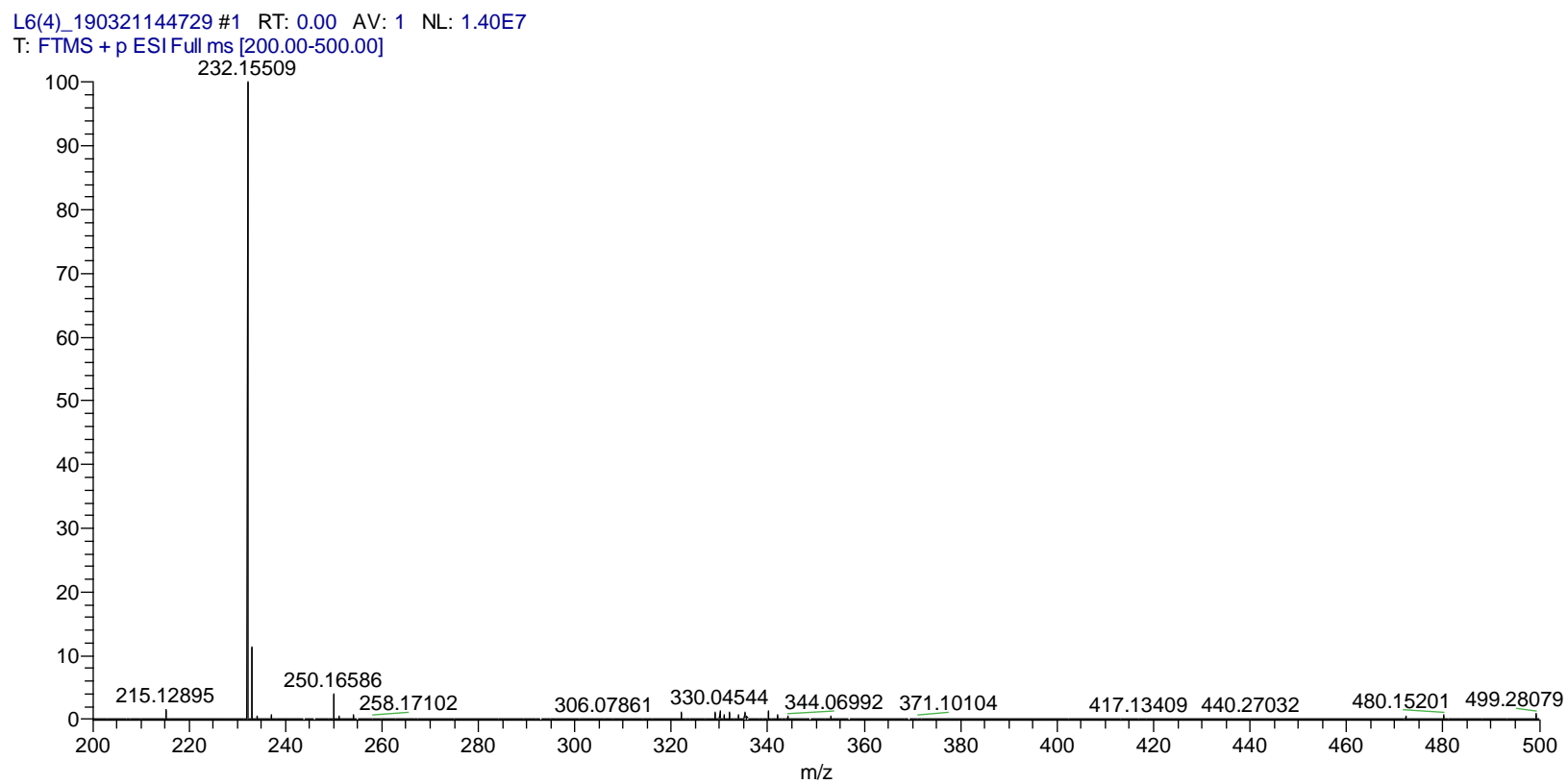

Figure S3. HR-MS spectrum of $\mathbf{5} \cdot \mathbf{3 H C l}$.

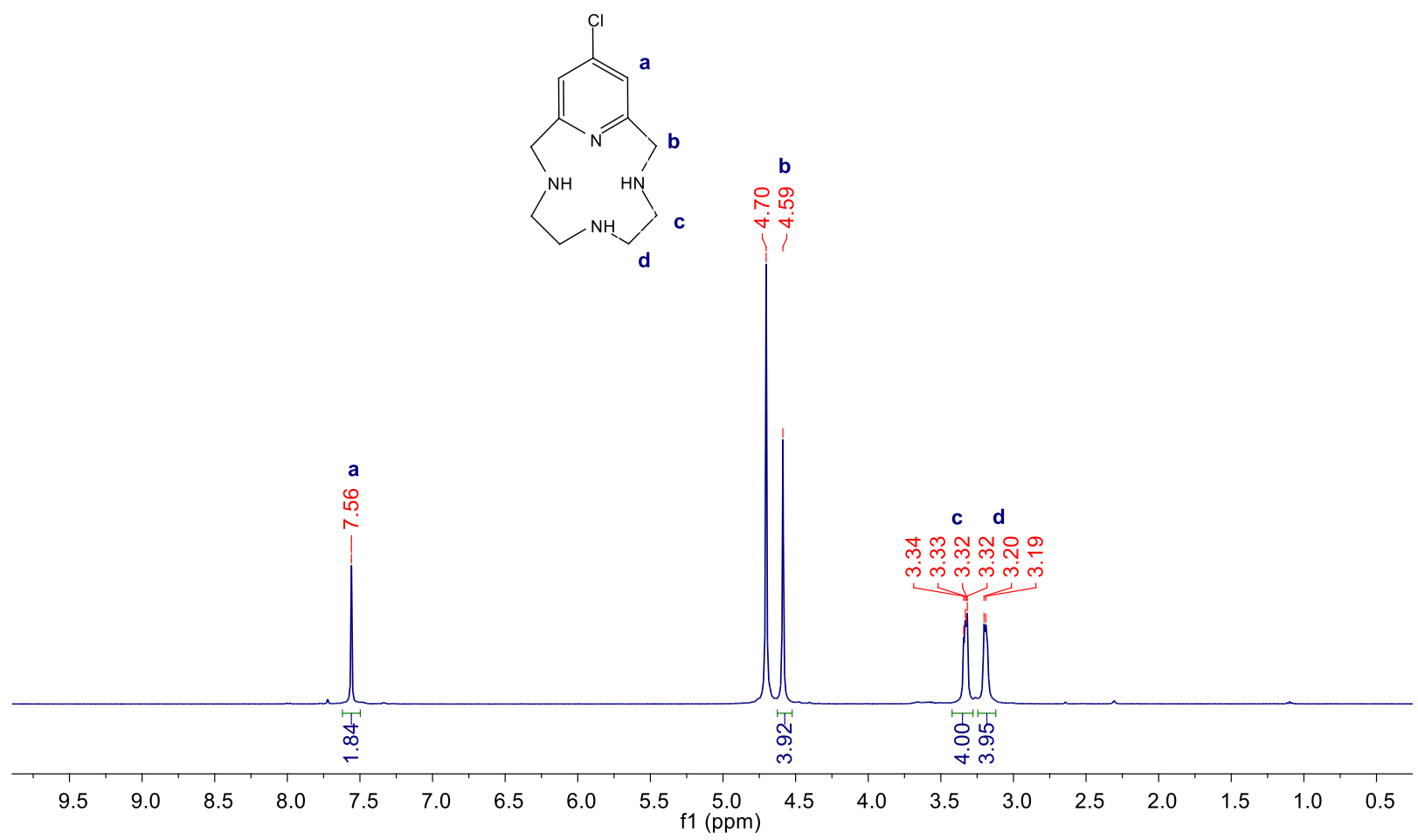

Figure S4. ${ }^{1} \mathrm{H}(400 \mathrm{MHz}) \mathrm{NMR}$ spectrum of $\mathbf{6} \cdot \mathbf{3 H C l}$ in $\mathrm{D}_{2} \mathrm{O}$. 


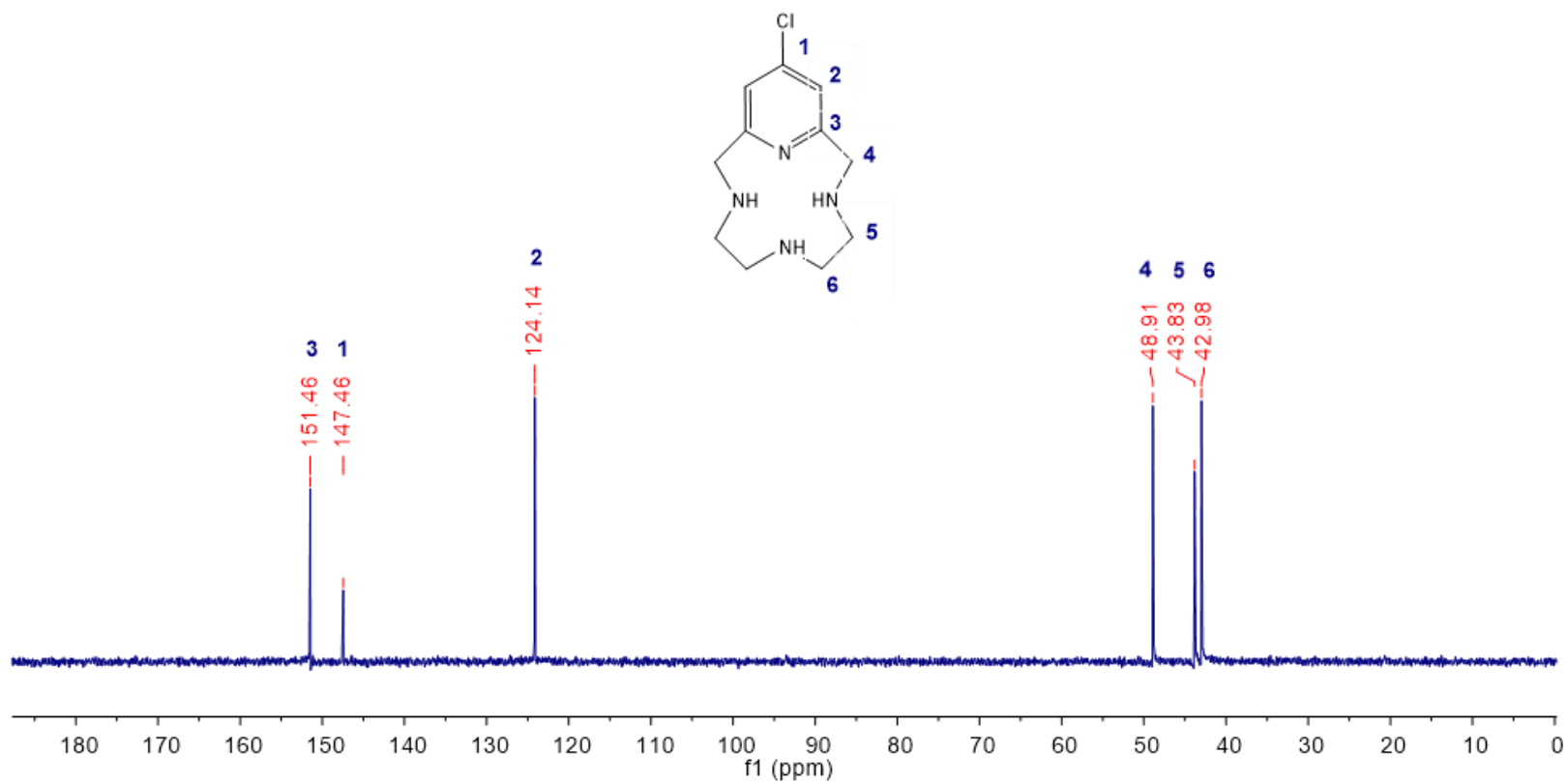

Figure S5. ${ }^{13} \mathrm{C}\left\{{ }^{1} \mathrm{H}\right\}(101 \mathrm{MHz}) \mathrm{NMR}$ spectrum of $\mathbf{6} \cdot \mathbf{3 H C l}$ in $\mathrm{D}_{2} \mathrm{O}$.

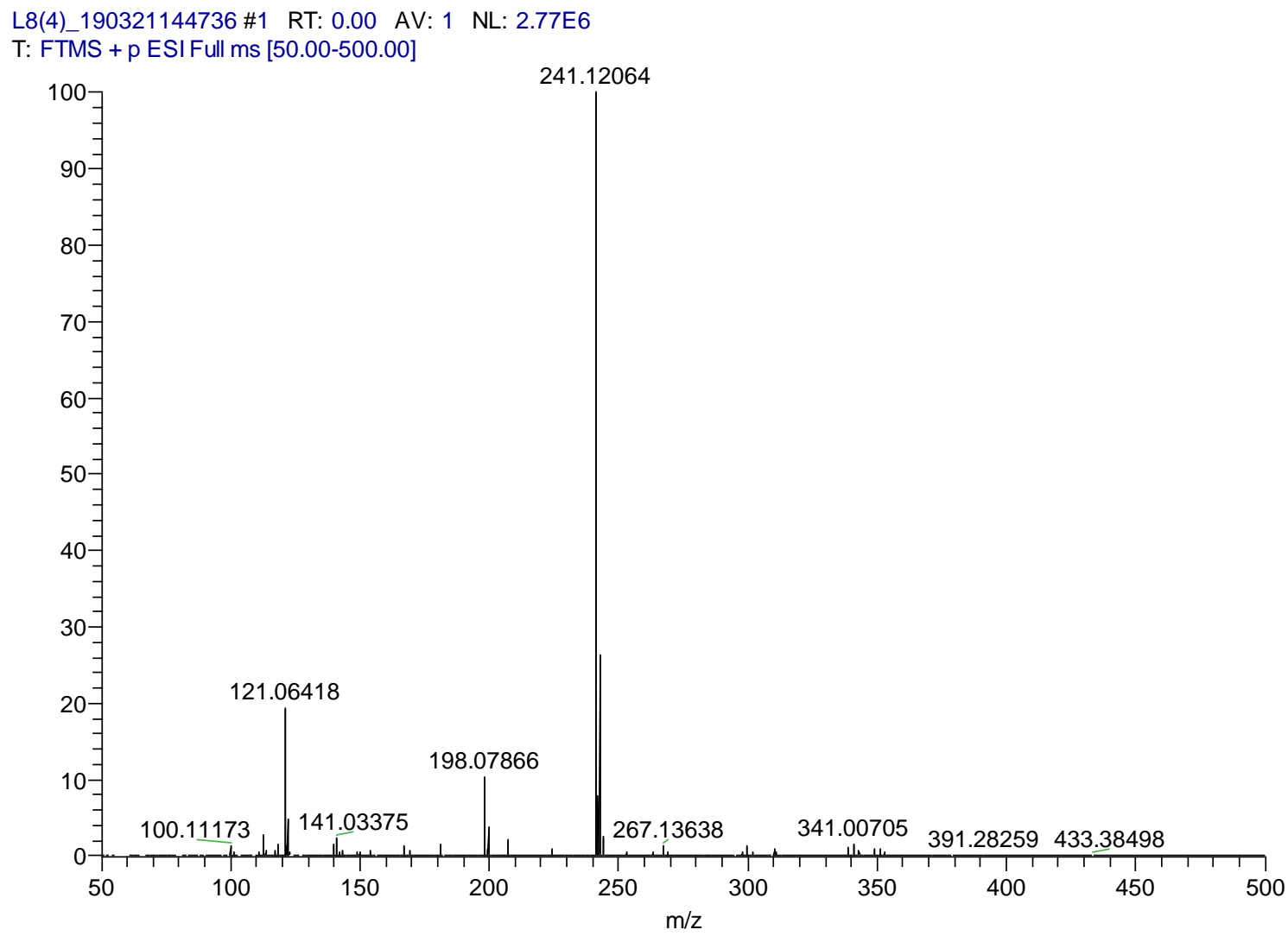

Figure S6. HR-MS spectrum of $\mathbf{6} \cdot \mathbf{3 H C l}$. 


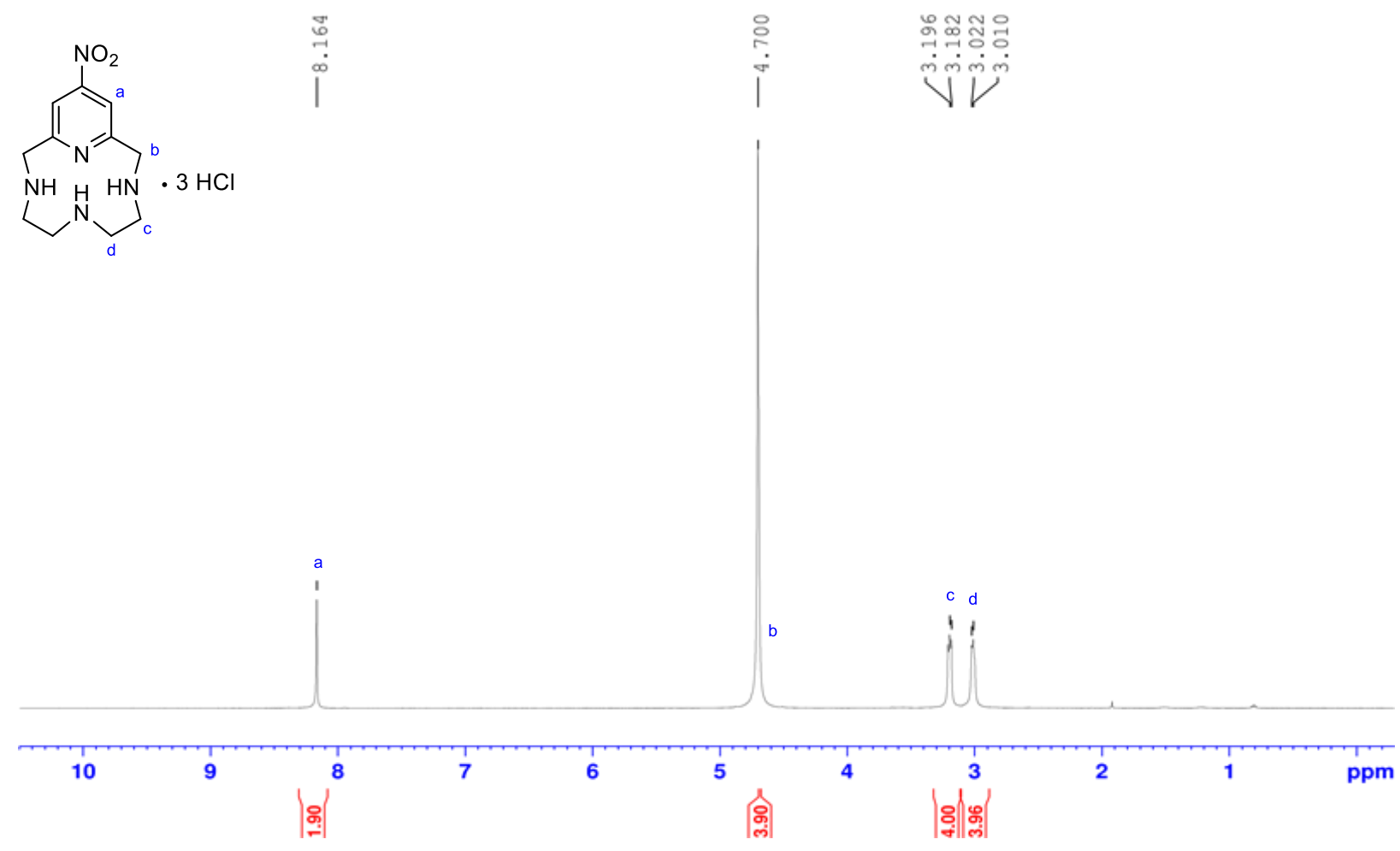

Figure S7. ${ }^{1} \mathrm{H}(400 \mathrm{MHz}) \mathrm{NMR}$ spectrum of $\mathbf{7 \cdot 3 H C l}$ in $\mathrm{D}_{2} \mathrm{O}$.

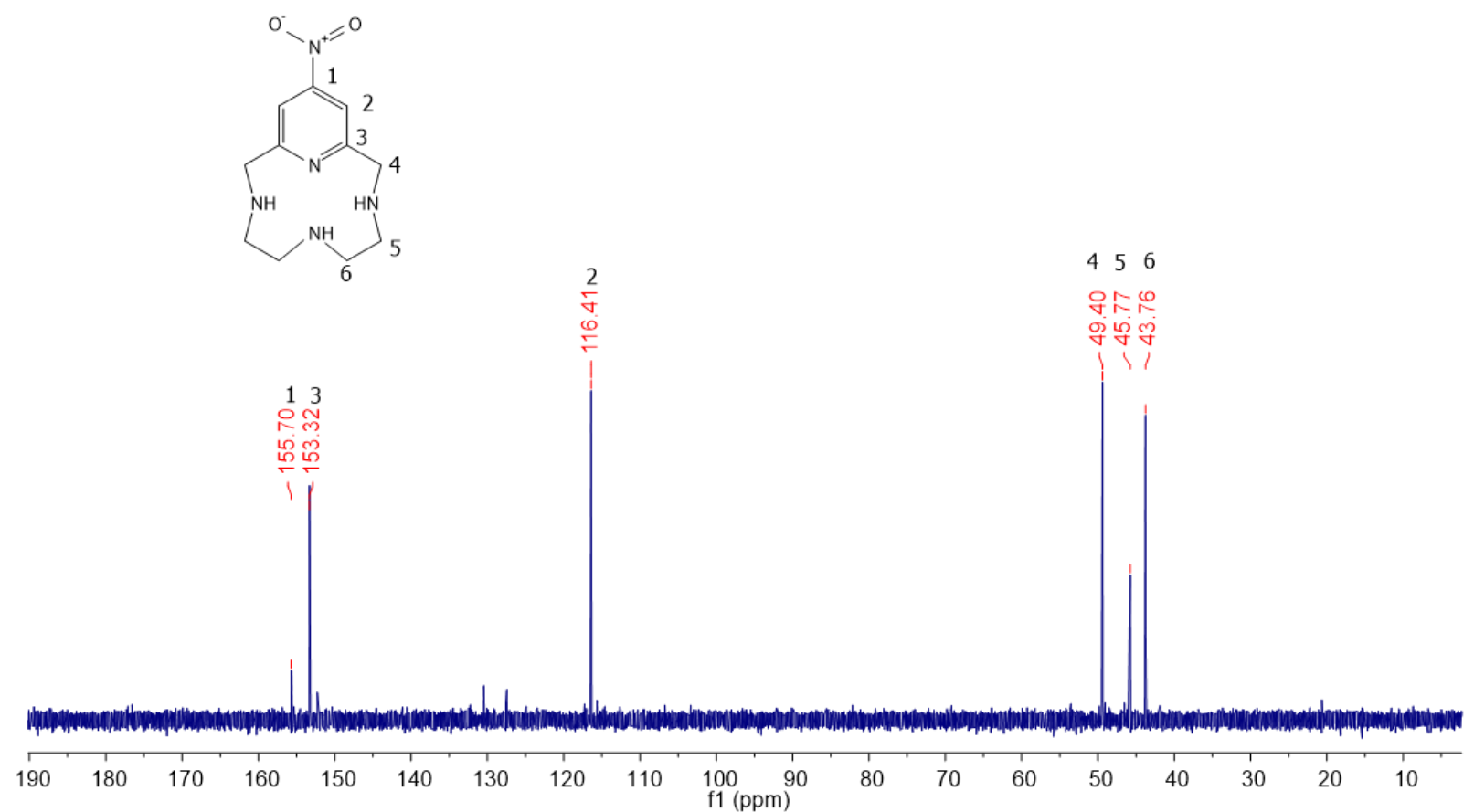

Figure S8. ${ }^{13} \mathrm{C}\left\{{ }^{1} \mathrm{H}\right\}(101 \mathrm{MHz})$ NMR spectrum of $\mathbf{7 \cdot 3 H C l}$ in $\mathrm{D}_{2} \mathrm{O}$. 


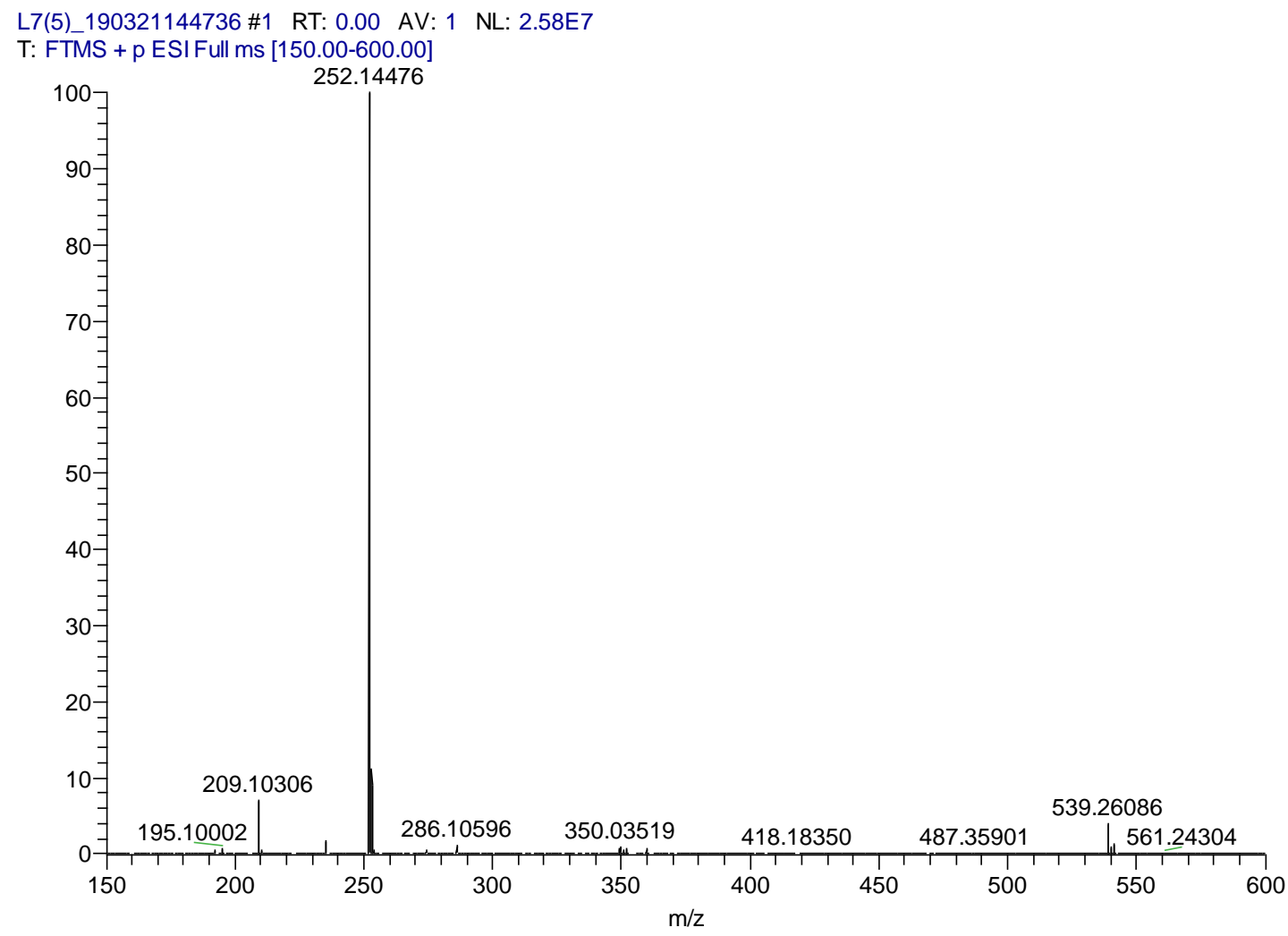

Figure S9. HR-MS spectrum of $\mathbf{7} \cdot \mathbf{3 H C l}$.

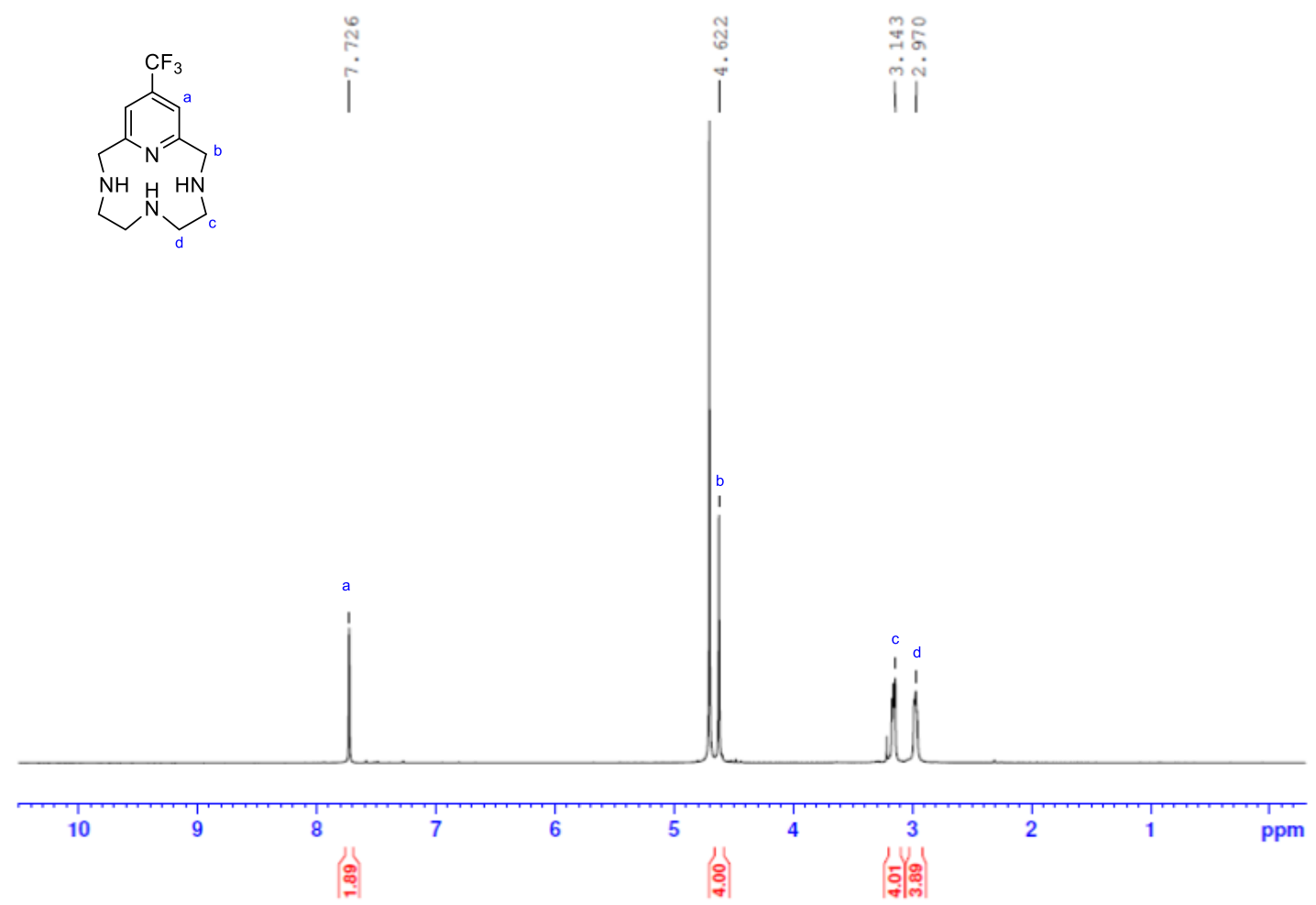

Figure S10. ${ }^{1} \mathrm{H}(400 \mathrm{MHz}) \mathrm{NMR}$ spectrum of $\mathbf{8} \cdot \mathbf{3 H C l}$ in $\mathrm{D}_{2} \mathrm{O}$. 


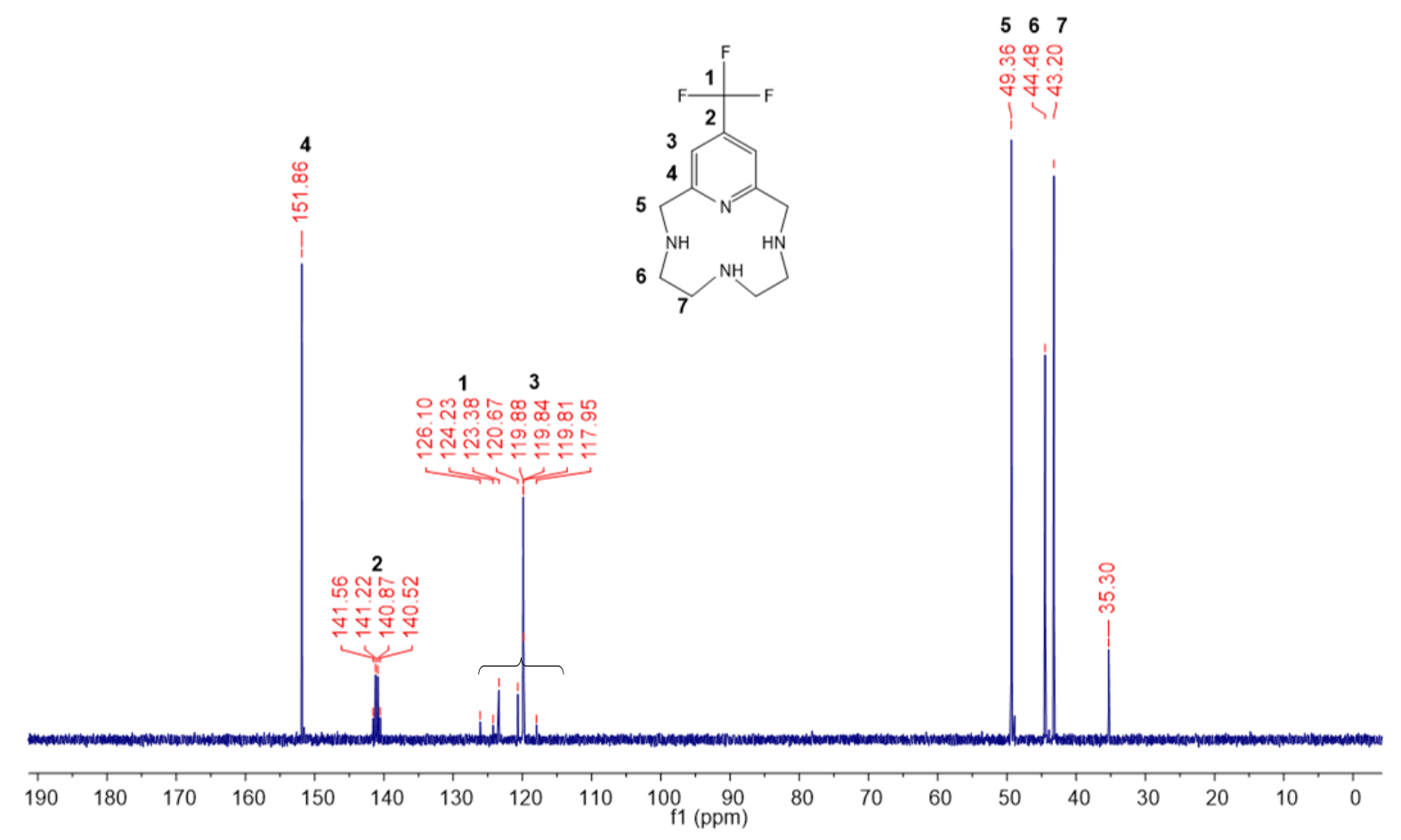

Figure S11. ${ }^{13} \mathrm{C}\left\{{ }^{1} \mathrm{H}\right\}(101 \mathrm{MHz}) \mathrm{NMR}$ spectrum of $\mathbf{8} \cdot \mathbf{3 H C l}$ in $\mathrm{D}_{2} \mathrm{O}$.

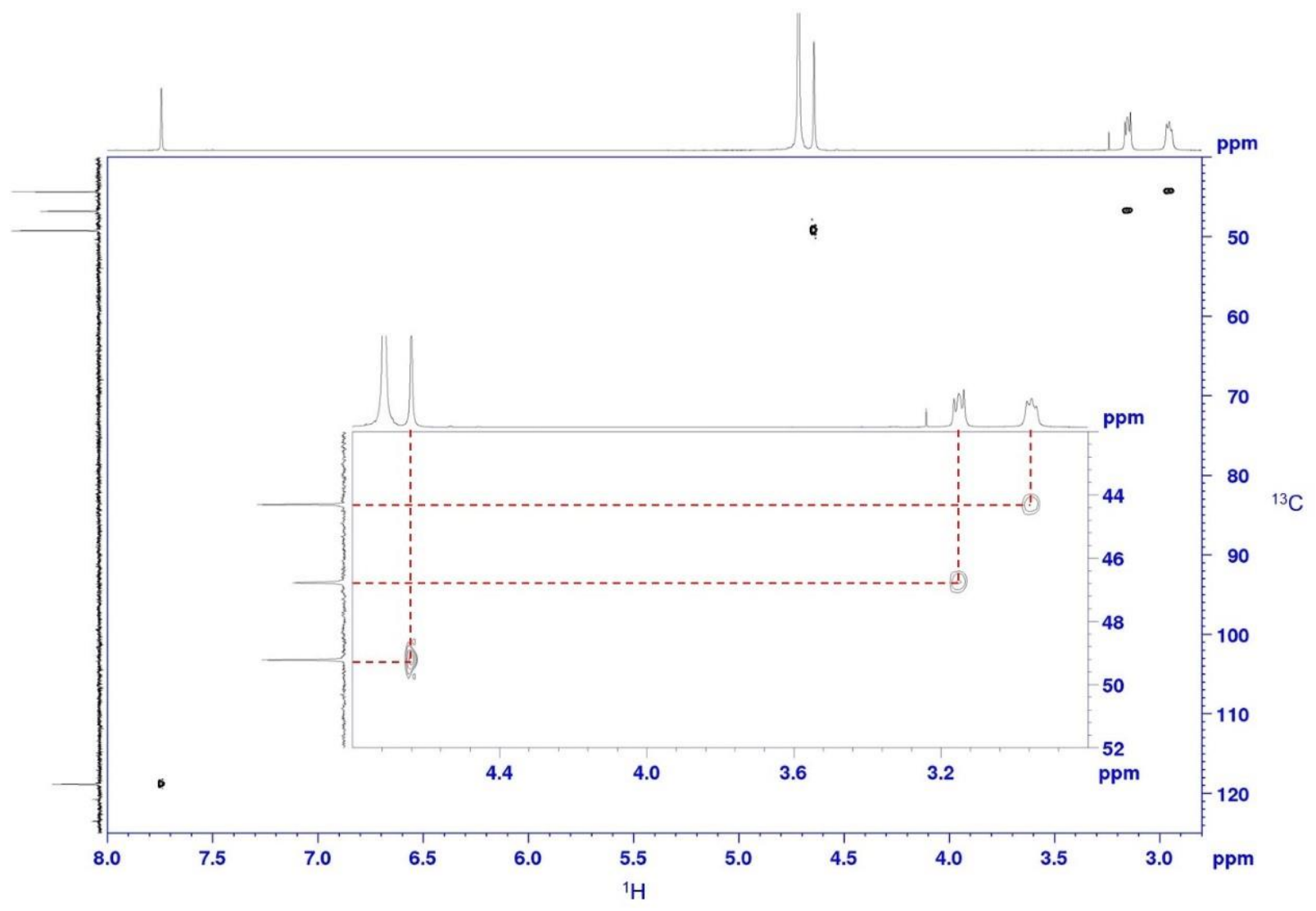

Figure S12. ${ }^{1} \mathrm{H}_{-}{ }^{13} \mathrm{C}$ HSQC NMR spectrum of $\mathbf{8} \cdot \mathbf{3 H C l}$ in $\mathrm{D}_{2} \mathrm{O}$. 


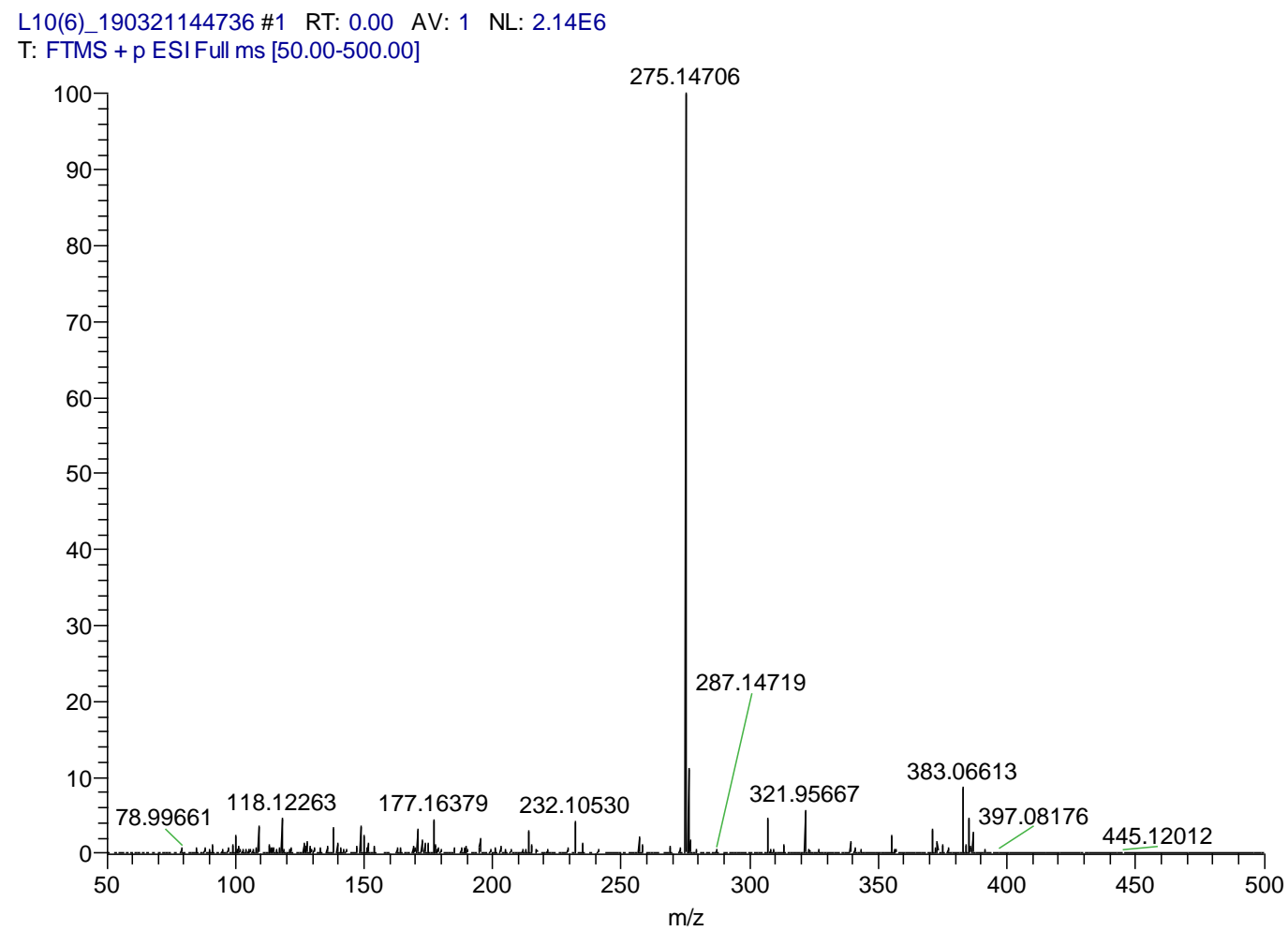

Figure S13. HR-MS spectrum of $\mathbf{8} \cdot \mathbf{3 H C l}$.

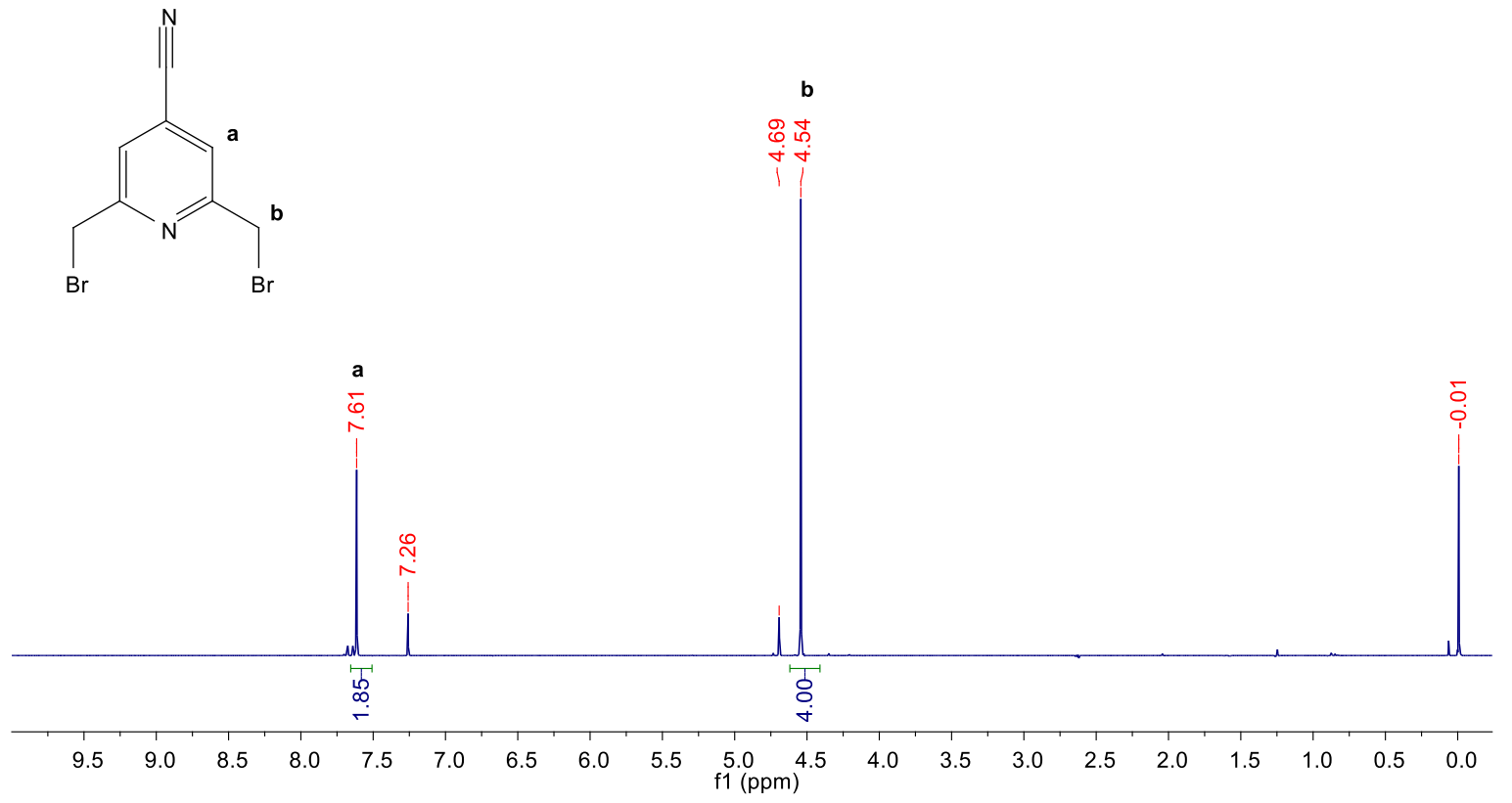

Figure S14. ${ }^{1} \mathrm{H}(400 \mathrm{MHz}) \mathrm{NMR}$ spectrum of 9 in $\mathrm{CDCl}_{3}$. 


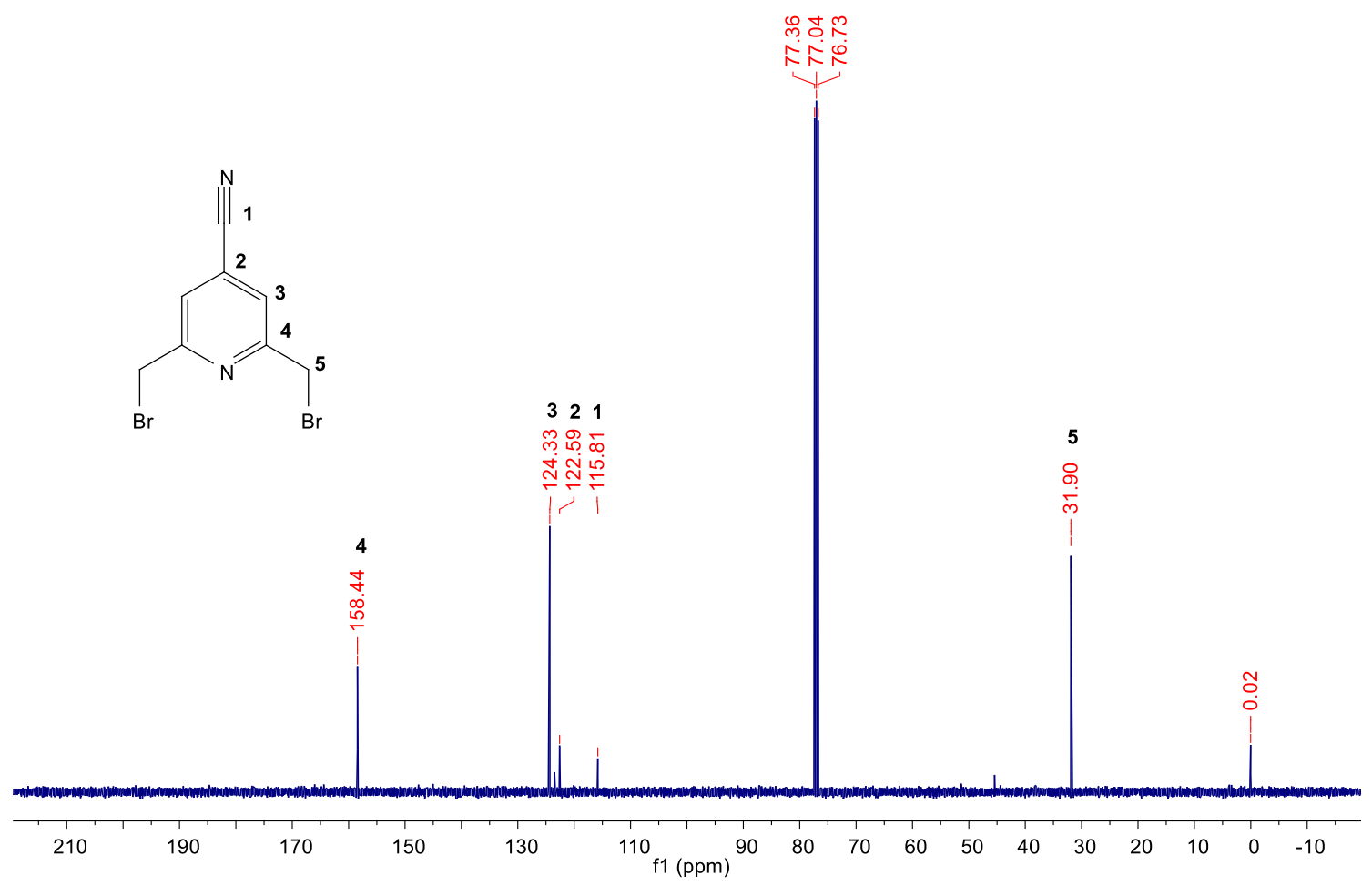

Figure S15. ${ }^{13} \mathrm{C}\left\{{ }^{1} \mathrm{H}\right\}(101 \mathrm{MHz})$ NMR spectrum of 9 in $\mathrm{CDCl}_{3}$.

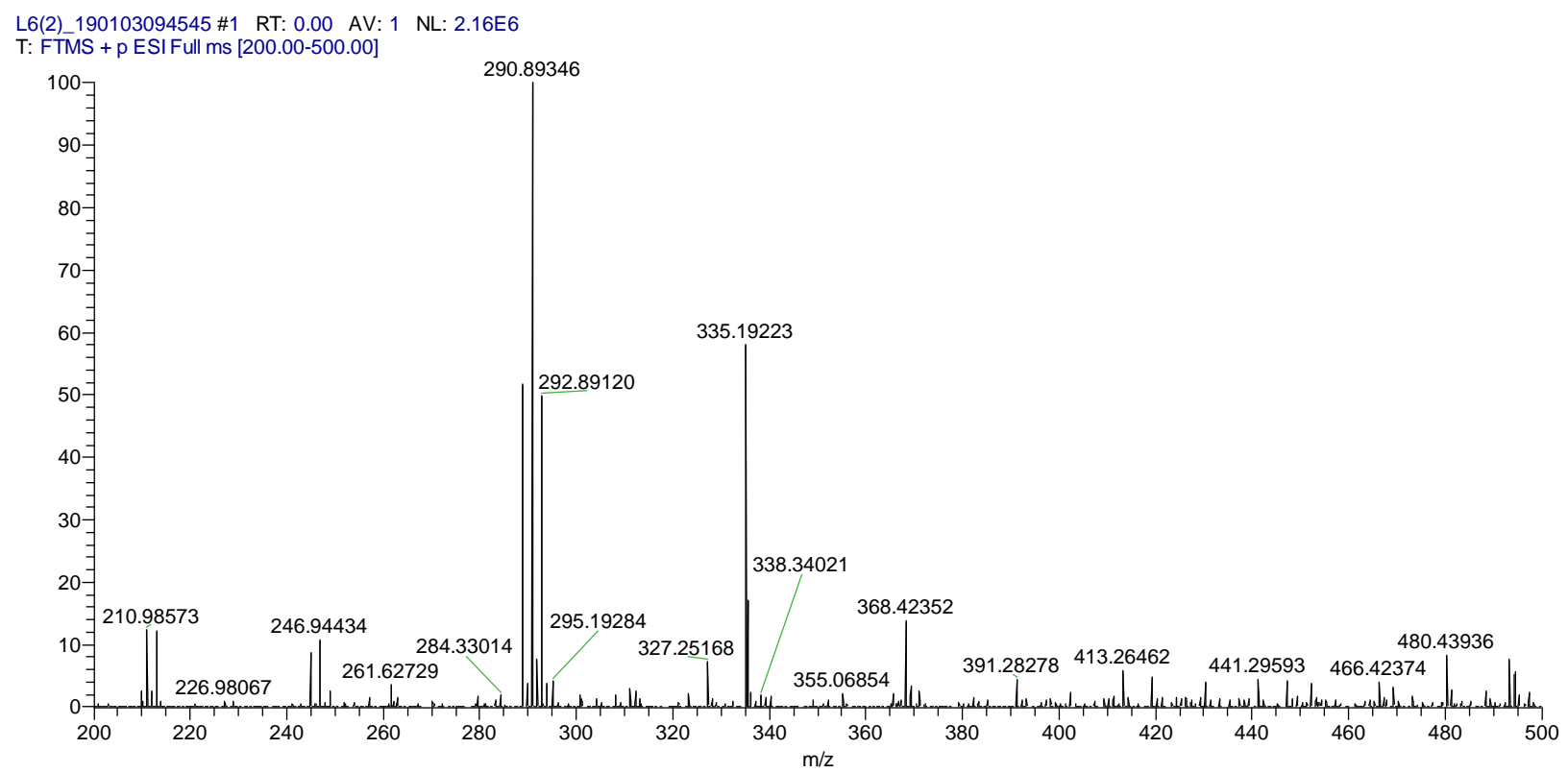

Figure S16. HR-MS spectrum of 9. 


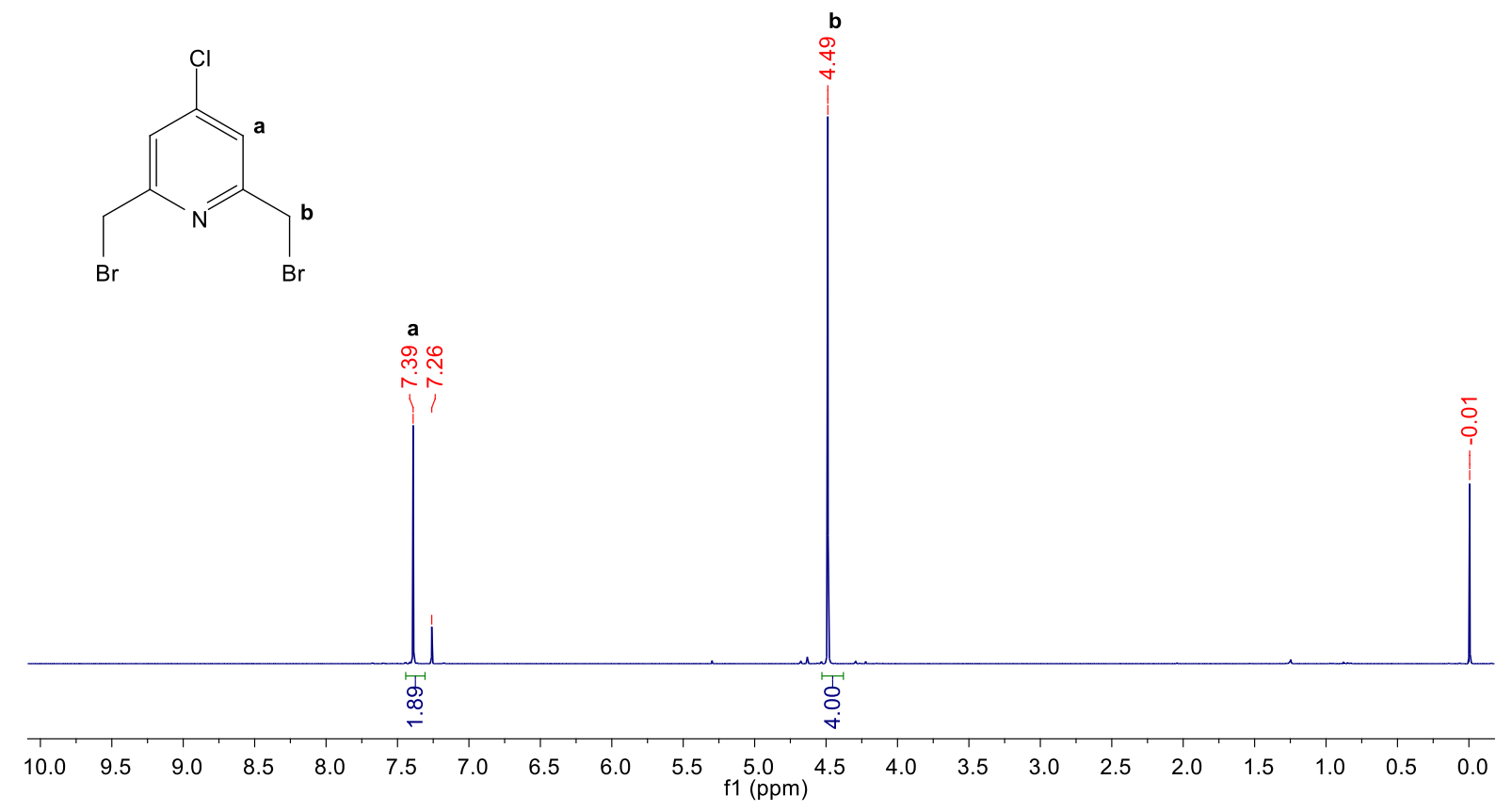

Figure S17. ${ }^{1} \mathrm{H}(400 \mathrm{MHz}) \mathrm{NMR}$ spectrum of $\mathbf{1 0}$ in $\mathrm{CDCl}_{3}$.

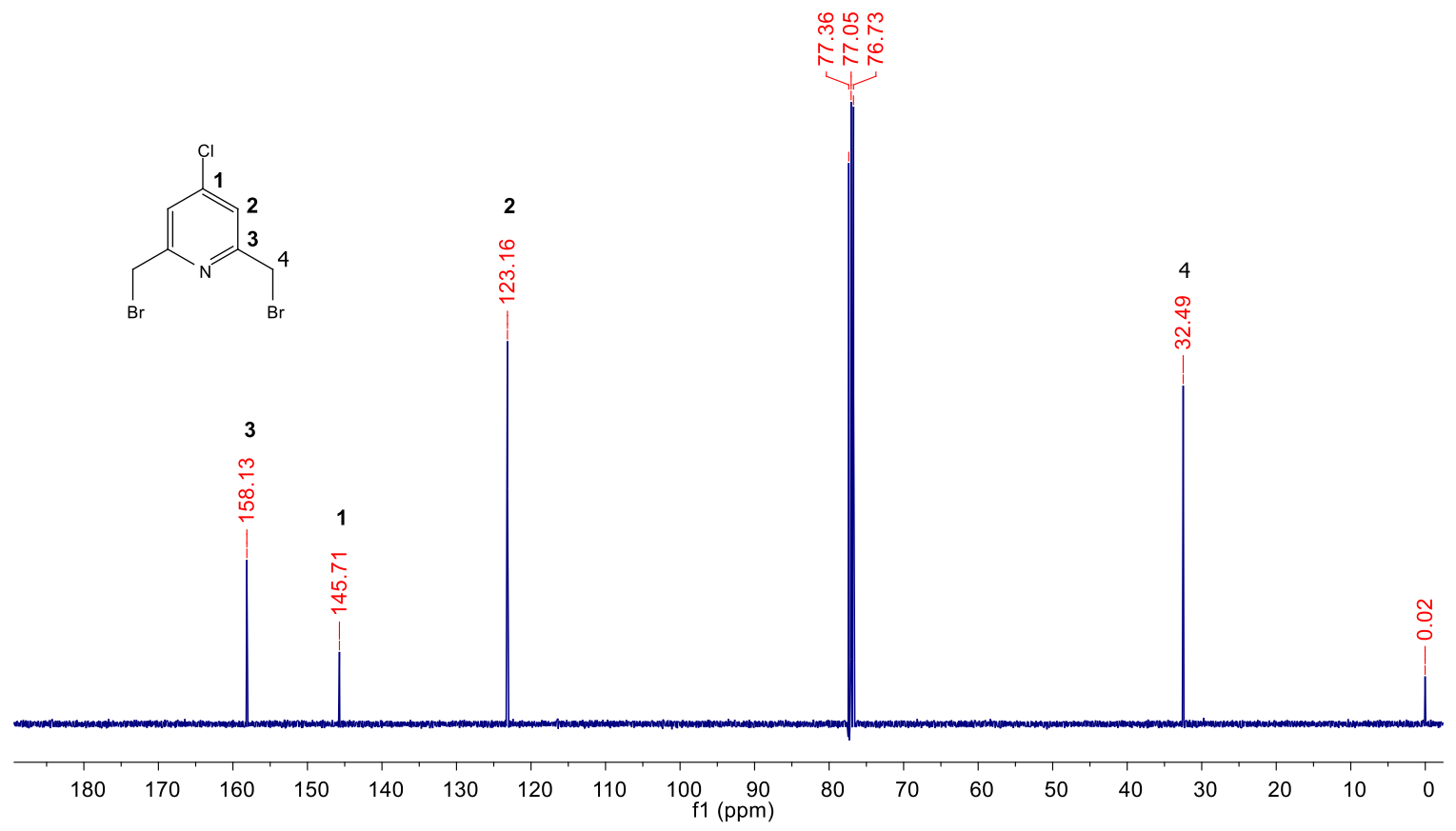

Figure S18. ${ }^{13} \mathrm{C}\left\{{ }^{1} \mathrm{H}\right\}(101 \mathrm{MHz}) \mathrm{NMR}$ spectrum of $\mathbf{1 0}$ in $\mathrm{CDCl}_{3}$. 
L8(2)_190321144736 \#1 RT: 0.00 AV: 1 NL: $3.41 E 6$

T: FTMS + p ESI Full ms [50.00-500.00]

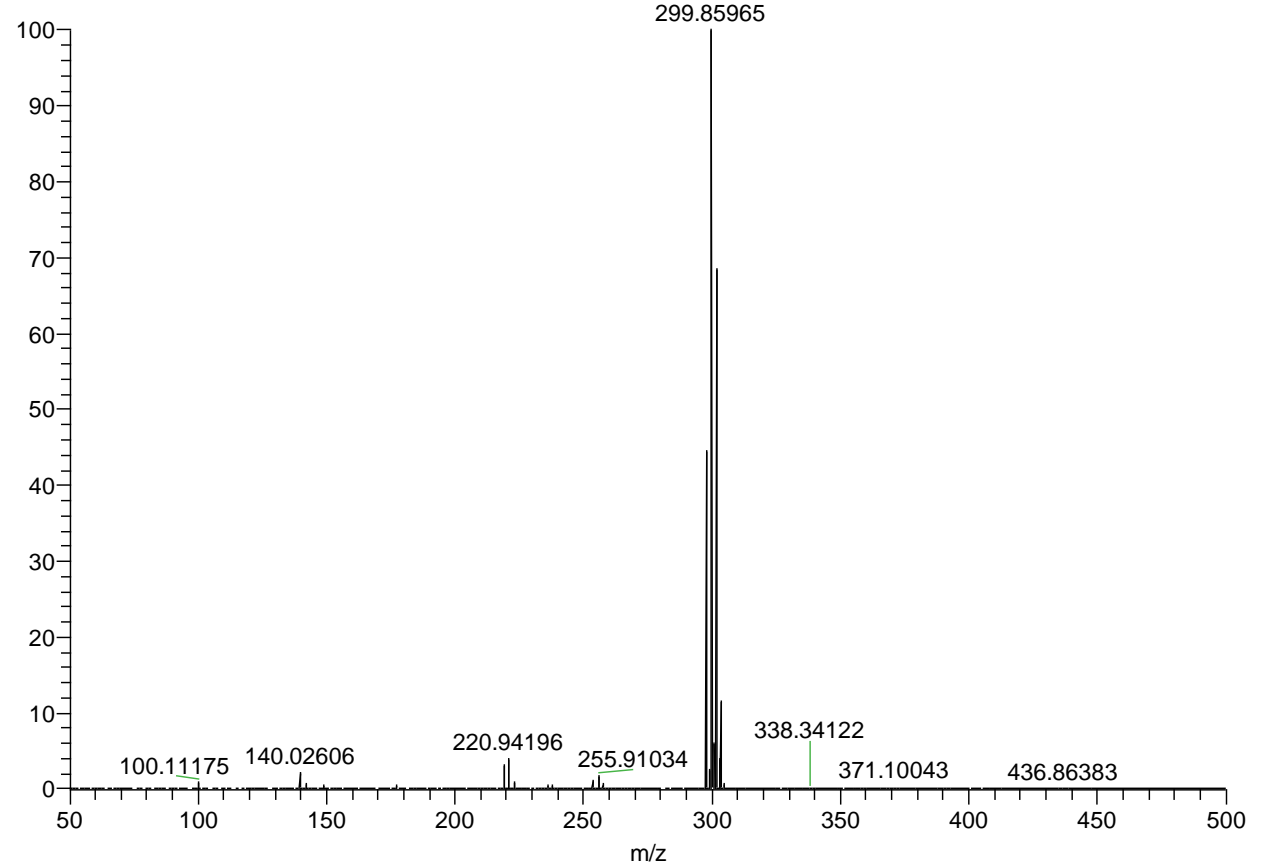

Figure S19. HR-MS spectrum of $\mathbf{1 0 .}$
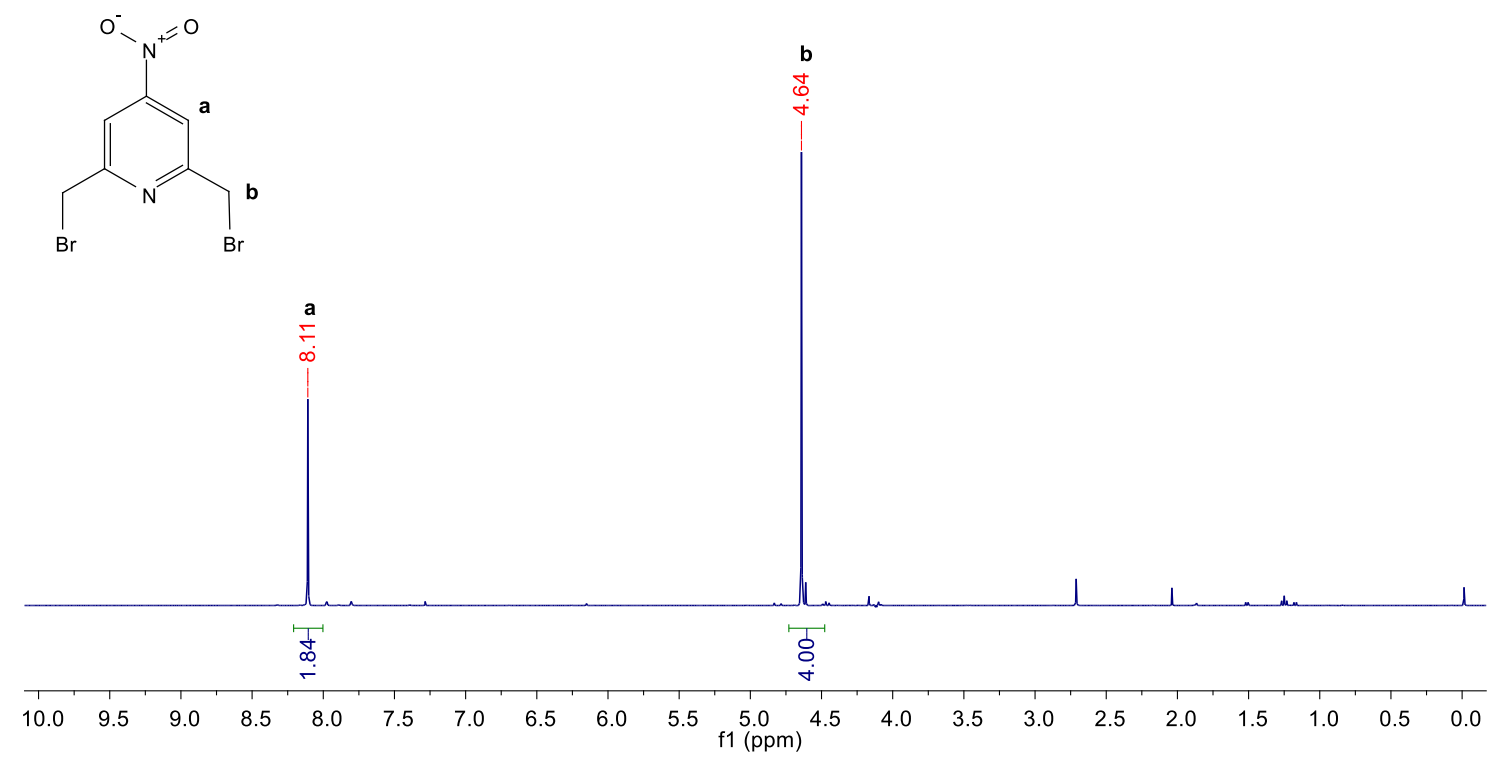

Figure S20. ${ }^{1} \mathrm{H}(400 \mathrm{MHz}) \mathrm{NMR}$ spectrum of 11 in $\mathrm{CDCl}_{3}$. 


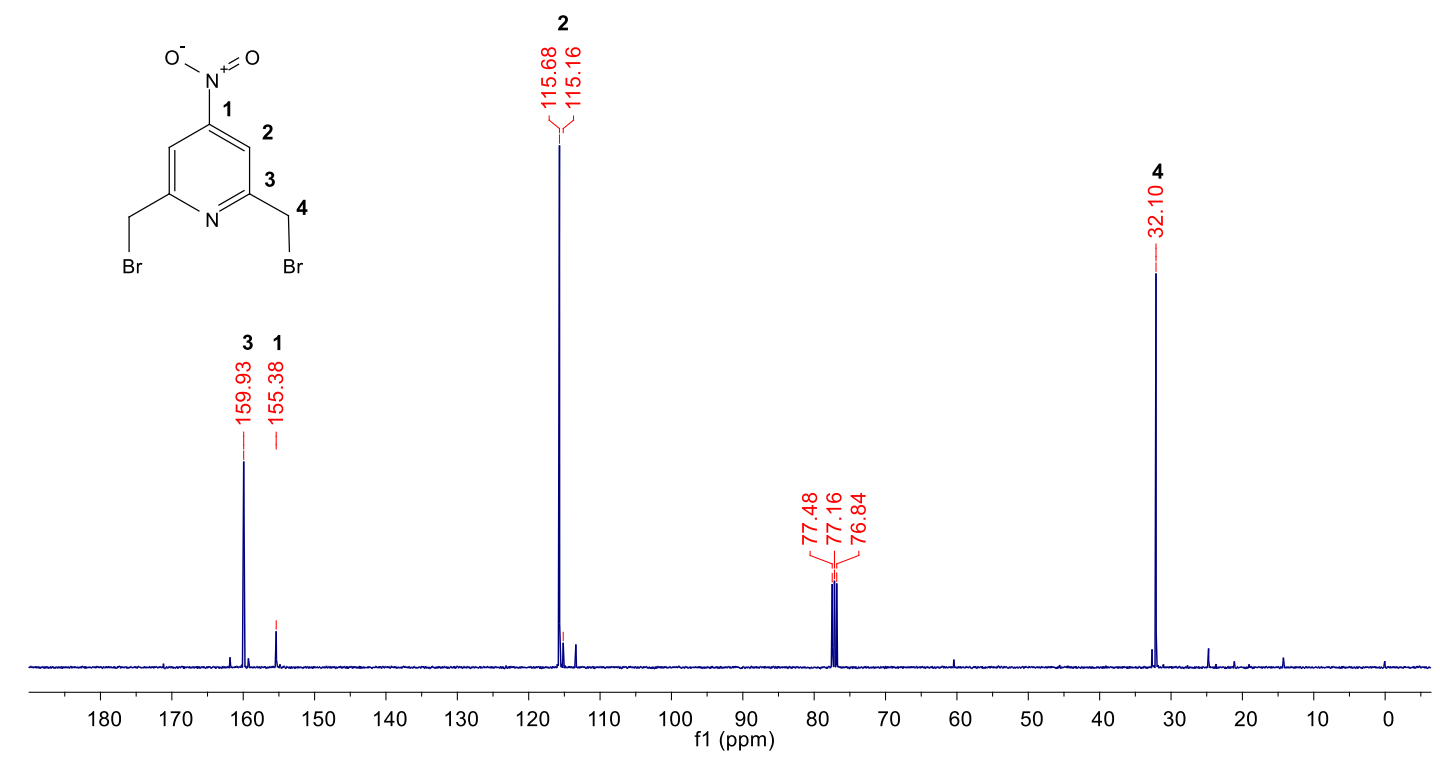

Figure S21. ${ }^{13} \mathrm{C}\left\{{ }^{1} \mathrm{H}\right\}(101 \mathrm{MHz}) \mathrm{NMR}$ spectrum of $\mathbf{1 1}$ in $\mathrm{CDCl}_{3}$.

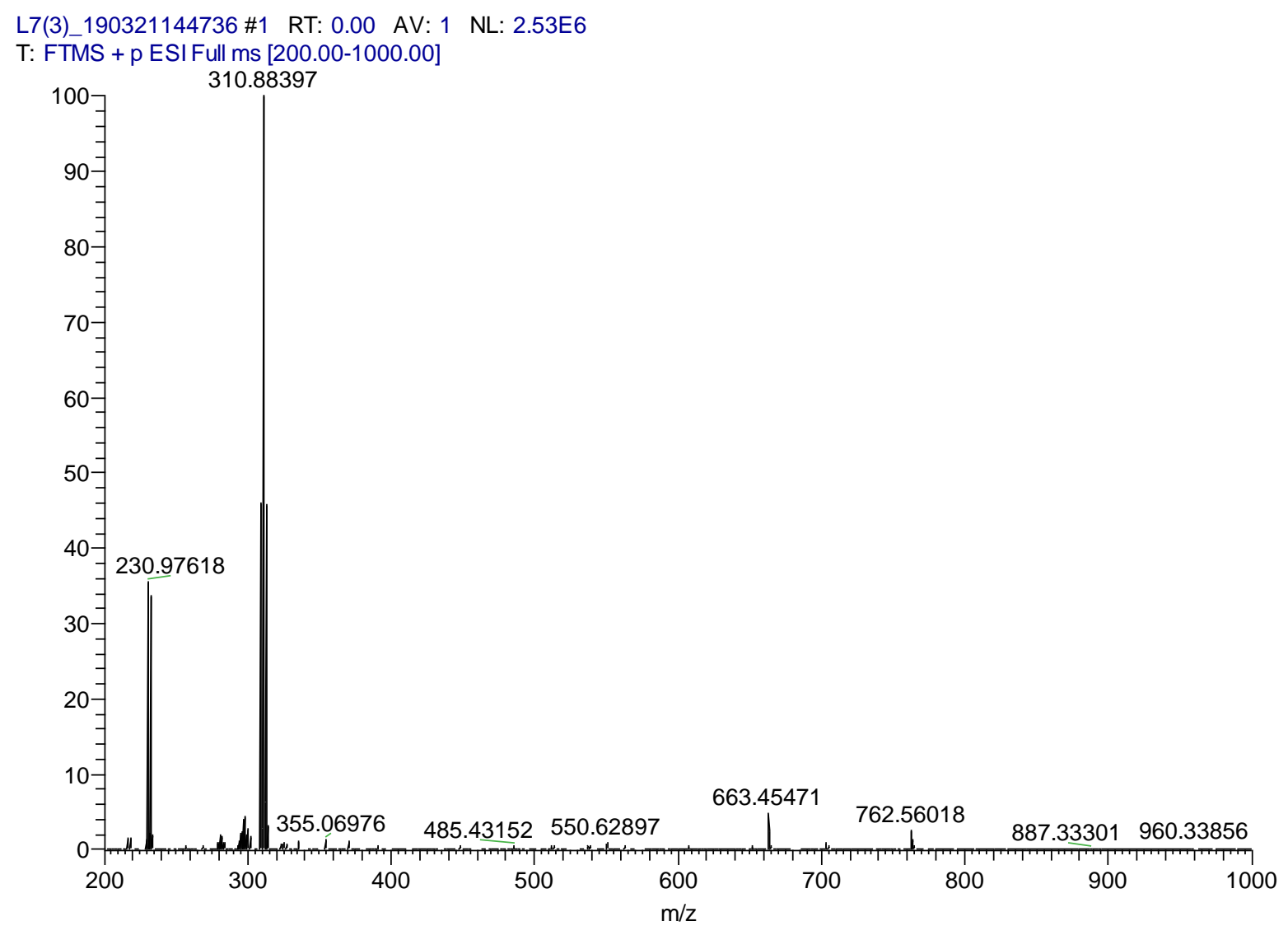

Figure S22. HR-MS spectrum of 11. 


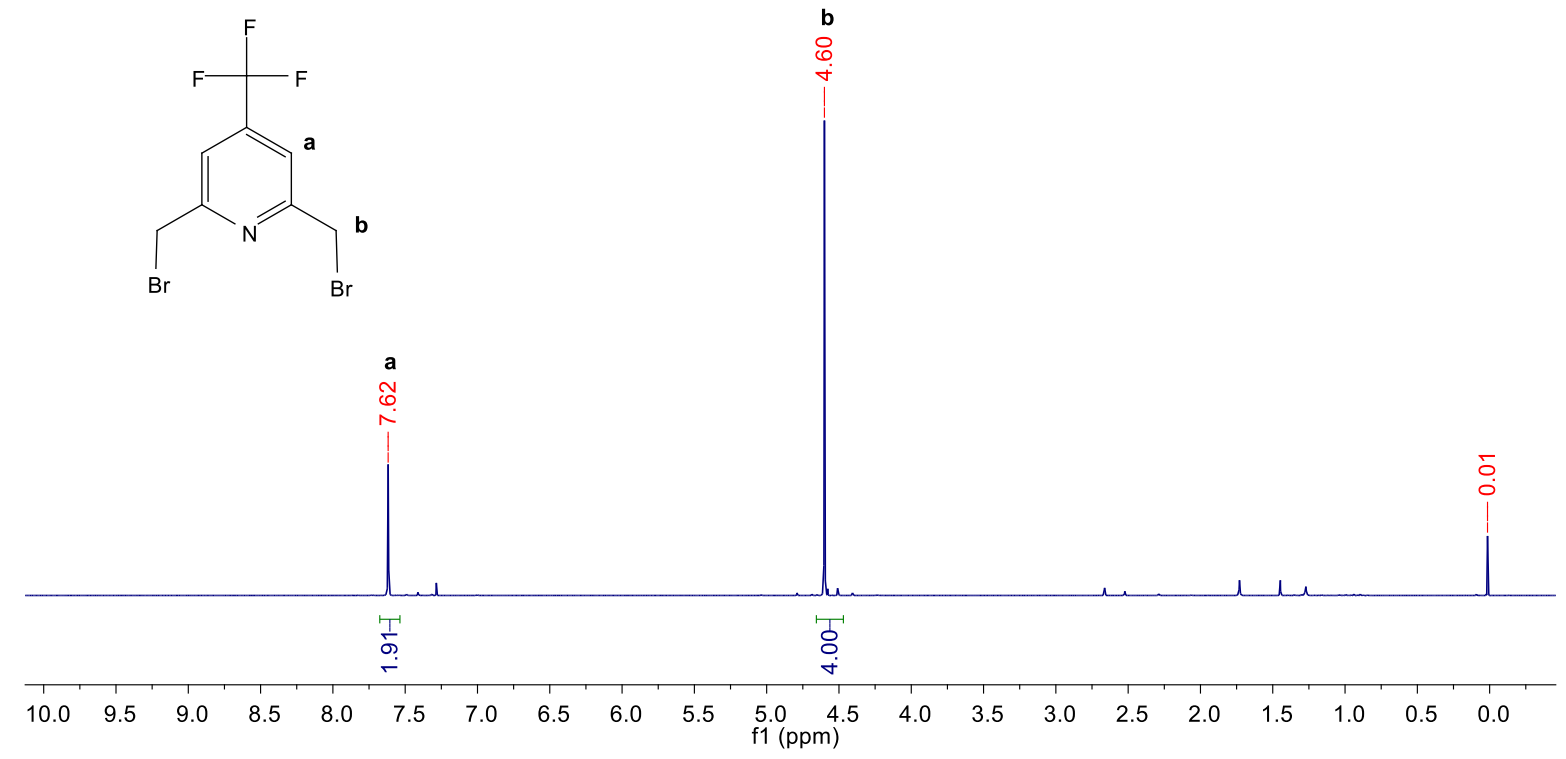

Figure S23. ${ }^{1} \mathrm{H}(400 \mathrm{MHz}) \mathrm{NMR}$ spectrum of 12 in $\mathrm{CDCl}_{3}$.

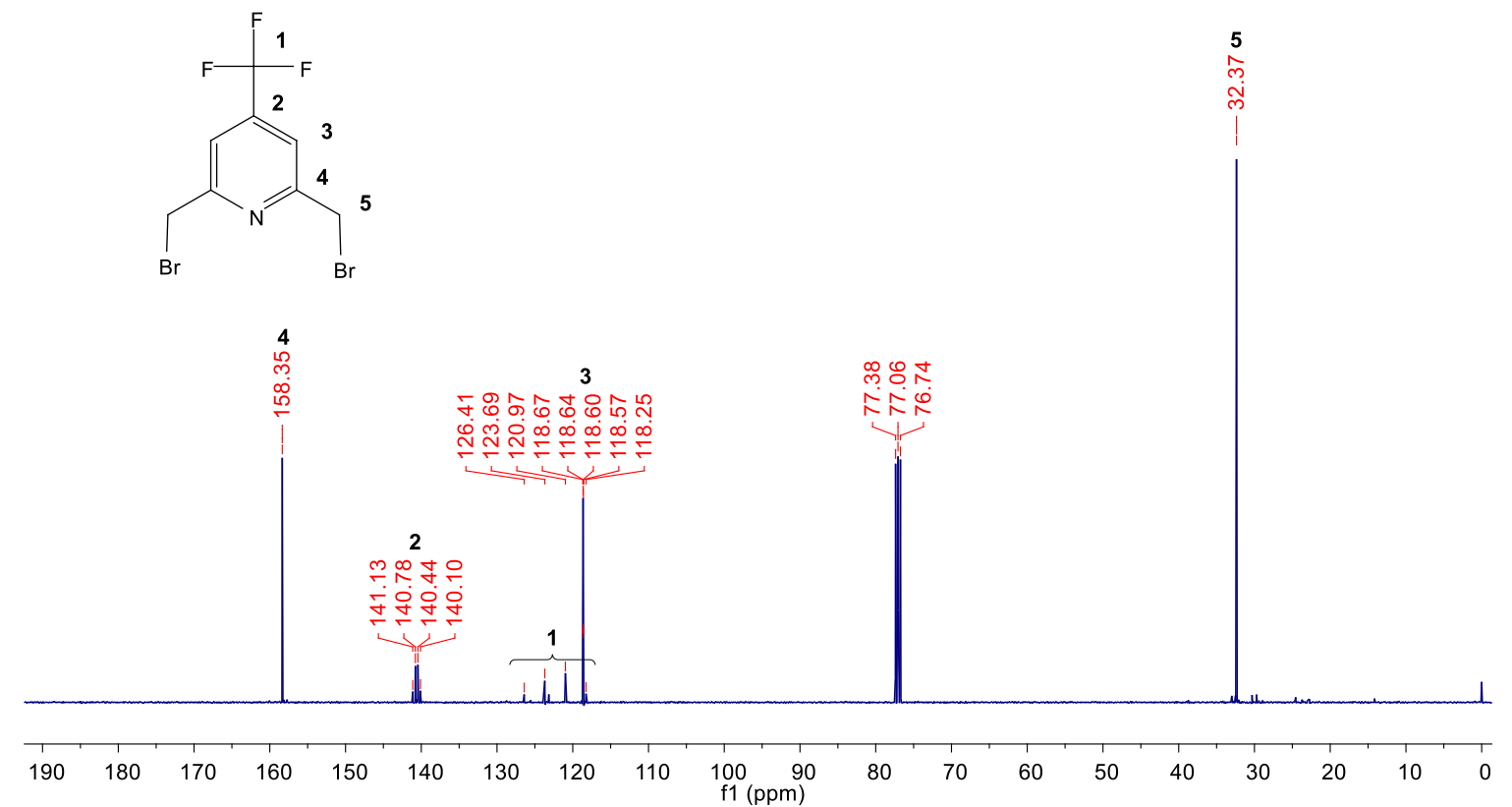

Figure S24. ${ }^{13} \mathrm{C}\left\{{ }^{1} \mathrm{H}\right\}(101 \mathrm{MHz}) \mathrm{NMR}$ spectrum of $\mathbf{1 2}$ in $\mathrm{CDCl}_{3}$. 


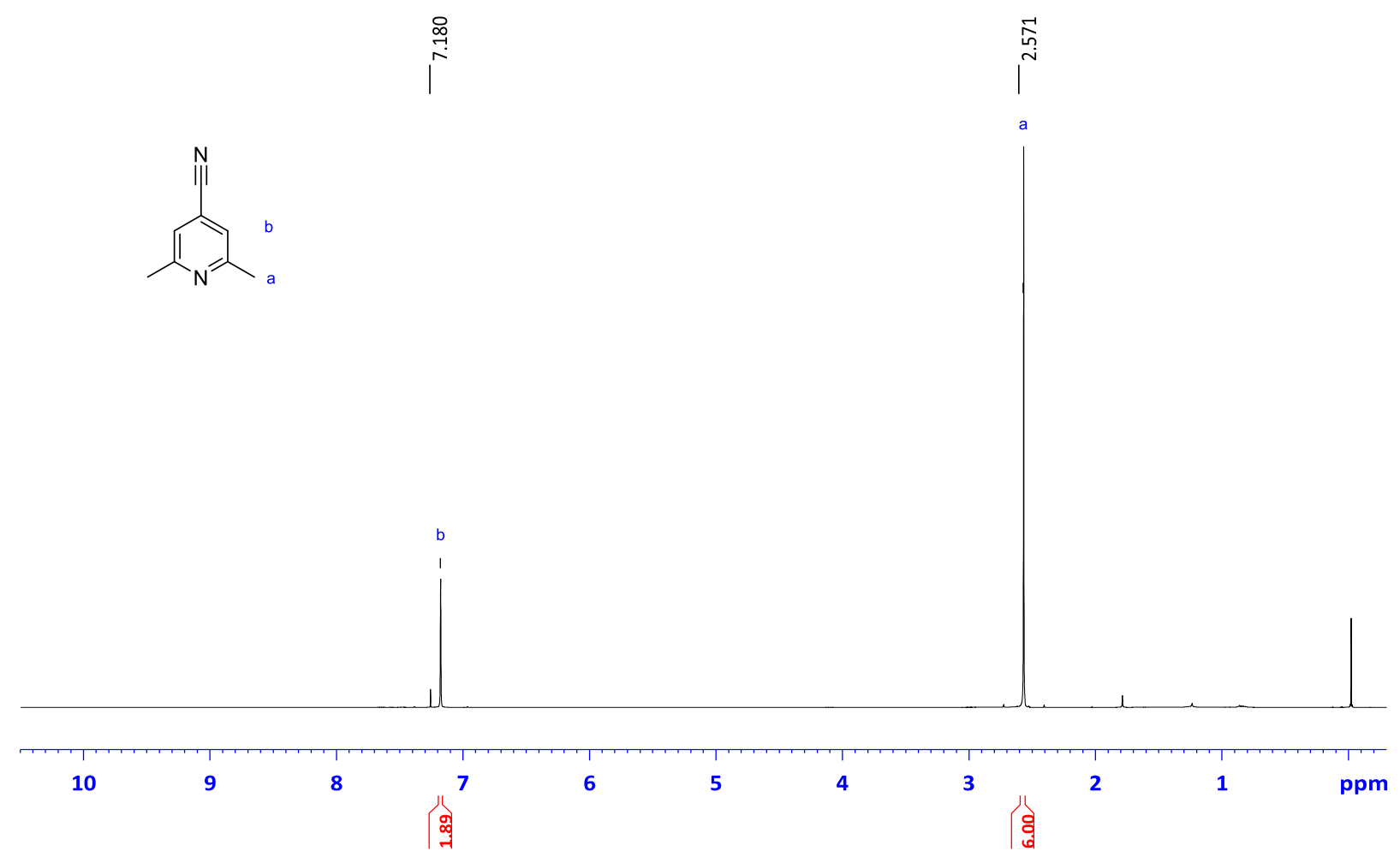

Figure S25. ${ }^{1} \mathrm{H}(400 \mathrm{MHz}) \mathrm{NMR}$ spectrum of 14 in $\mathrm{CDCl}_{3}$.

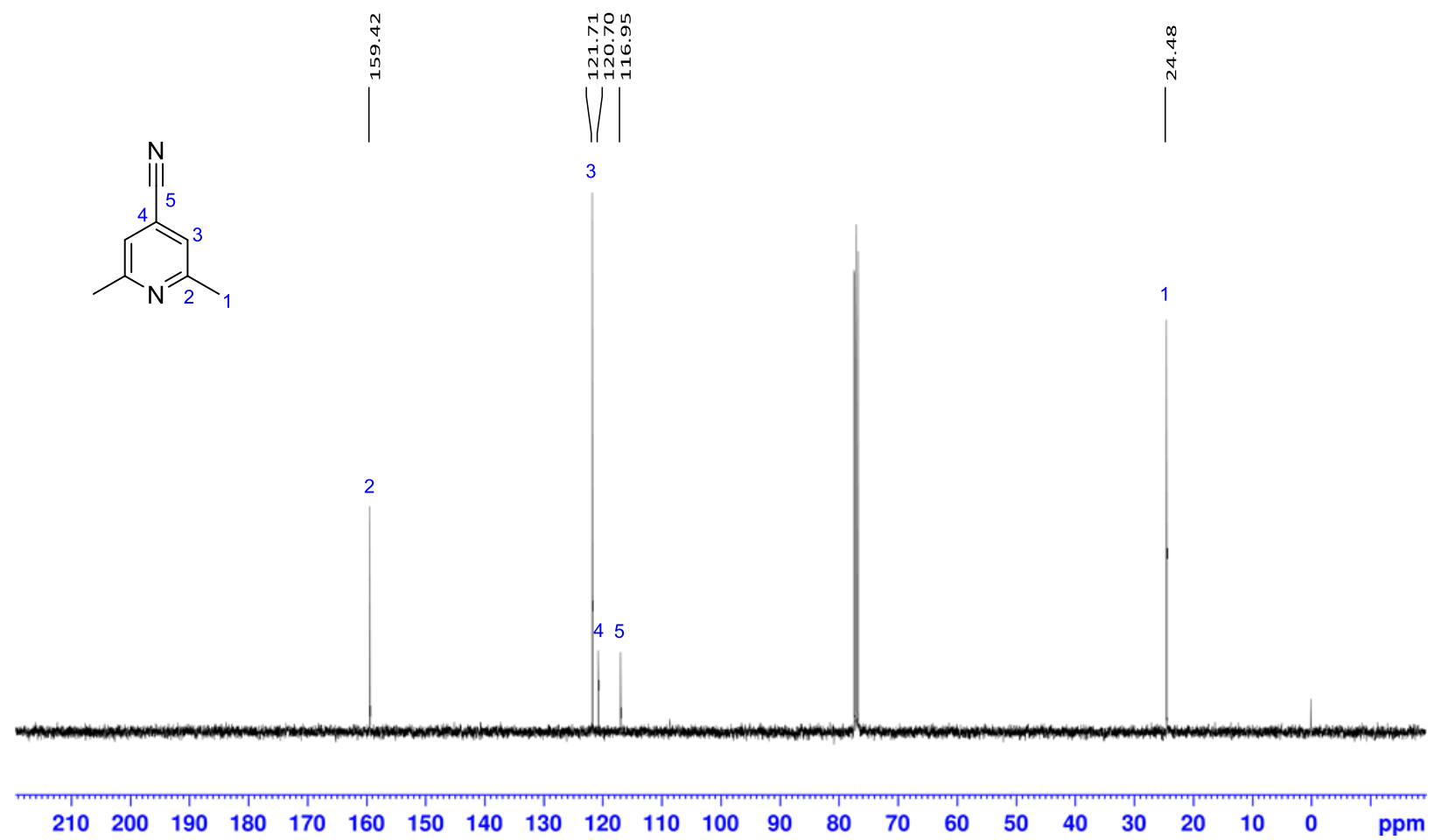

Figure S26. ${ }^{13} \mathrm{C}\left\{{ }^{1} \mathrm{H}\right\}(101 \mathrm{MHz})$ NMR spectrum of $\mathbf{1 4}$ in $\mathrm{CDCl}_{3}$ 


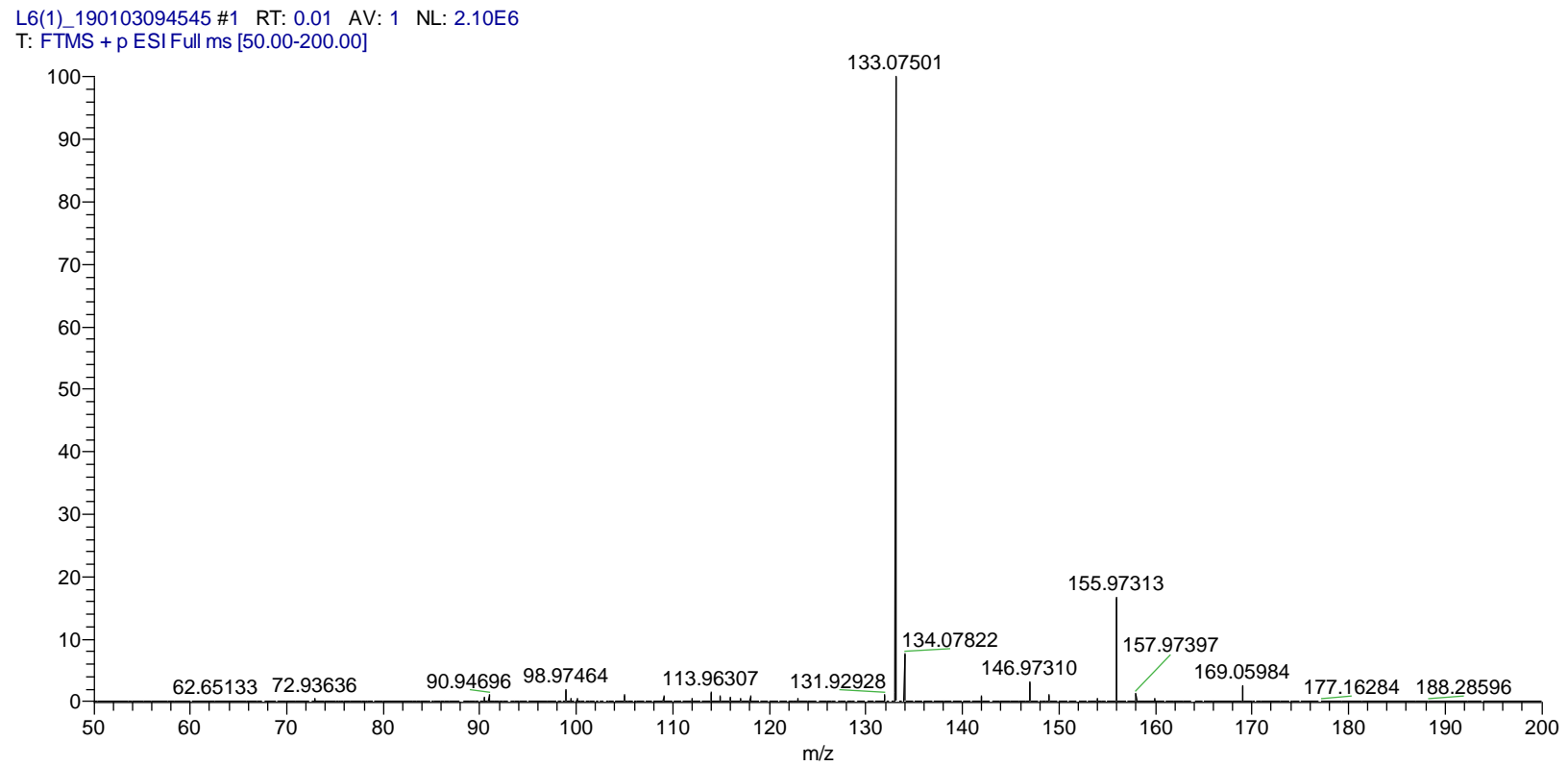

Figure S27. HR-MS spectrum of 14.

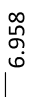

ڤึ
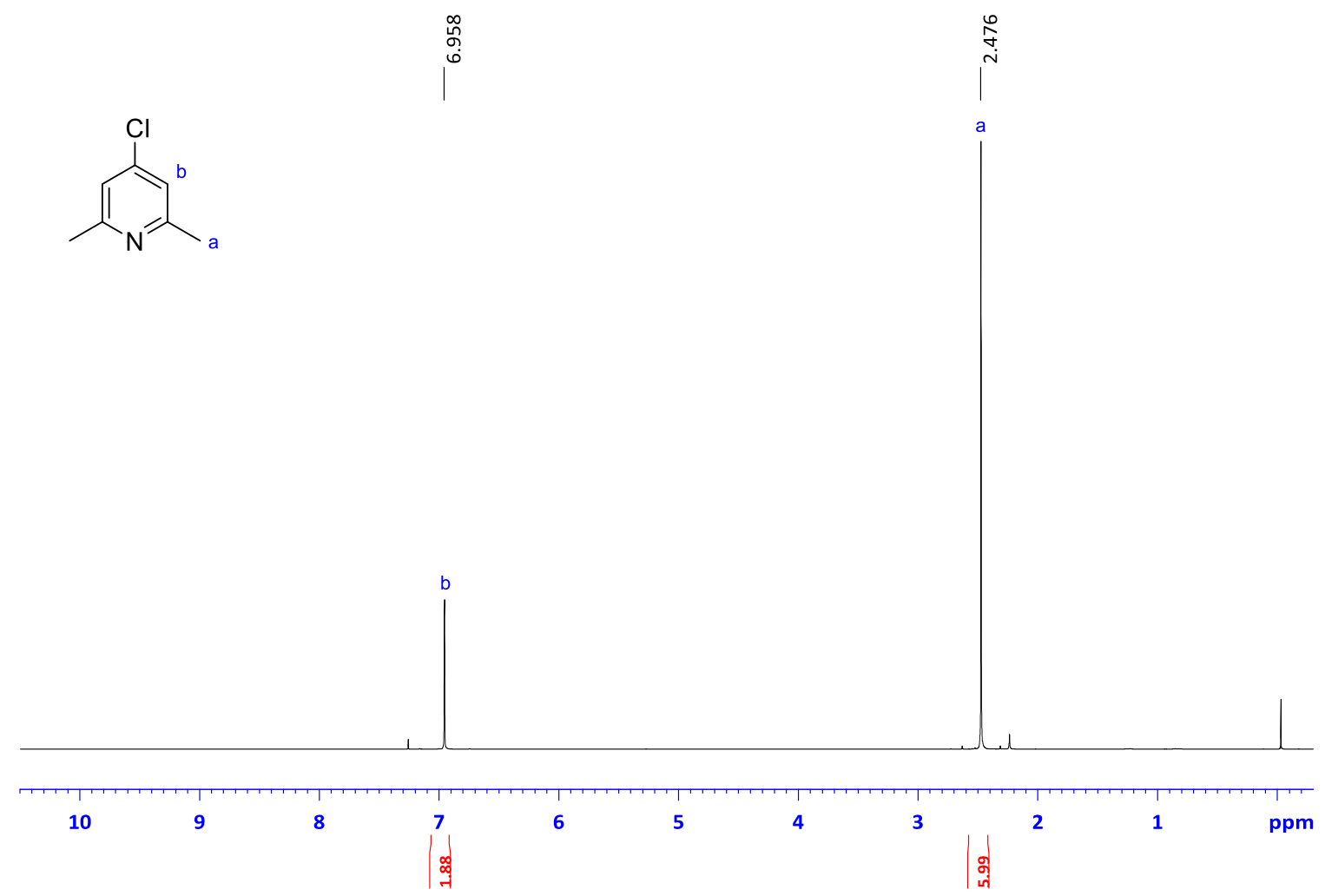

Figure S28. ${ }^{1} \mathrm{H}(400 \mathrm{MHz}) \mathrm{NMR}$ spectrum of $\mathbf{1 6}$ in $\mathrm{CDCl}_{3}$. 


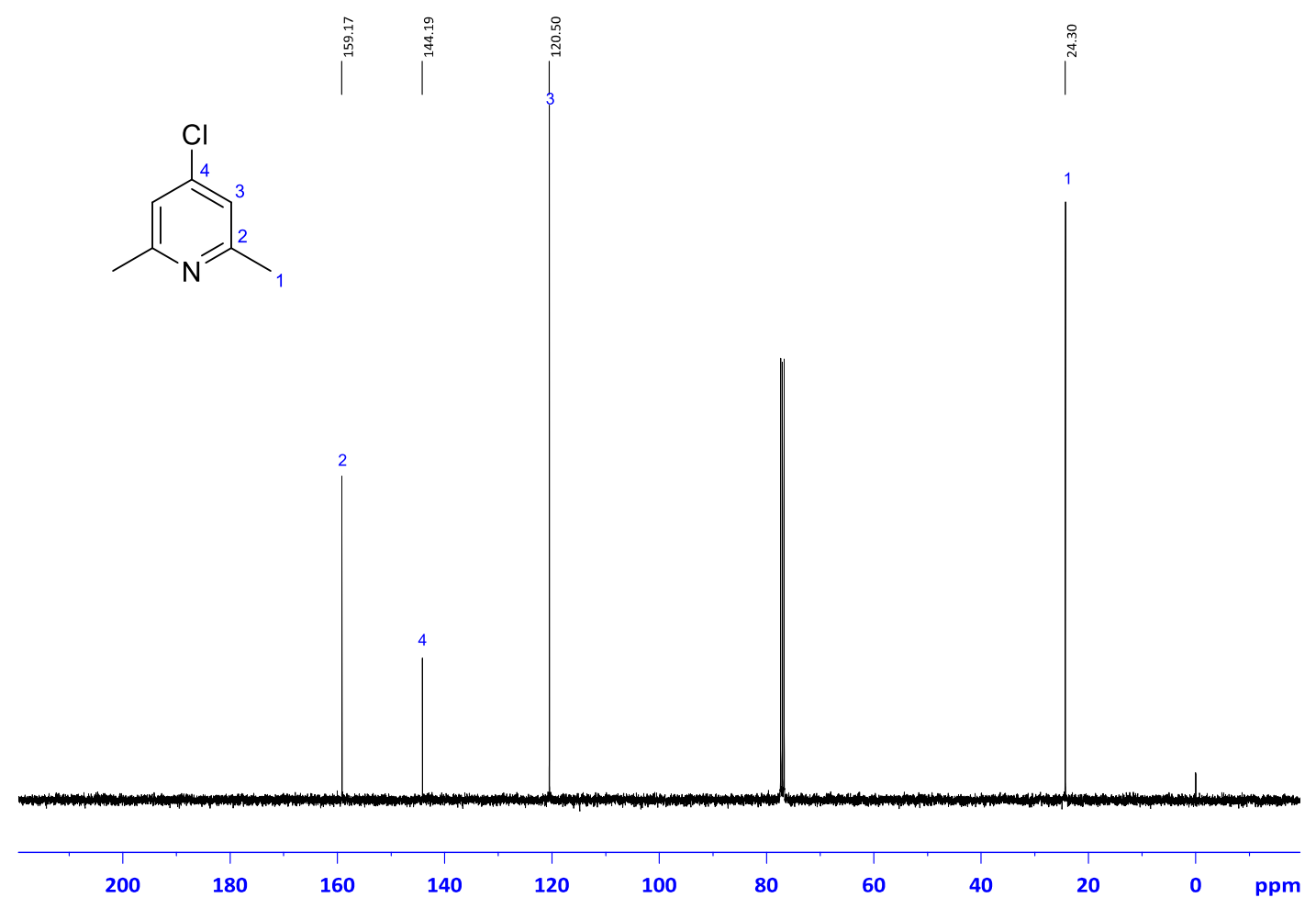

Figure S29. ${ }^{13} \mathrm{C}\left\{{ }^{1} \mathrm{H}\right\}(101 \mathrm{MHz})$ NMR spectrum of $\mathbf{1 6}$ in $\mathrm{CDCl}_{3}$.

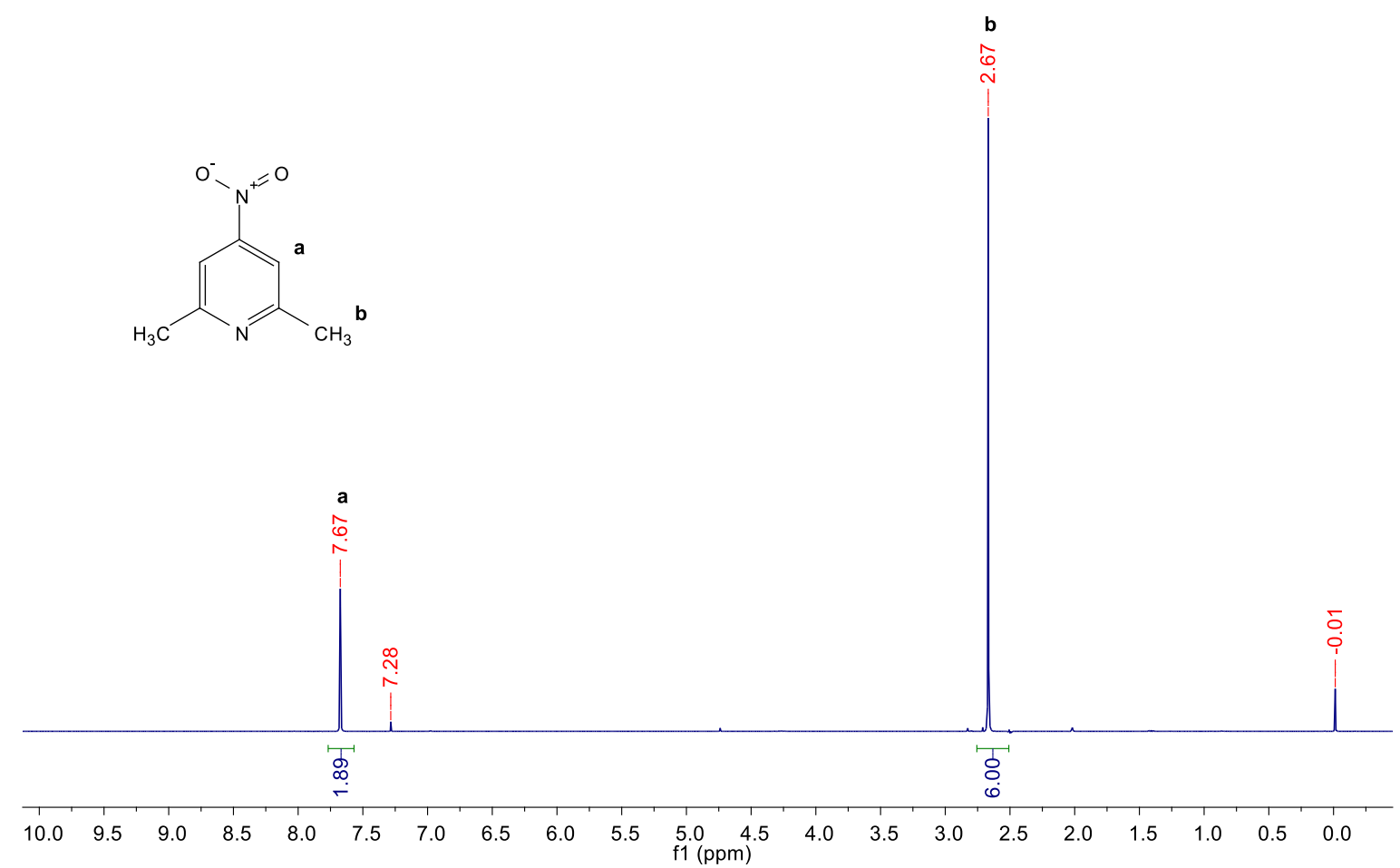

Figure S30. ${ }^{1} \mathrm{H}(400 \mathrm{MHz})$ NMR spectrum of 18 in $\mathrm{CDCl}_{3}$. 


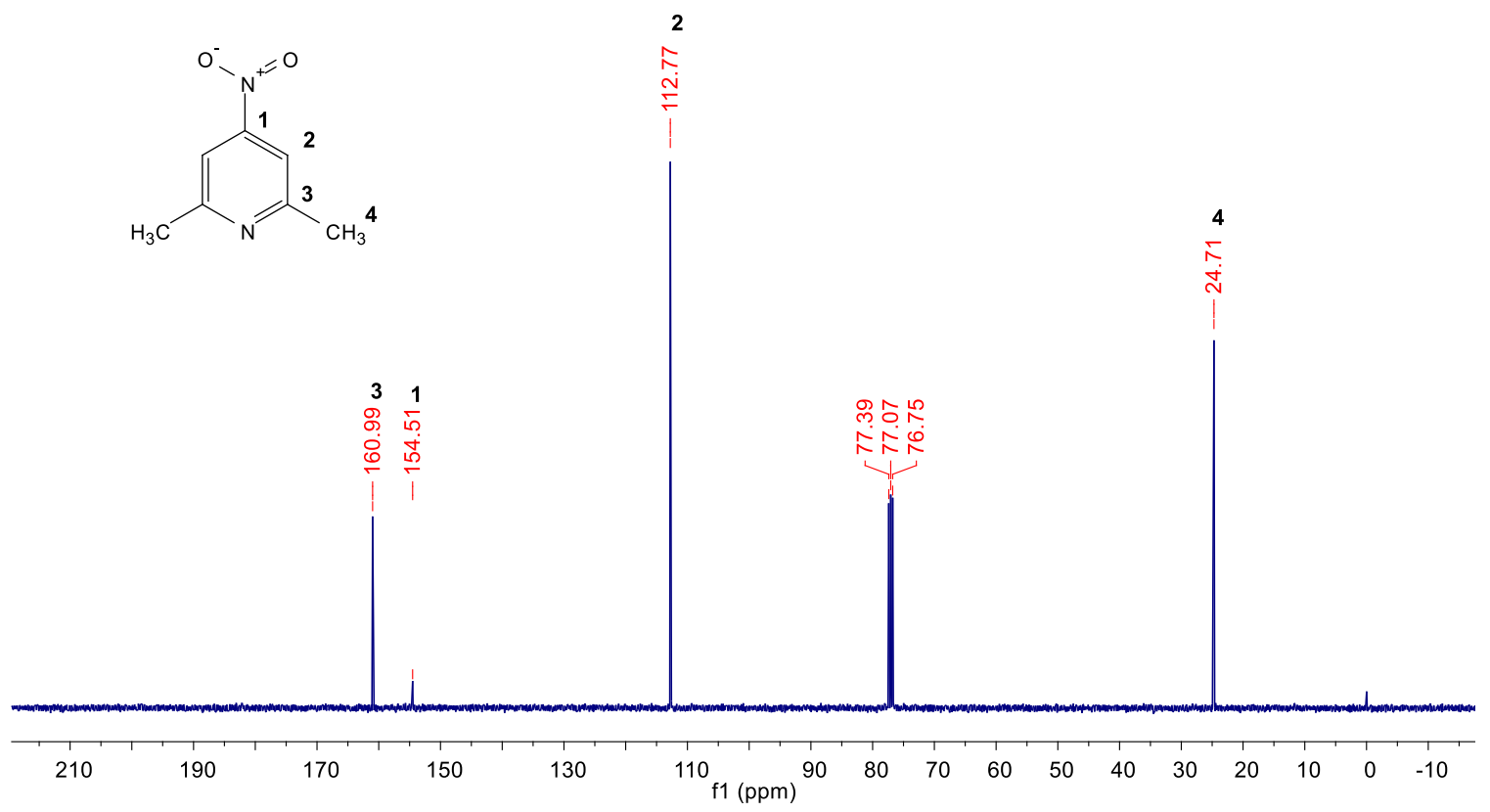

Figure S31. ${ }^{13} \mathrm{C}\left\{{ }^{1} \mathrm{H}\right\}(101 \mathrm{MHz}) \mathrm{NMR}$ spectrum of $\mathbf{1 8}$ in $\mathrm{CDCl}_{3}$.

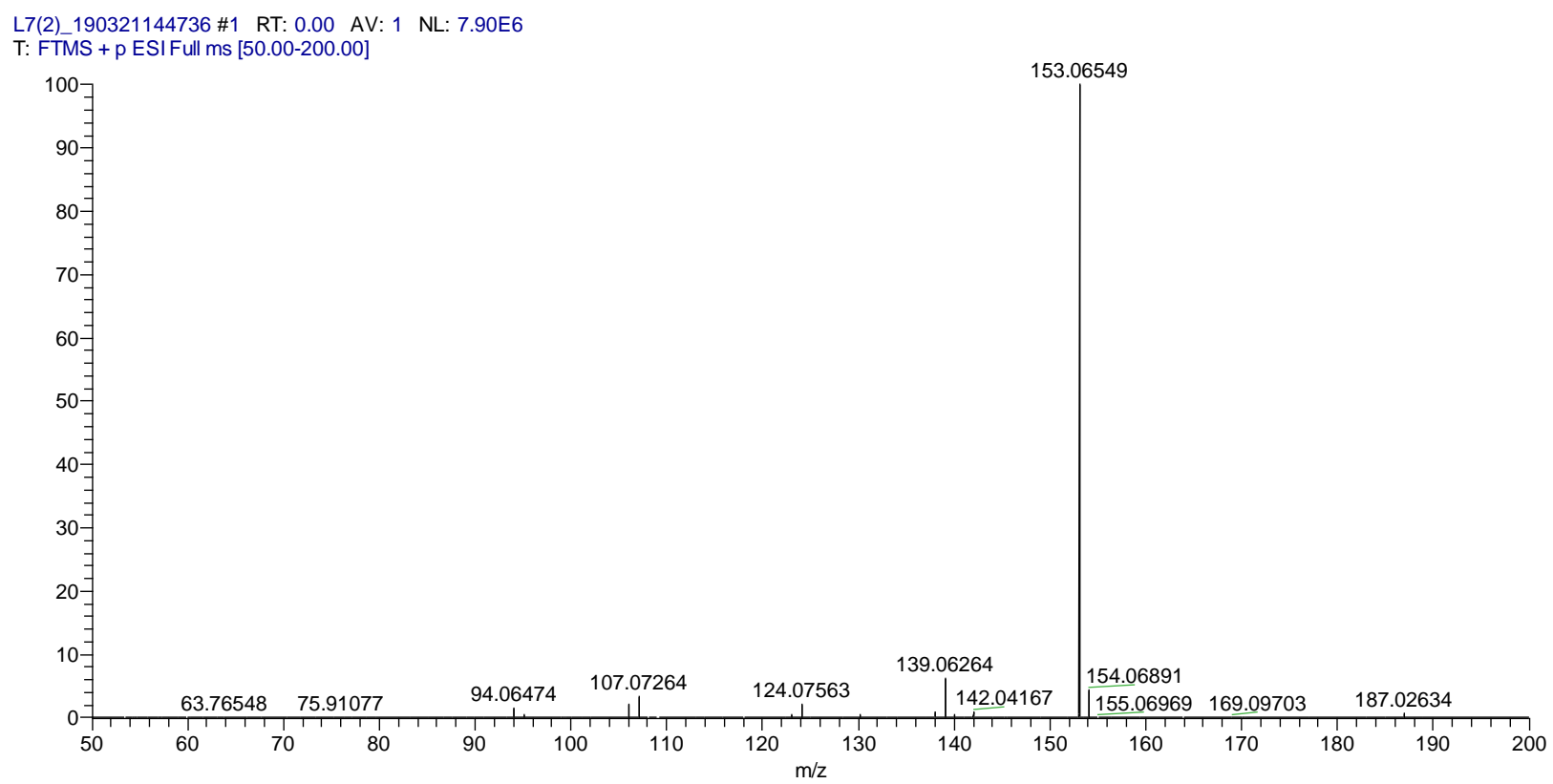

Figure S32. HR-MS spectrum of 18. 

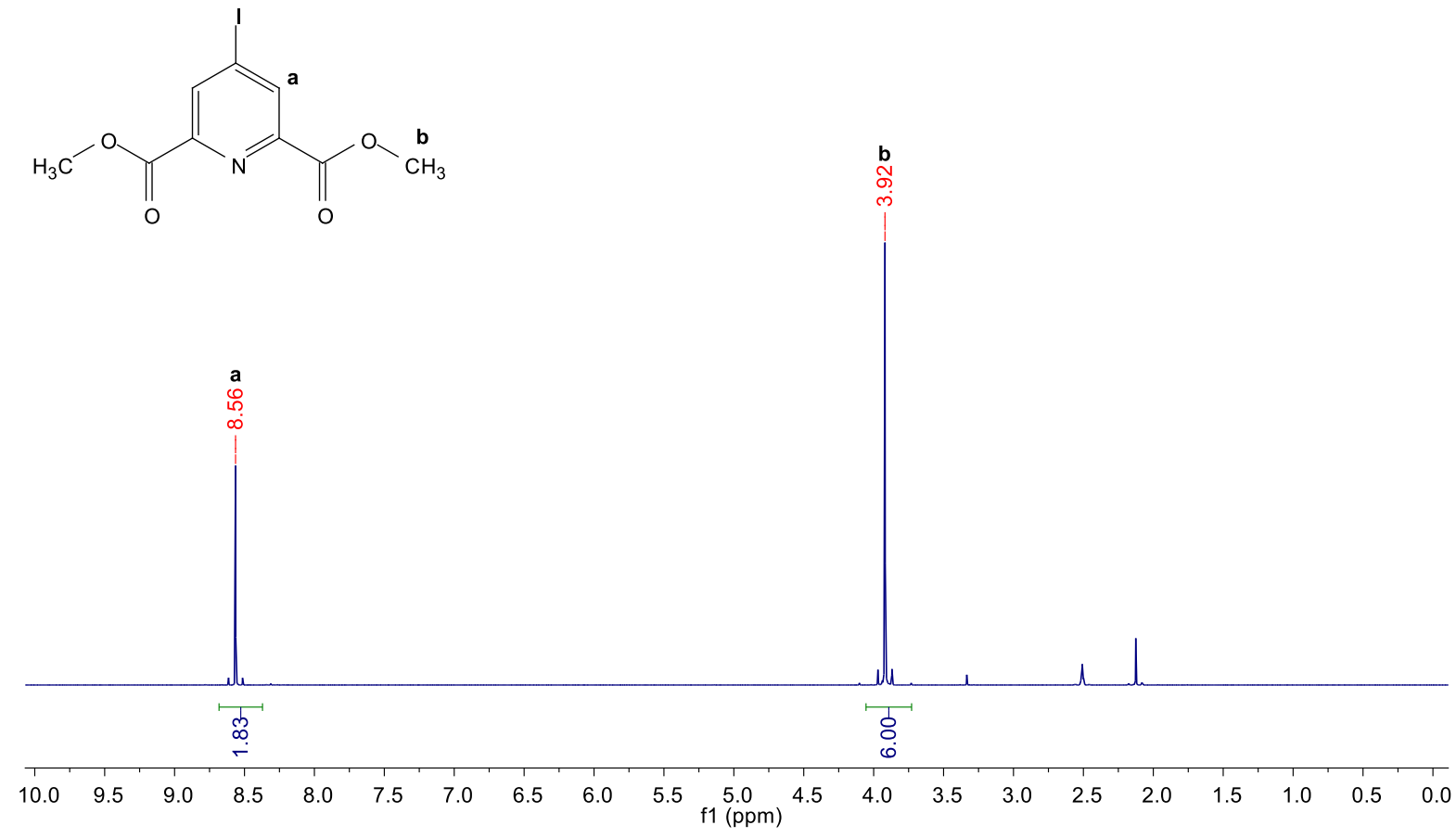

Figure S33. ${ }^{1} \mathrm{H}(400 \mathrm{MHz})$ NMR spectrum of 20 in DMSO-d $d_{6}$

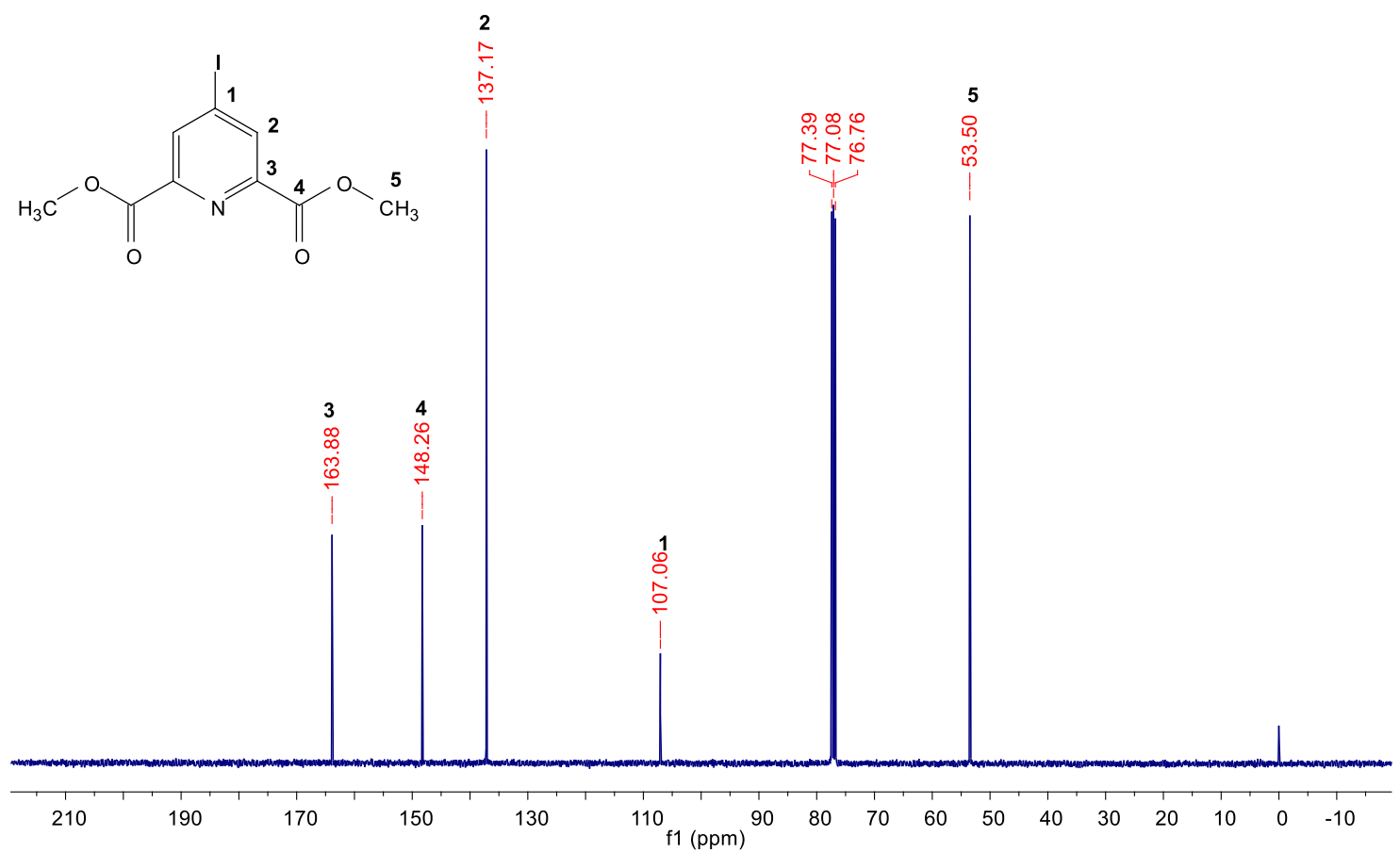

Figure S34. ${ }^{13} \mathrm{C}\left\{{ }^{1} \mathrm{H}\right\}(101 \mathrm{MHz})$ NMR spectrum of 20 in $\mathrm{CDCl}_{3}$. 


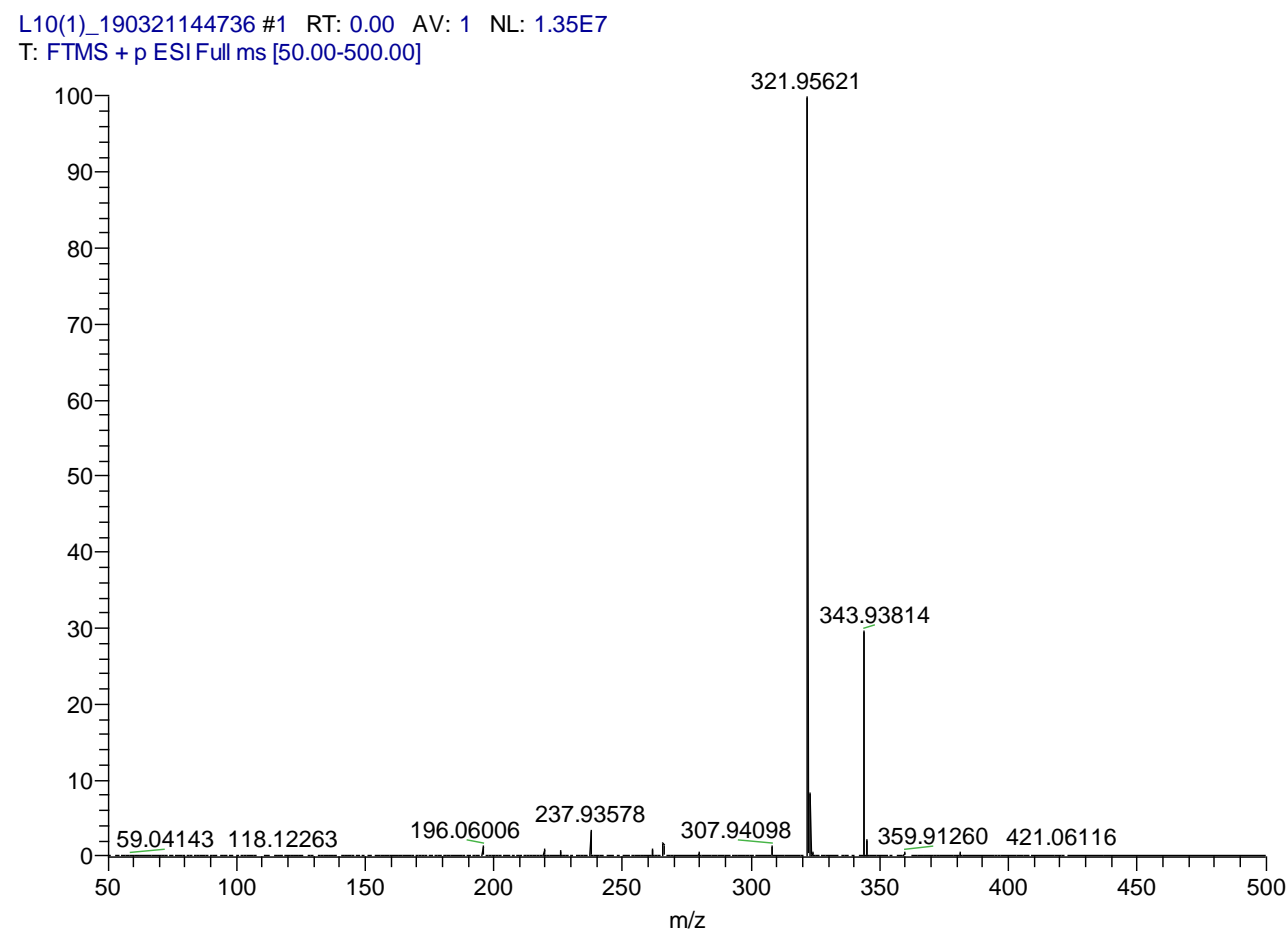

Figure S35. HR-MS spectrum of 20.
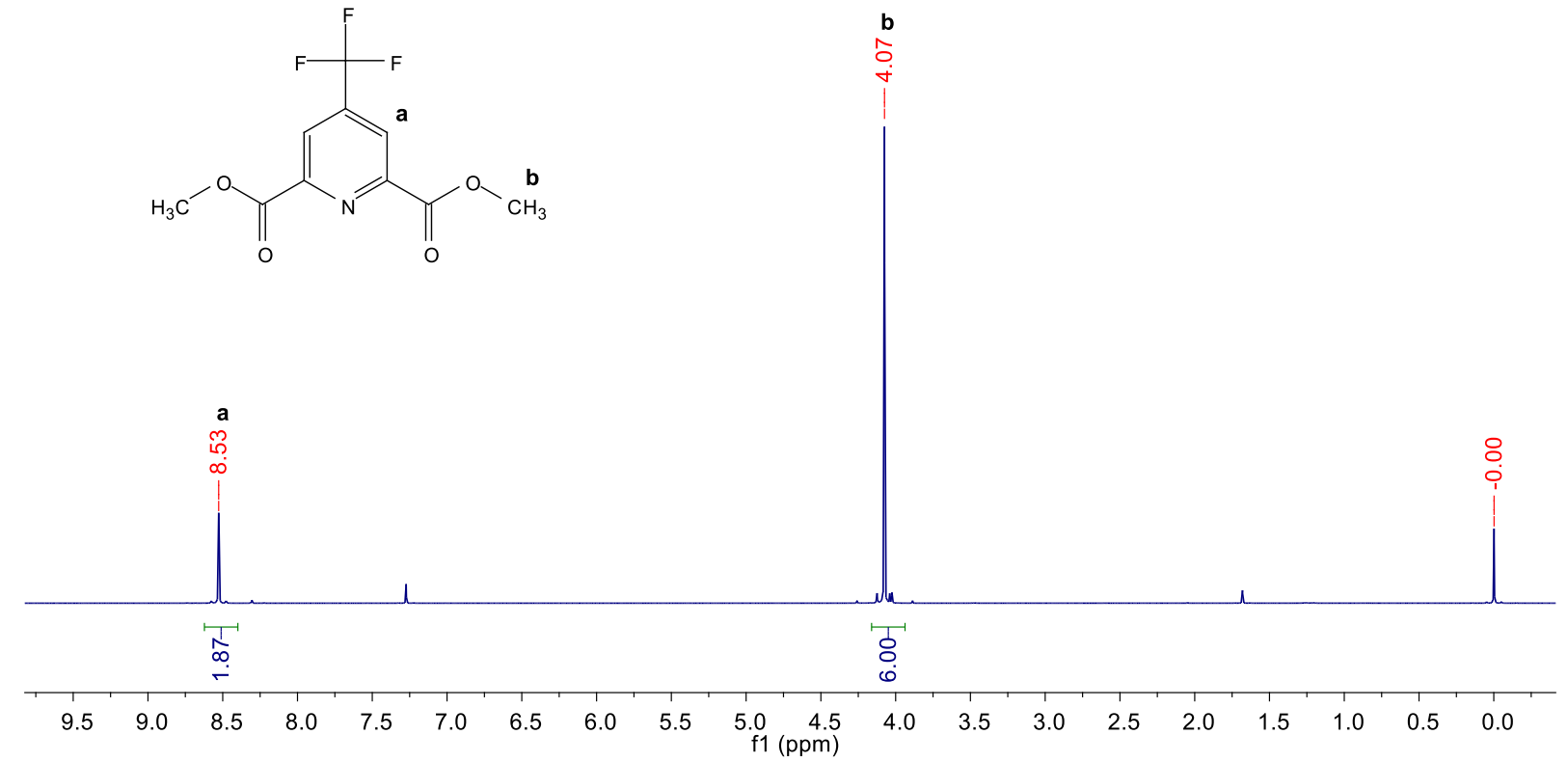

Figure S36. ${ }^{1} \mathrm{H}(400 \mathrm{MHz}) \mathrm{NMR}$ spectrum of 21 in $\mathrm{CDCl}_{3}$. 


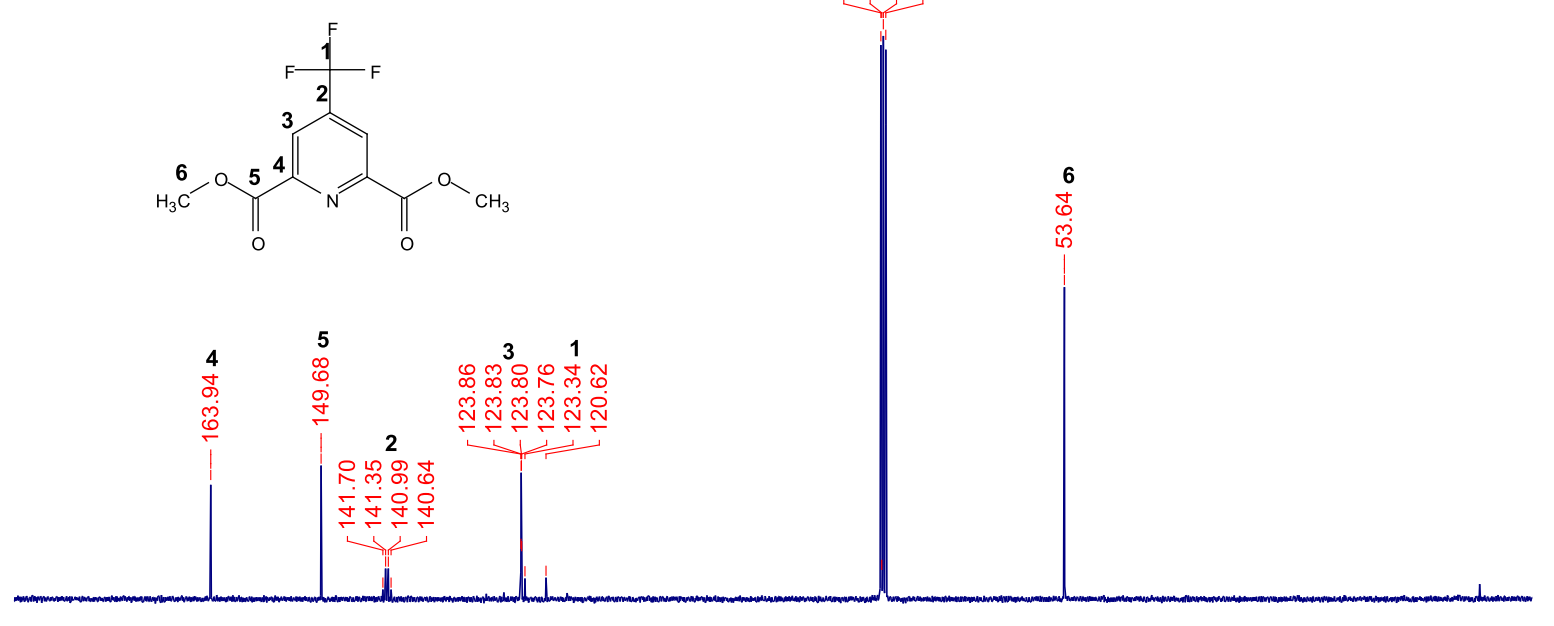

m

र下宓最

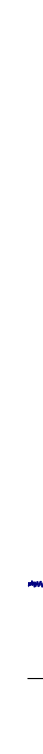

Figure S37. ${ }^{13} \mathrm{C}\left\{{ }^{1} \mathrm{H}\right\}(101 \mathrm{MHz}) \mathrm{NMR}$ spectrum of 21 in $\mathrm{CDCl}_{3}$.

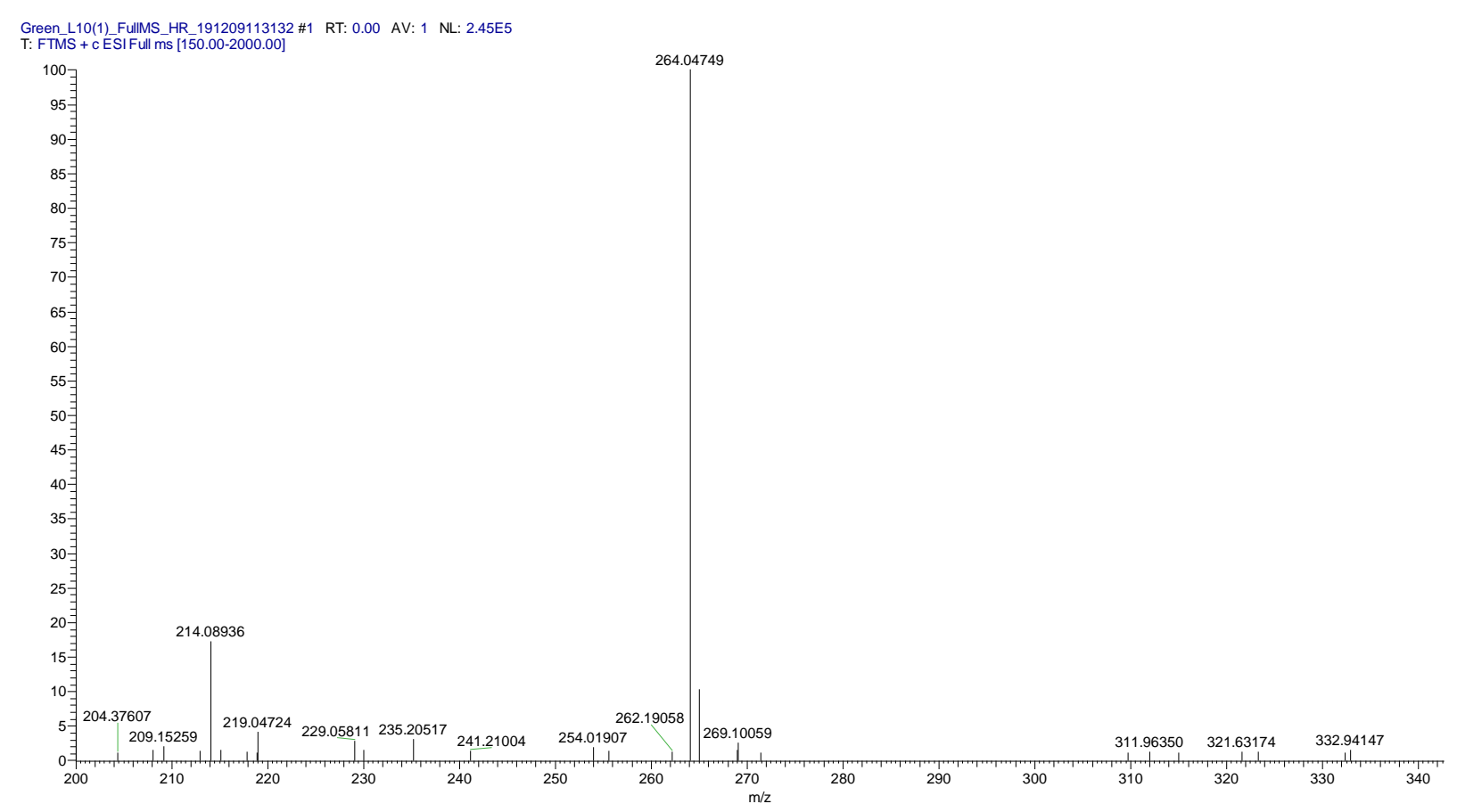

Figure S38. HR-MS of compound 21. 


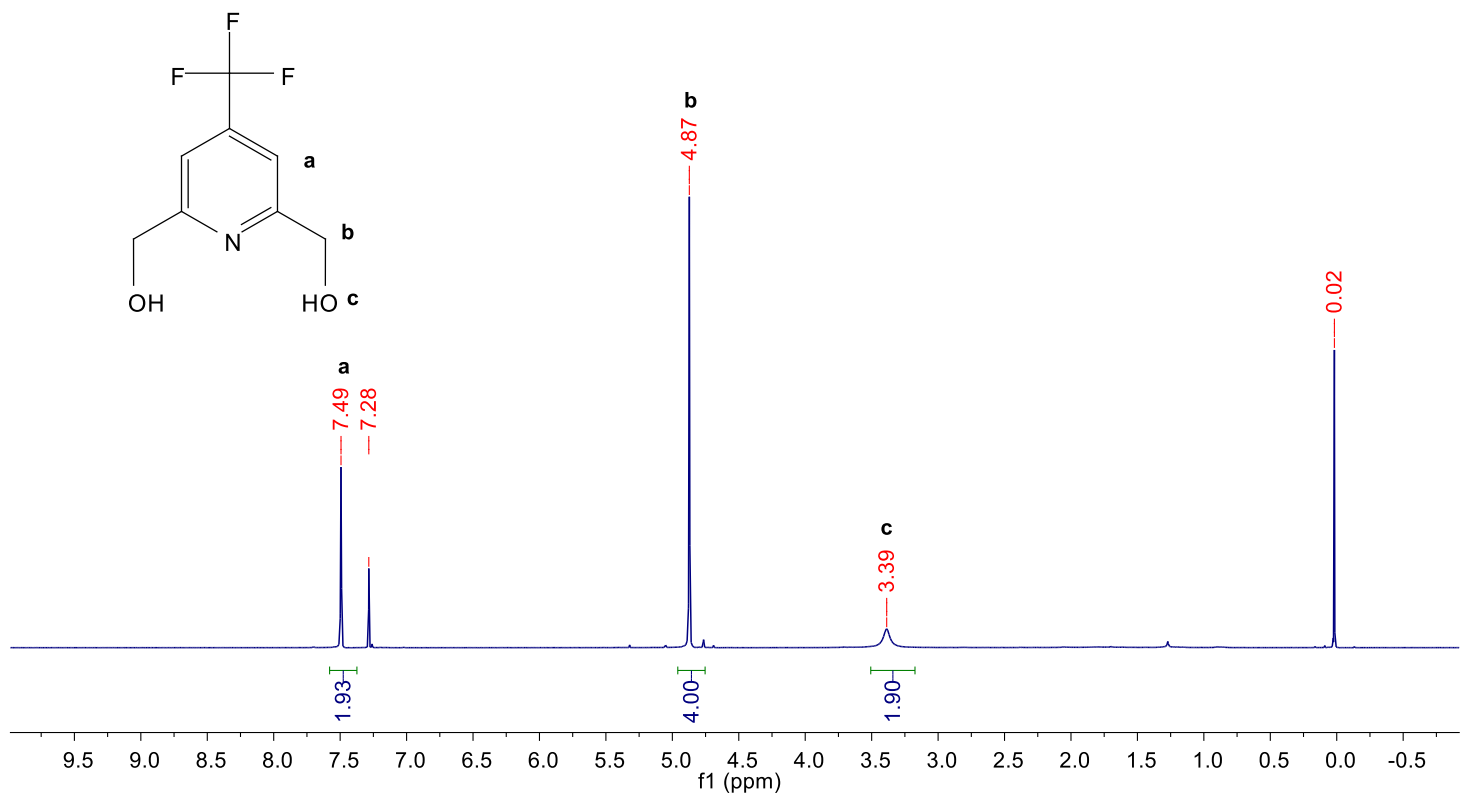

Figure S39. ${ }^{1} \mathrm{H}(400 \mathrm{MHz})$ NMR spectrum of 22 in $\mathrm{CDCl}_{3}$.

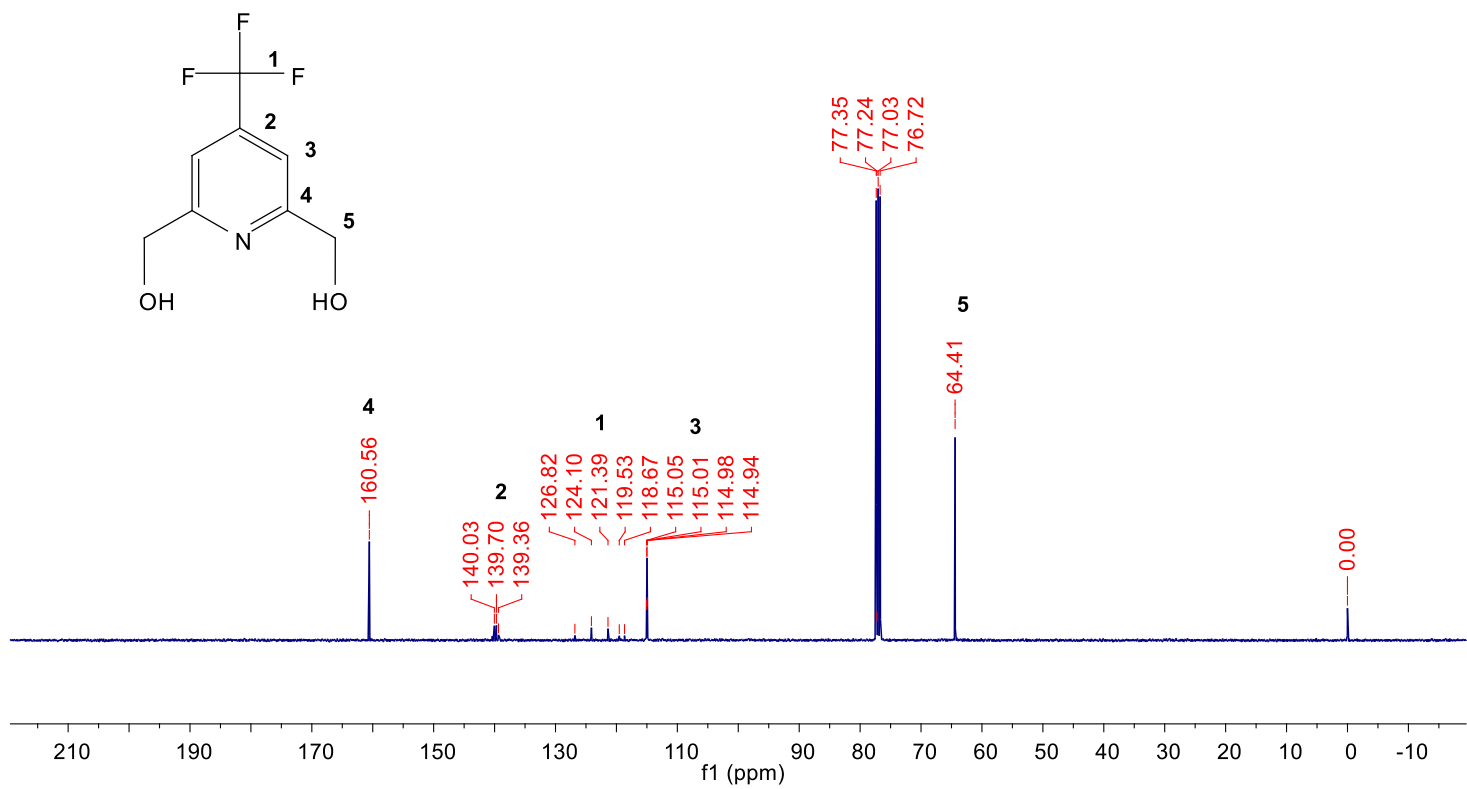

Figure S40. ${ }^{13} \mathrm{C}\left\{{ }^{1} \mathrm{H}\right\}(101 \mathrm{MHz})$ NMR spectrum of 22 in $\mathrm{CDCl}_{3}$. 


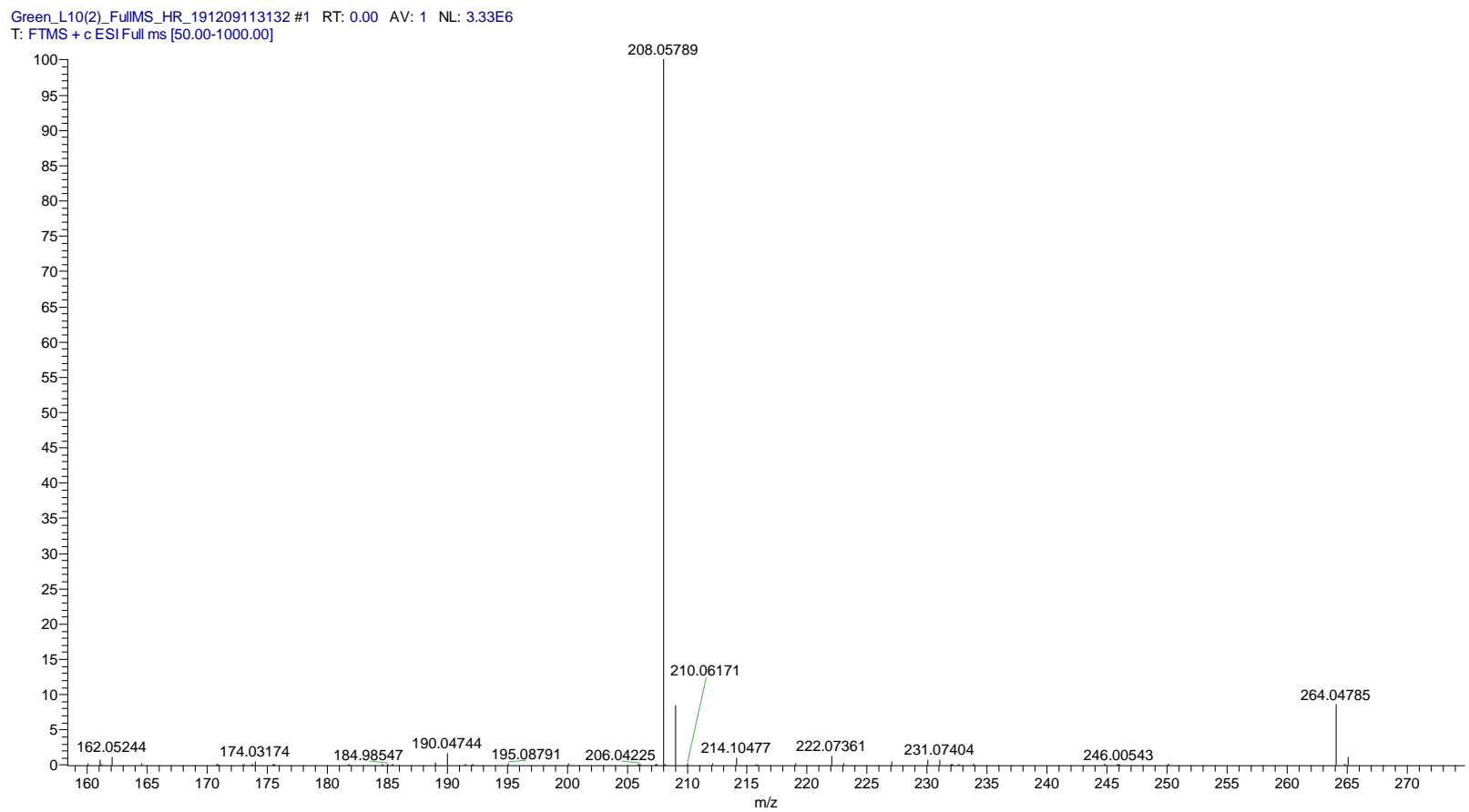

Figure S41. HR-MS of compound 22.

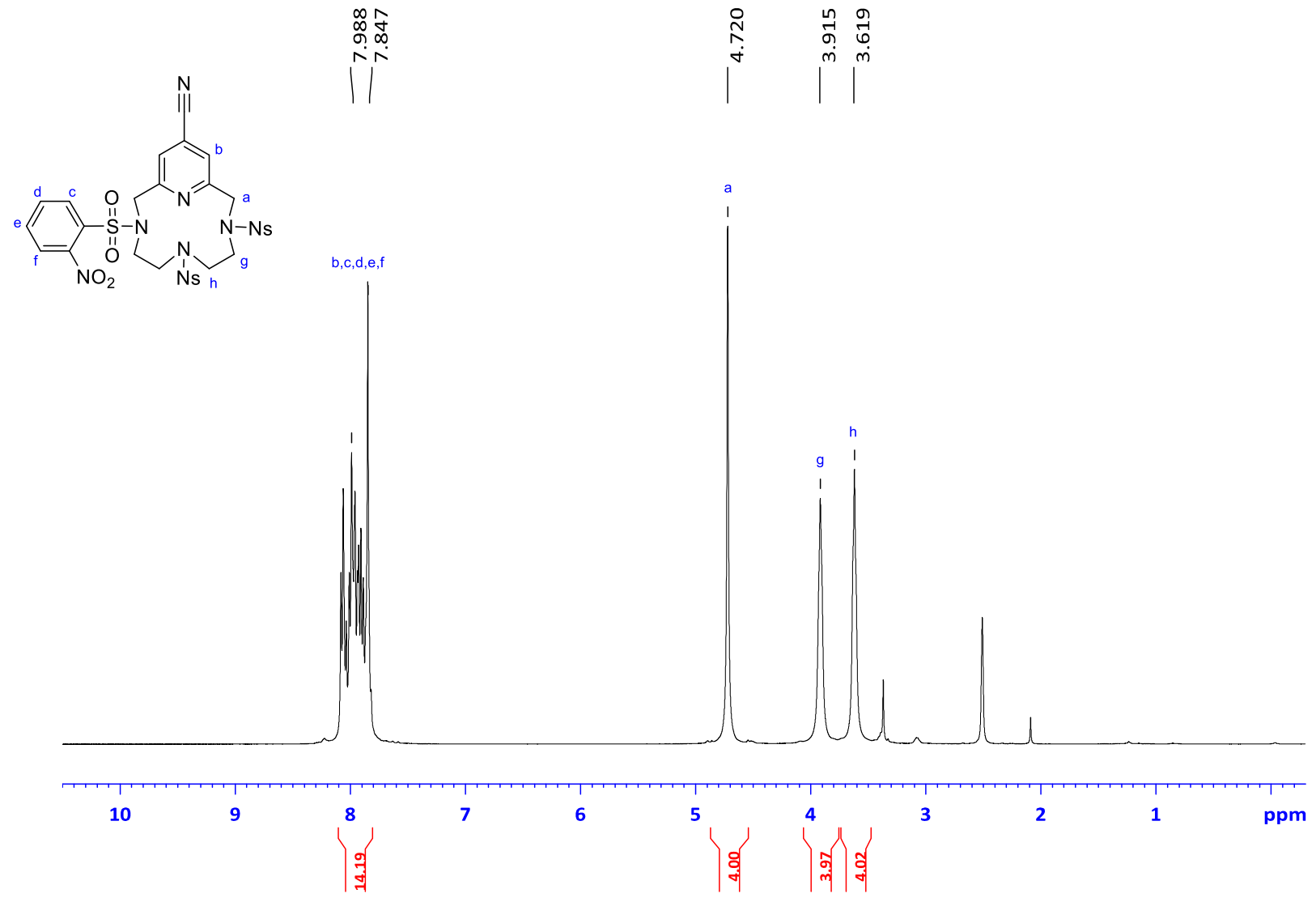

Figure $\mathbf{S 4 2} .{ }^{1} \mathrm{H}(400 \mathrm{MHz})$ NMR spectrum of 23 in DMSO-d 6 . 

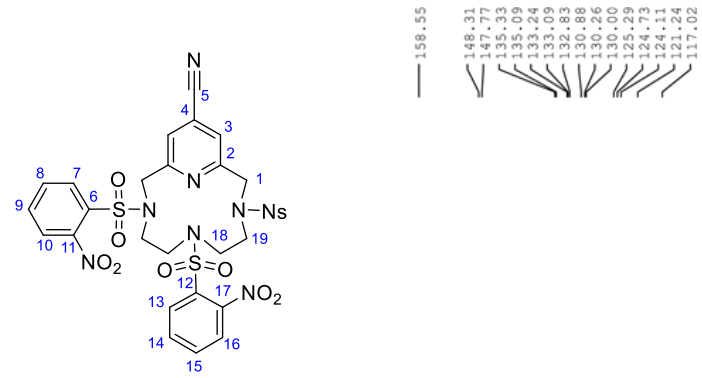

\section{$\mid$}

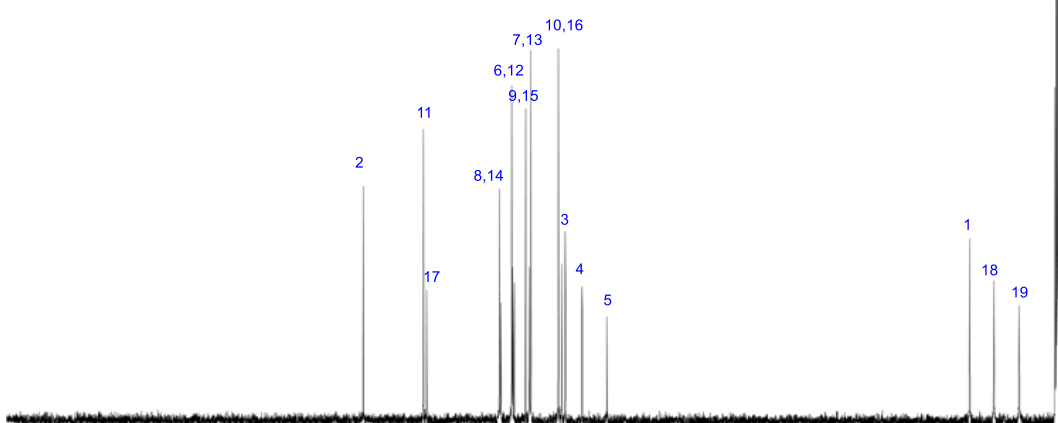

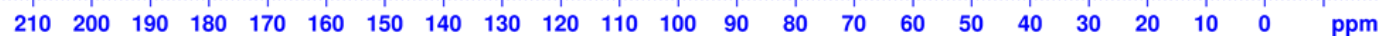

Figure S43. ${ }^{13} \mathrm{C}\left\{{ }^{1} \mathrm{H}\right\}(101 \mathrm{MHz})$ NMR spectrum of 23 in DMSO- $d_{6}$.

16(3)_190321144736 \#2 RT: 0.00 AV: 1 NL: 6.25E5

T: ITMS + p ESI Full ms [500.00-1000.00]

100

90

$80=528.50000$

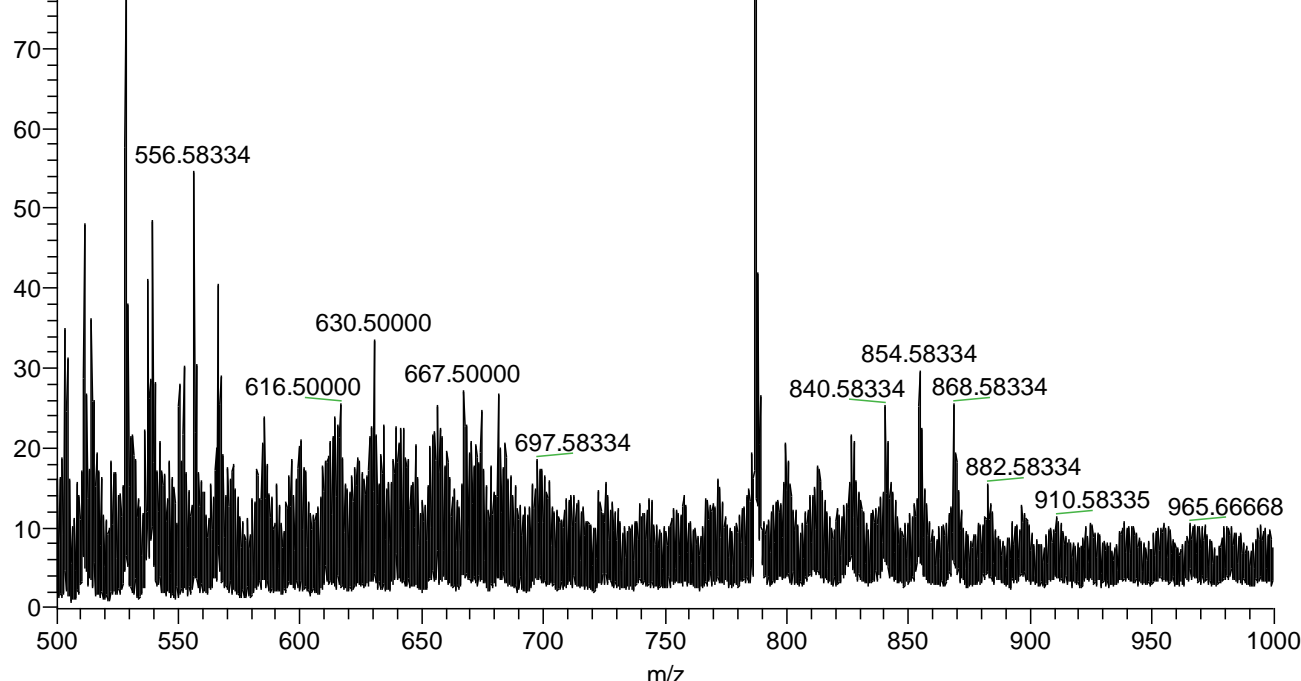

Figure S44. HR-MS of 23. 


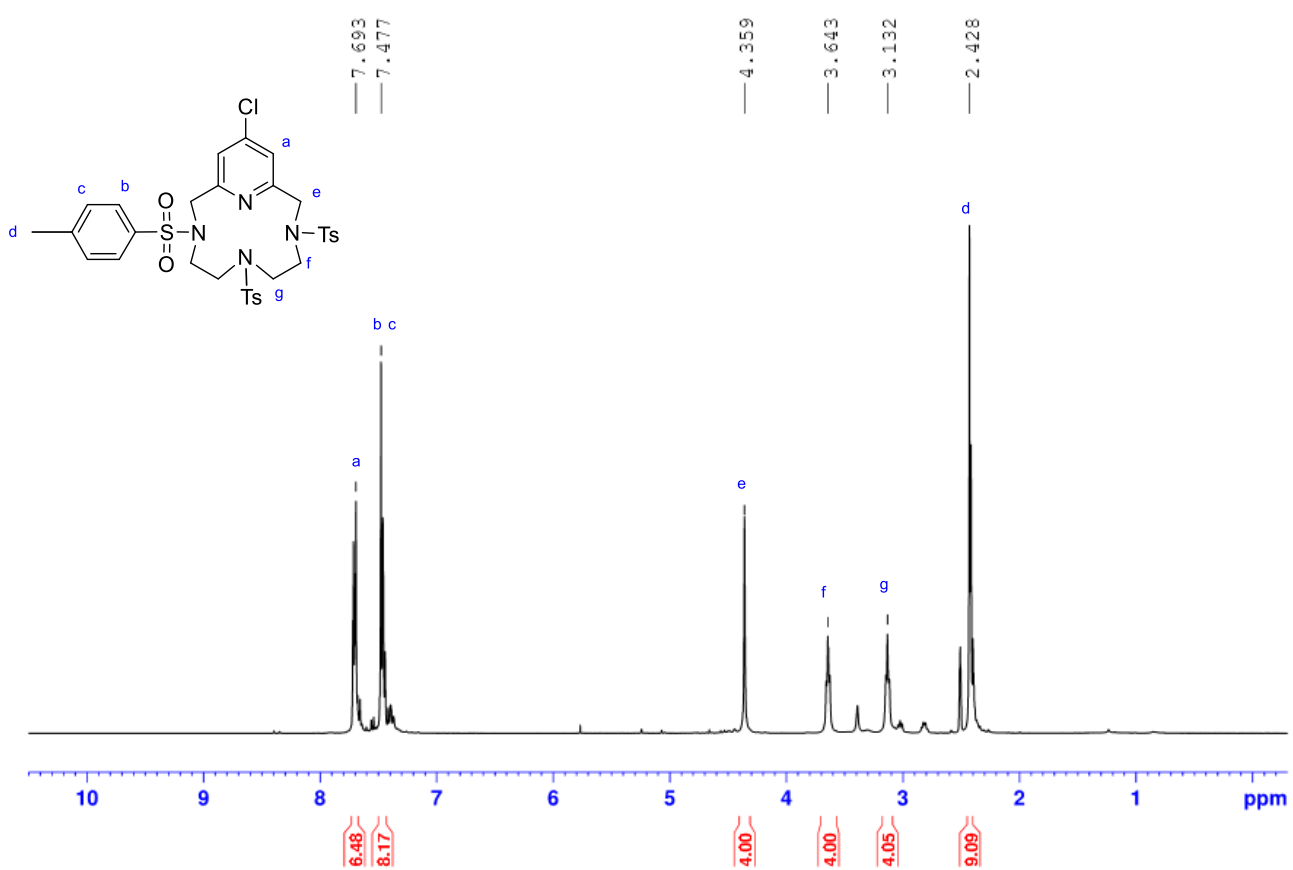

Figure S45. ${ }^{1} \mathrm{H}(400 \mathrm{MHz})$ NMR spectrum of 24 in DMSO-d 6 .

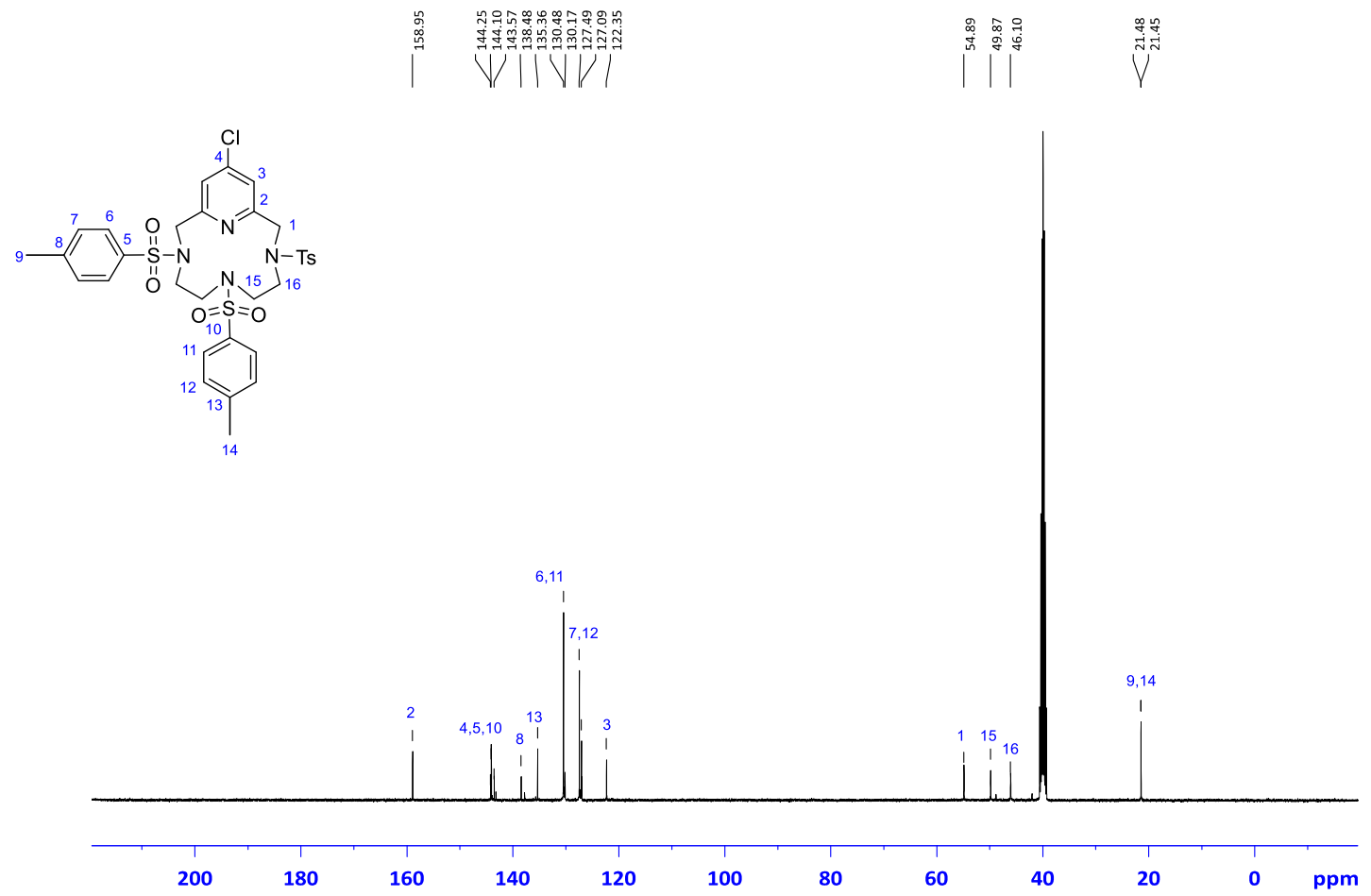

Figure S46. ${ }^{13} \mathrm{C}\left\{{ }^{1} \mathrm{H}\right\}(101 \mathrm{MHz}) \mathrm{NMR}$ spectrum of 24 in DMSO- $d_{6}$. 


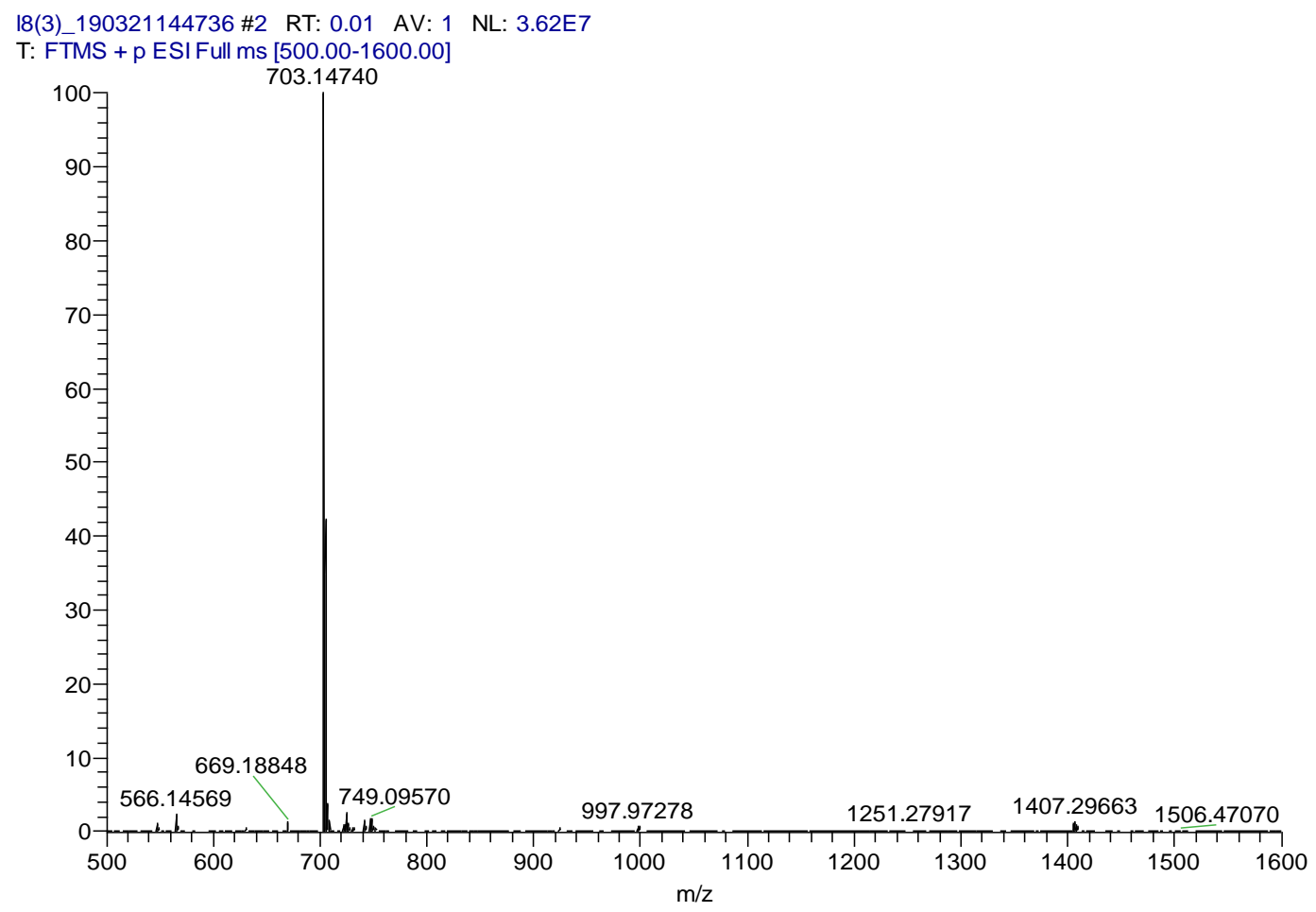

Figure S47. HR-MS spectrum of 24.

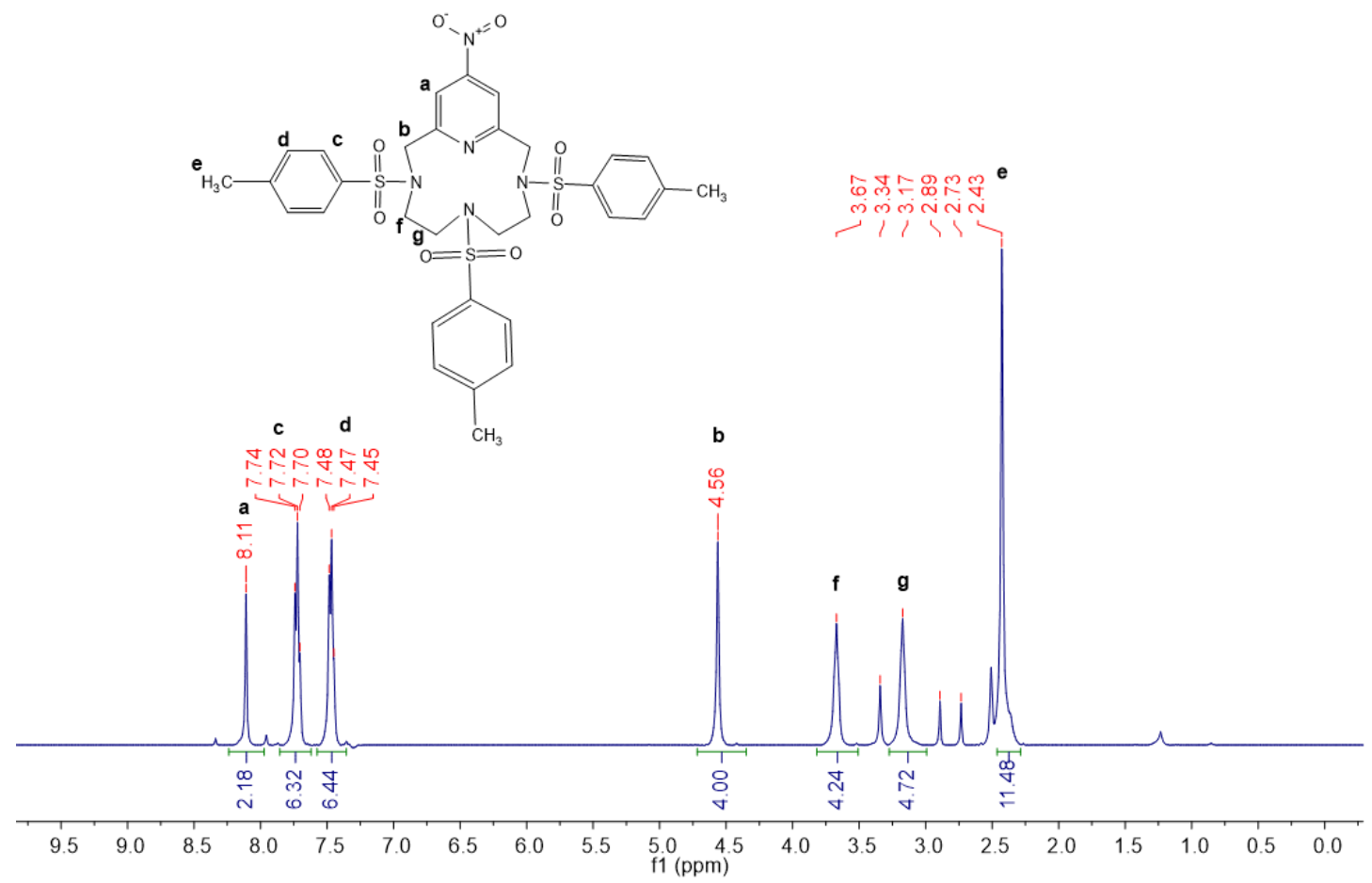

Figure S48. ${ }^{1} \mathrm{H}(400 \mathrm{MHz})$ NMR spectrum of 25 in DMSO- $d_{6}$. 


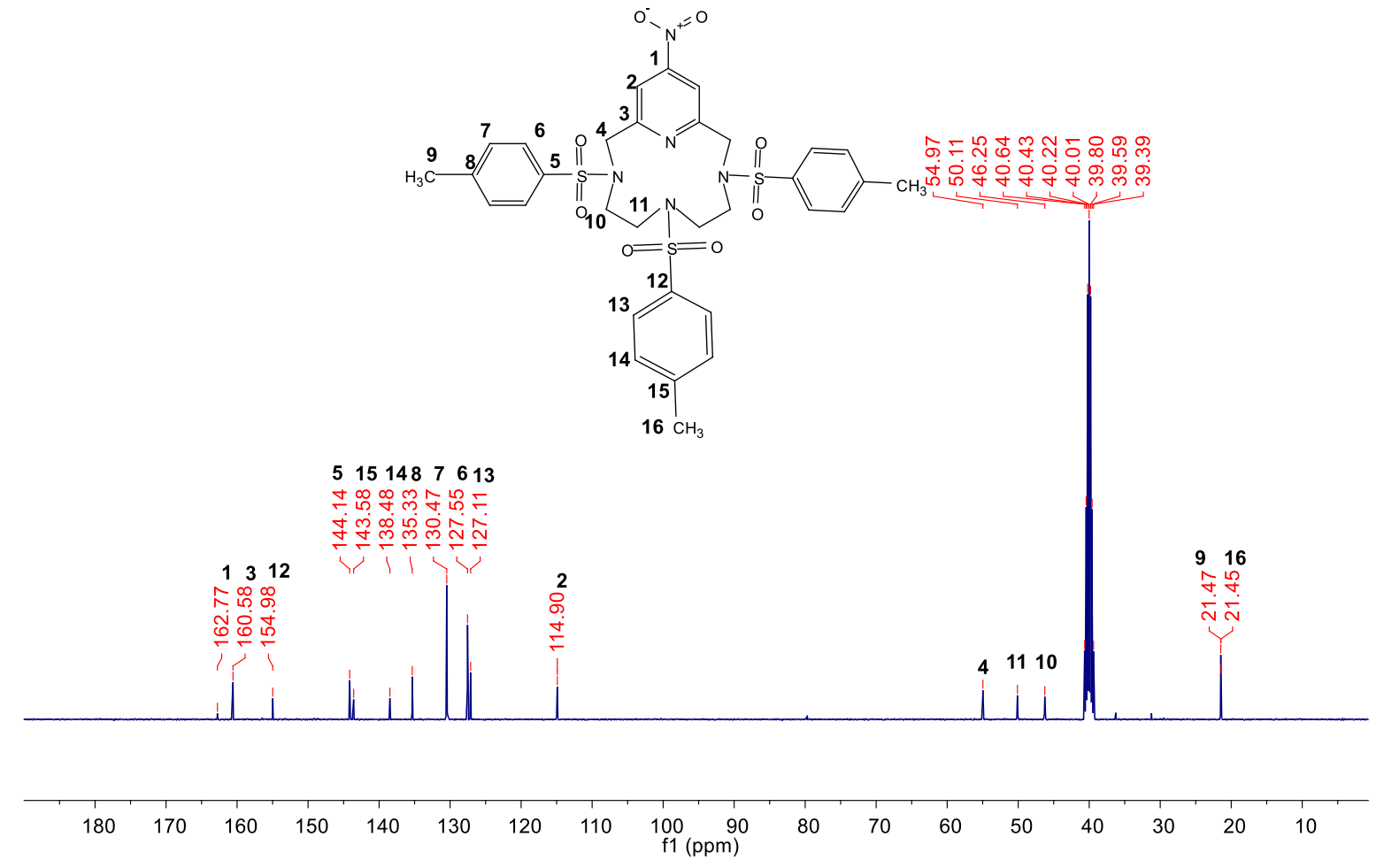

Figure S49. ${ }^{13} \mathrm{C}\left\{{ }^{1} \mathrm{H}\right\}(101 \mathrm{MHz}) \mathrm{NMR}$ spectrum of 25 in DMSO- $d_{6}$.

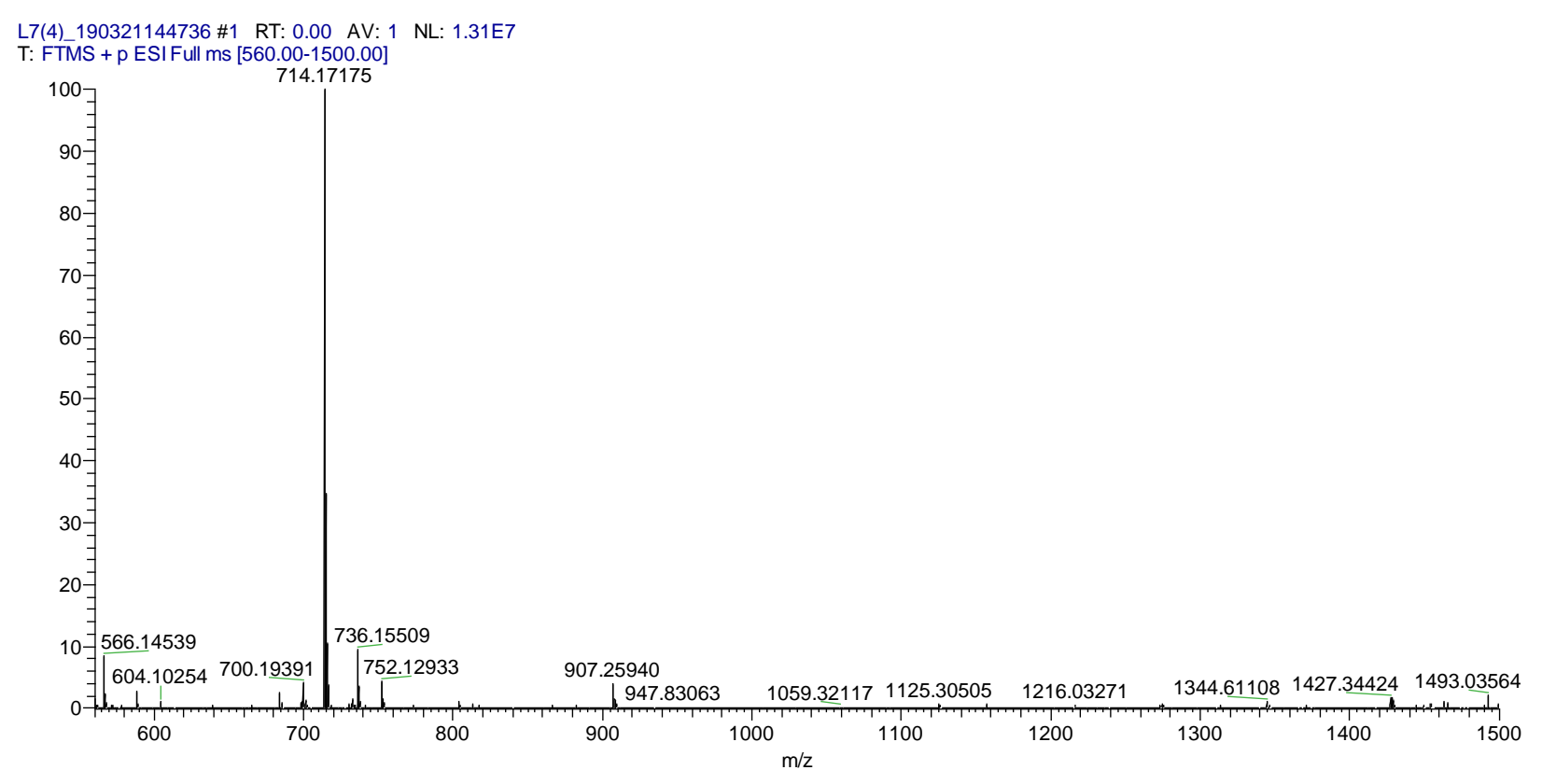

Figure S50. HR-MS of compound 25. 


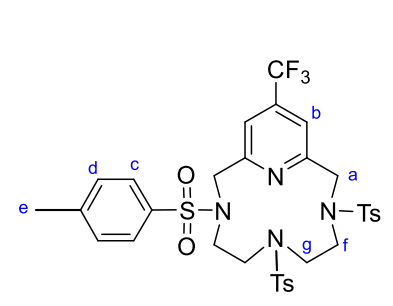

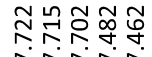

ini
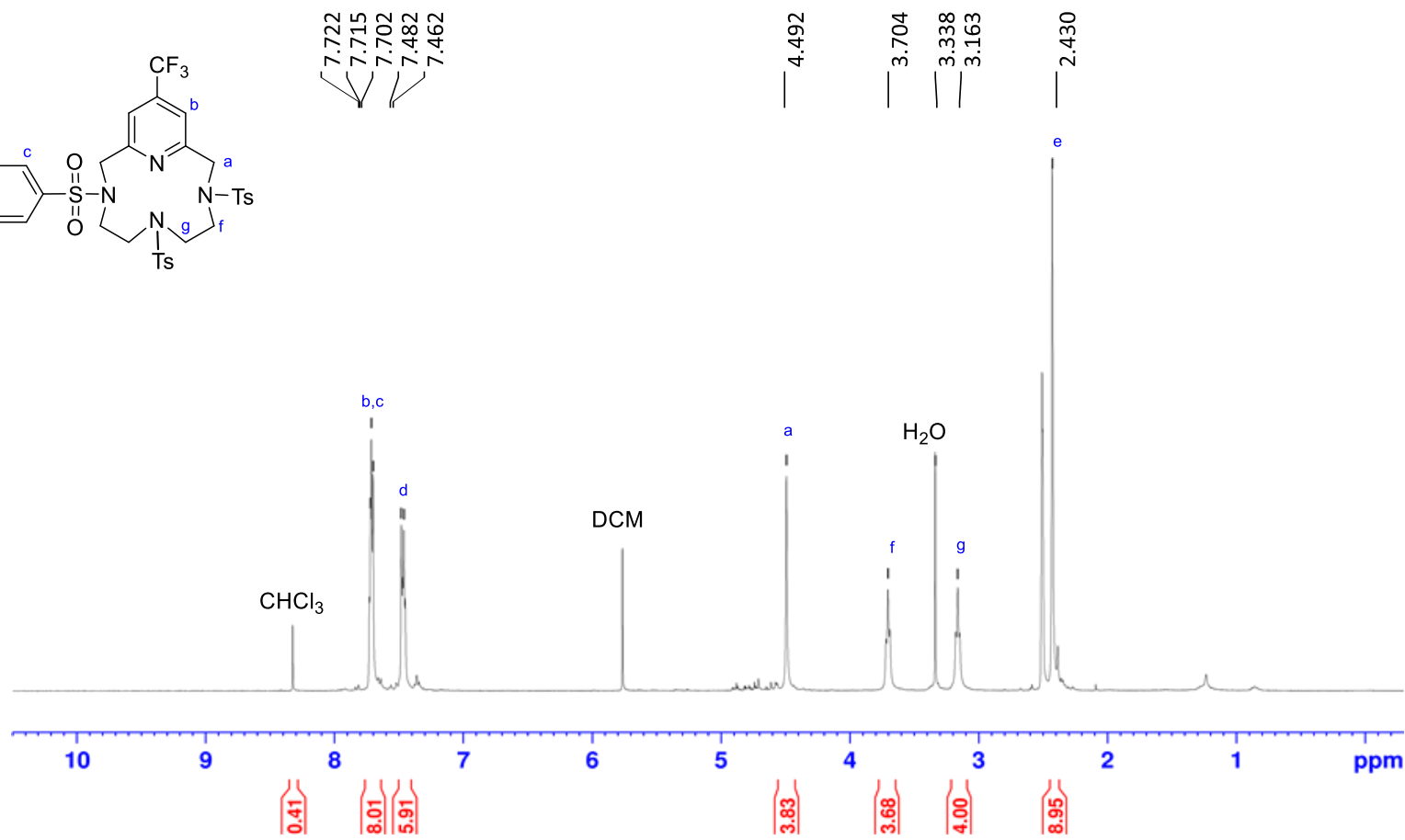

Figure S51. ${ }^{1} \mathrm{H}(400 \mathrm{MHz})$ NMR spectrum of 26 in DMSO- $d_{6}$.
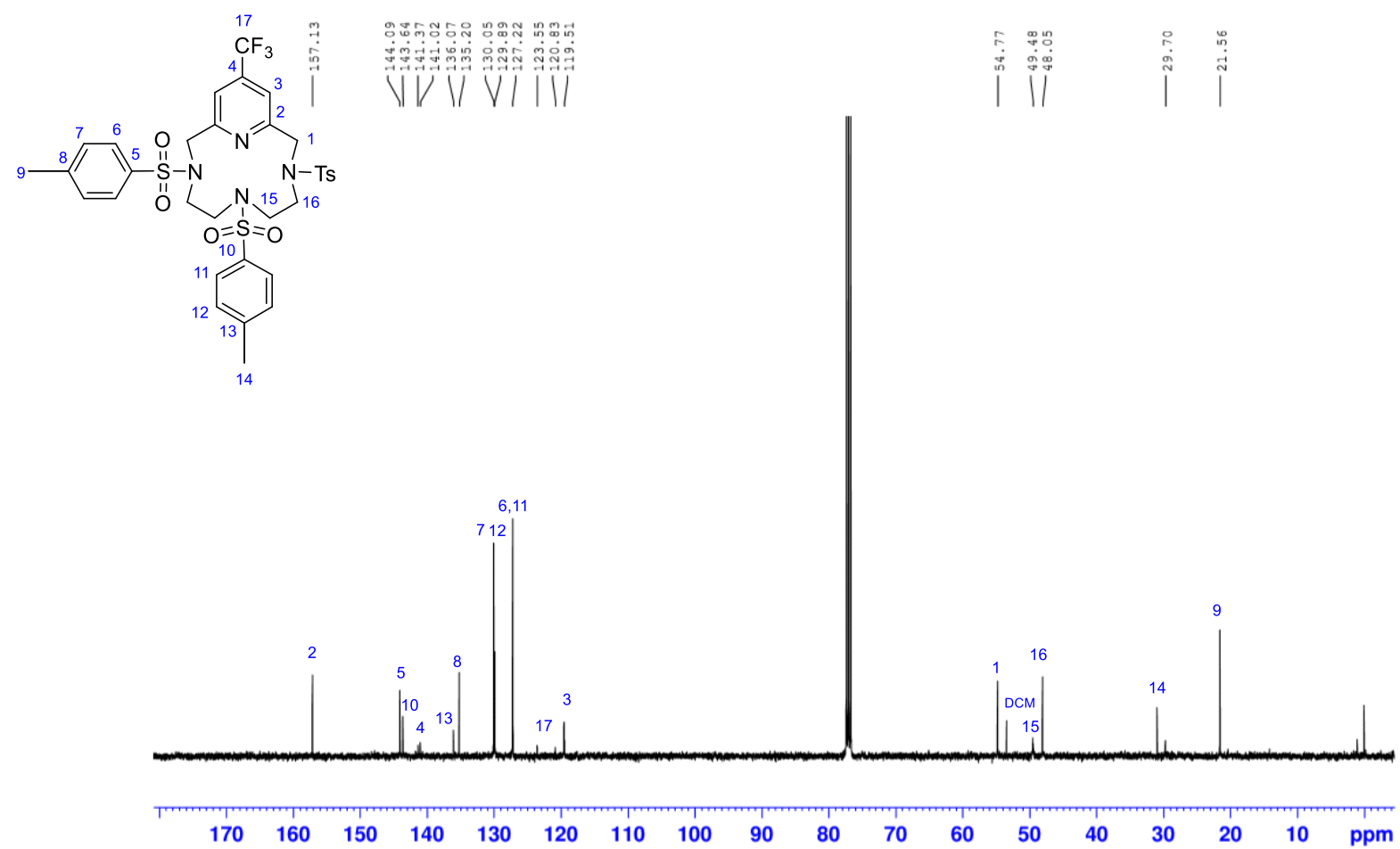

Figure S52. ${ }^{13} \mathrm{C}\left\{{ }^{1} \mathrm{H}\right\}(101 \mathrm{MHz}) \mathrm{NMR}$ spectrum of 26 in $\mathrm{CDCl}_{3}$. 


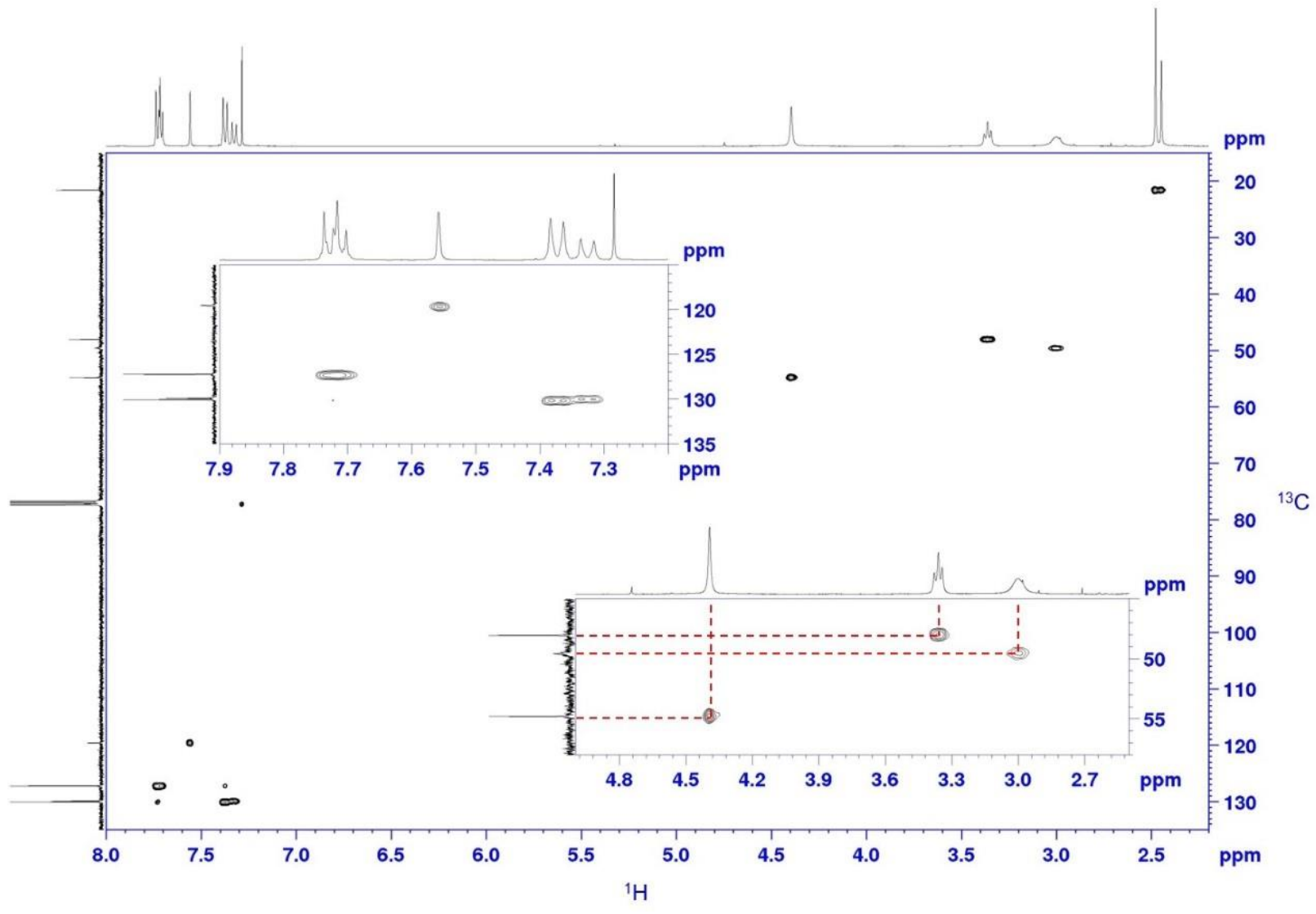

Figure S53. ${ }^{1} \mathrm{H}_{-}{ }^{13} \mathrm{C}$ HSQC NMR spectrum of 26 in $\mathrm{CDCl}_{3}$.

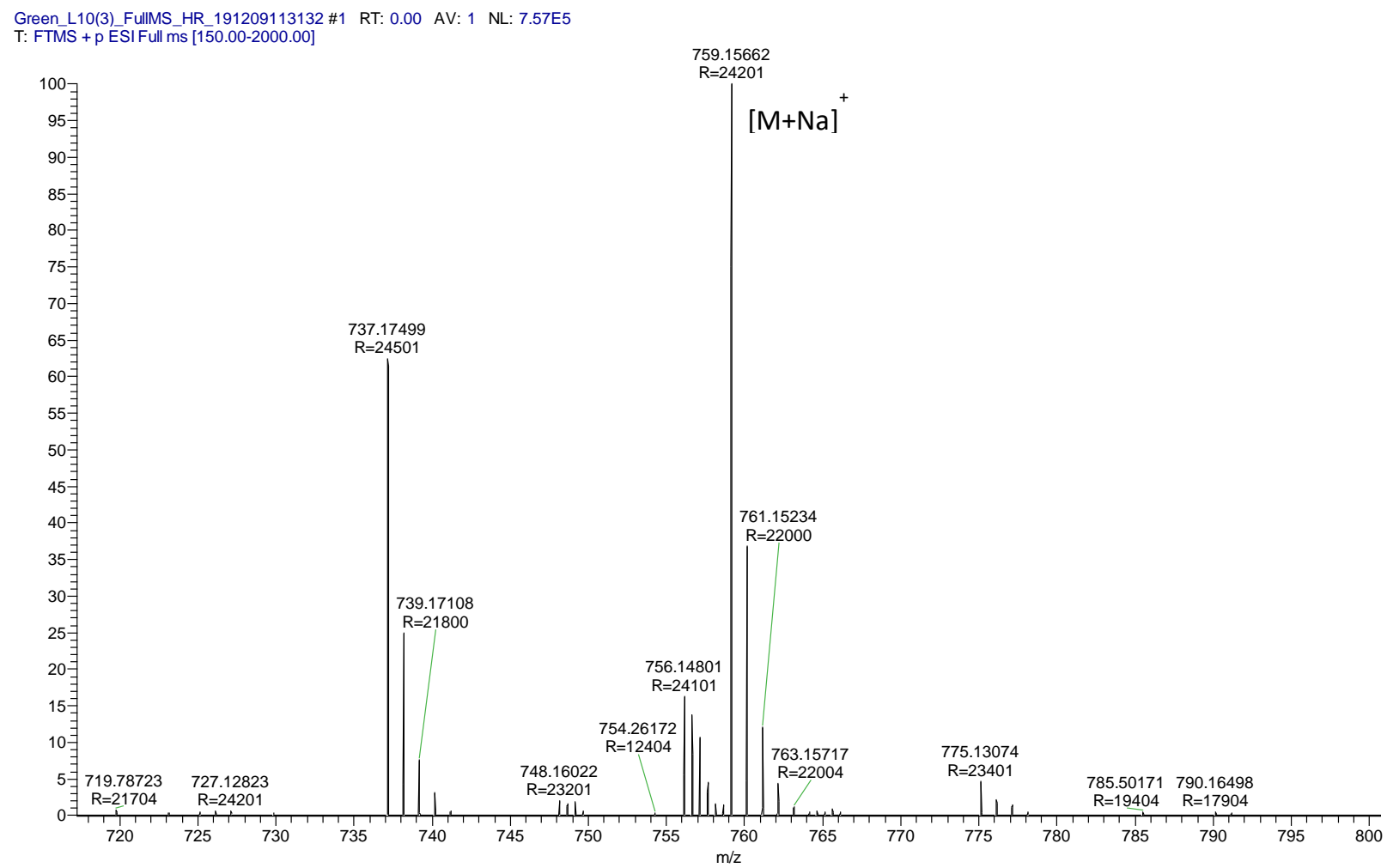

Figure S54. HR-MS of compound 26. 


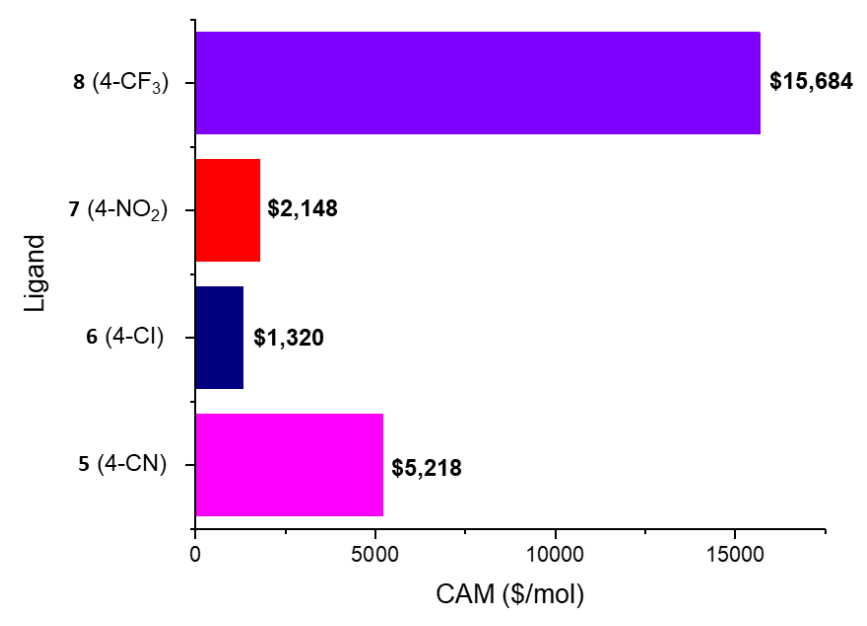

Figure S55. CAM analysis of 5-8.

Table S1. Protonation constants ${ }^{[\mathrm{a}]}\left(\mathrm{p} K_{\mathrm{a}}\right)$ of $2 \mathbf{2}, \mathbf{1}, \mathbf{6}, \mathbf{8}$ and 5. $(I=0.15 \mathrm{M} \mathrm{NaCl}$ and $T=298 \mathrm{~K})$.

\begin{tabular}{|c|c|c|c|c|c|}
\hline & $\mathbf{2 a}(4-\mathrm{OH})^{[\mathrm{b}]}$ & $\mathbf{1}(4-\mathrm{H})^{[\mathrm{b}]}$ & $\mathbf{6}(4-\mathrm{Cl})$ & $\mathbf{8}\left(4-\mathrm{CF}_{3}\right)$ & $\mathbf{5}(4-\mathrm{CN})$ \\
\hline $\log K_{1}{ }^{\mathrm{H}}$ & 11.56 & 11.37 & $10.50(2)$ & $11.36(2)$ & $10.60(3)$ \\
\hline $\log K_{2}{ }^{\mathrm{H}}$ & 9.05 & 8.22 & $7.27(4)$ & $7.76(6)^{[\mathrm{d}]}$ & $7.00(6)$ \\
\hline $\log K_{3}{ }^{\mathrm{H}}$ & $5.45^{[\mathrm{c}]}$ & 1.61 & $1.37(4)$ & & $0.85(6)$ \\
\hline $\log K_{4}{ }^{\mathrm{H}}$ & 1.68 & - & - & & - \\
\hline$\sum \log K_{i}^{\mathrm{H}}$ & 27.74 & 21.20 & 19.14 & 19.12 & 18.45 \\
\hline$\Sigma \log K_{\mathrm{N} \text {-donor }}^{\mathrm{H}}$ & 22.29 & 21.20 & 19.14 & 19.12 & 18.45 \\
\hline
\end{tabular}

[a] Defined as $K_{i}^{\mathrm{H}}=\left[\mathrm{H}_{i} \mathrm{~L}^{i+}\right] /\left(\left[\mathrm{H}^{+}\right]\left[\mathrm{H}_{i-1} \mathrm{~L}^{(i-1)+}\right]\right)$ for $i=1-4$. [b] ref. ${ }^{1}$. [c] Assigned as protonation of the OH moiety. ${ }^{1-2}$ [d] The third protonation step could not be modeled separately due to its very acidic character and the limits of the experimental setup. However, the total basicity of $\mathbf{8}$ reflects the electronic effects of the trifluoromethyl group.

a)

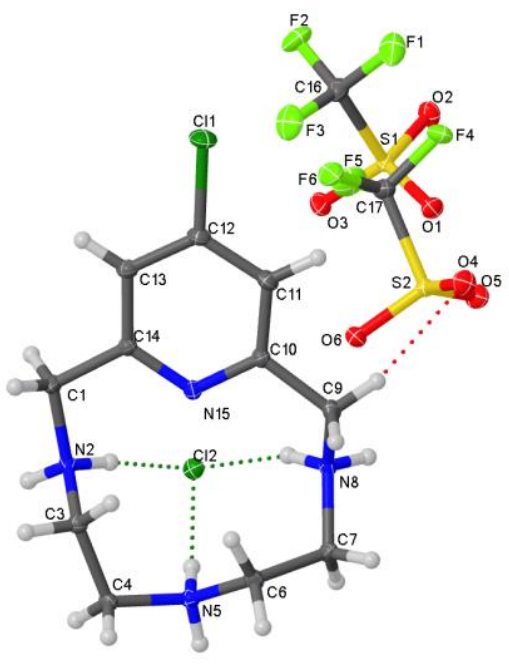

b)

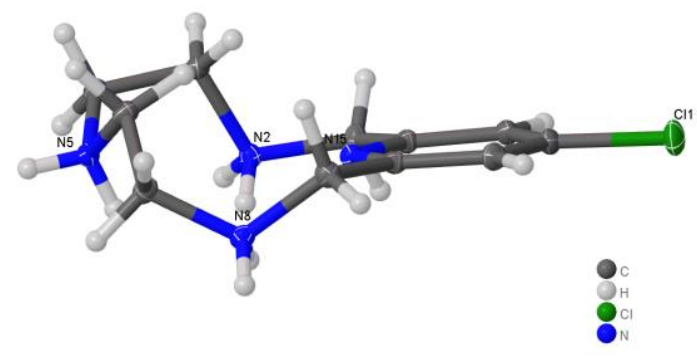

Figure S56. Solid state structure of $\mathbf{6} \cdot \mathbf{H C l} \cdot \mathbf{2 H O T f}$ showing atom labeling scheme from a) top view and b) side view. Crystal obtained by slow evaporation from methanol. 
a)

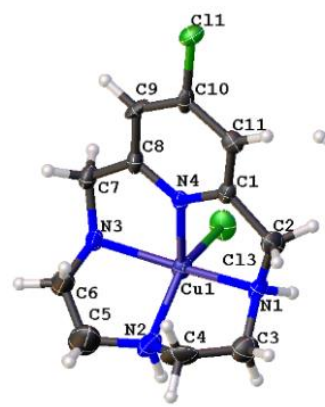

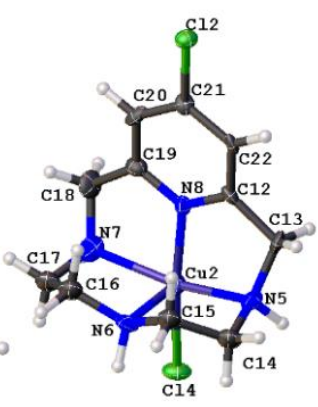

b)
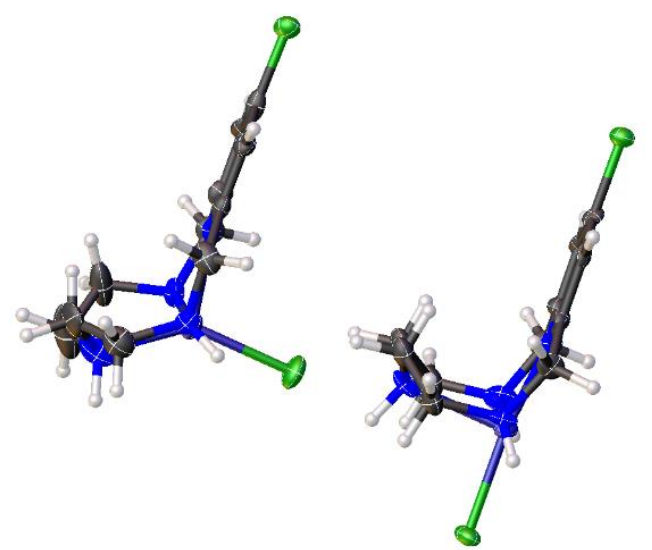

Figure S57. Solid state structure of $\mathbf{C u 6}$ showing atom labeling scheme from a) top view and b) side view. Perchlorate counter ions have been removed for clarity. Crystals obtained by slow evaporation from an aqueous solution

Table S2. Crystal data, intensity collections, and structure refinement parameters for $\mathbf{6} \cdot \mathbf{H C l} \cdot \mathbf{2 H O T f}$.

\begin{tabular}{|c|c|c|}
\hline & $6 \cdot \mathrm{HCl} \cdot 2 \mathrm{HOTf}$ & $\mathrm{Cu} 6$ \\
\hline Empirical formula & $\mathrm{C}_{13} \mathrm{H}_{20} \mathrm{Cl}_{2} \mathrm{~F}_{6} \mathrm{~N}_{4} \mathrm{O}_{6} \mathrm{~S}_{2}$ & $\mathrm{C}_{33} \mathrm{H}_{49.5} \mathrm{Cl}_{8.94} \mathrm{Cu}_{3} \mathrm{~N}_{12} \mathrm{O}_{12.09}$ \\
\hline Formula weight & 577.355 & 1315.313 \\
\hline Temperature/K & 100.15 & 99.89 \\
\hline Crystal system & monoclinic & monoclinic \\
\hline Space group & $\mathrm{P} 2{ }_{1} / \mathrm{c}$ & $\mathrm{C} 2 / \mathrm{m}$ \\
\hline $\mathrm{a} / \AA$ & $11.471(1)$ & $26.405(3)$ \\
\hline $\mathrm{b} / \mathrm{A}$ & $7.8357(7)$ & $29.055(3)$ \\
\hline $\mathrm{c} / \AA$ & $24.225(3)$ & $13.1898(11)$ \\
\hline$\alpha /^{\circ}$ & 90 & 90 \\
\hline$\beta /{ }^{\circ}$ & $90.475(3)$ & $105.232(3)$ \\
\hline$\gamma /{ }^{\circ}$ & 90 & 90 \\
\hline Volume $/ \AA^{3}$ & $2177.3(4)$ & $9763.6(15)$ \\
\hline $\mathrm{Z}$ & 4 & 8 \\
\hline$\rho_{\text {calc }} \mathrm{g} / \mathrm{cm}^{3}$ & 1.761 & 1.79 \\
\hline$\mu / \mathrm{mm}^{-1}$ & 0.581 & 1.855 \\
\hline $\mathrm{F}(000)$ & 1179.0 & 5358.5 \\
\hline Crystal size $/ \mathrm{mm}^{3}$ & $0.214 \times 0.135 \times 0.082$ & $0.212 \times 0.174 \times 0.079$ \\
\hline Radiation & Mo $\mathrm{K} \alpha(\lambda=0.71073)$ & Mo K $\alpha(\lambda=0.71073)$ \\
\hline $2 \Theta$ range for data collection ${ }^{\circ}$ & 4.88 to 72.6 & 5.76 to 44.96 \\
\hline Index ranges & $\begin{array}{l}-19 \leq \mathrm{h} \leq 18,-12 \leq \mathrm{k} \leq 12,-40 \leq 1 \leq \\
40\end{array}$ & $\begin{array}{l}-28 \leq \mathrm{h} \leq 28,-31 \leq \mathrm{k} \leq 31,- \\
14 \leq 1 \leq 14\end{array}$ \\
\hline
\end{tabular}


Table S3. Computational details of ligands 1-8 modeled using the B3LYP 6-31++G(d,p) basis set.

\begin{tabular}{ccccccc}
\hline Ligand & $\begin{array}{c}\text { Total Gibbs } \\
\text { Free Energy } \\
\text { (a.u.) }\end{array}$ & $\begin{array}{c}\text { Zero-point } \\
\text { correction } \\
\text { (a.u.) }\end{array}$ & $\begin{array}{c}\text { Thermal } \\
\text { correction } \\
\text { to Energy } \\
\text { (a.u.) }\end{array}$ & $\begin{array}{c}\text { Thermal } \\
\text { correction } \\
\text { to Enthalpy } \\
\text { (a.u.) }\end{array}$ & $\begin{array}{c}\text { Thermal } \\
\text { correction to } \\
\text { Gibbs Free } \\
\text { Energy (a.u.) }\end{array}$ & $\begin{array}{c}\text { Number of } \\
\text { imaginary } \\
\text { frequencies }\end{array}$ \\
\hline $\mathbf{1}$ & -649.0162493 & 0.289396 & 0.30302 & 0.303964 & 0.249836 & 0 \\
\hline $\mathbf{2 a}$ & -724.2716246 & 0.295952 & 0.310333 & 0.311278 & 0.255244 & 0 \\
\hline $\mathbf{5}$ & -741.2764048 & 0.28918 & 0.304223 & 0.305167 & 0.247471 & 0 \\
\hline $\mathbf{6}$ & -1108.611522 & 0.279624 & 0.294578 & 0.295522 & 0.237725 & 0 \\
\hline $\mathbf{7}$ & -853.5406396 & 0.293073 & 0.308873 & 0.309817 & 0.249779 & 0 \\
\hline $\mathbf{8}$ & -986.0742993 & 0.293391 & 0.310918 & 0.311863 & 0.246924 & 0 \\
\hline
\end{tabular}

Table S4. Computational details for 1 using B3LYP 6-31++G(d,p) basis set.

Total Gibbs Free Energy (a.u.)

Zero-point correction (a.u.)

Thermal correction to Energy (a.u.)

Thermal correction to Enthalpy (a.u.)

Thermal correction to Gibbs Free Energy (a.u.)

Number of imaginary frequencies
$-649.01624929$

0.289396

0.303020

0.303964

0.249836

0

Cartesian Coordinates

$\begin{array}{rrrrrrrr}1 \mathrm{C} 1 & 1.2533 & -0.3690 & 1.1530 \mathrm{C} & 18 \mathrm{C} 18 & -1.6486 & 0.1465 & -2.4636 \mathrm{C} \\ \text { 2 C2 } & 2.2316 & 0.6351 & 1.2003 \mathrm{C} & 19 \mathrm{H} 19 & -1.3737 & 0.7715 & -3.3386 \mathrm{H} \\ \text { 3 C3 } & 2.7469 & 1.1239 & 0.0000 \mathrm{C} & 20 \mathrm{H} 20 & -2.6790 & -0.1914 & -2.6333 \mathrm{H} \\ \text { 4 C4 } & 2.2316 & 0.6351 & -1.2003 \mathrm{C} & 21 \mathrm{C} 21 & -1.6334 & 1.0801 & -1.2366 \mathrm{C} \\ \text { 5 C5 } & 1.2533 & -0.3690 & -1.1530 \mathrm{C} & 22 \mathrm{H} 22 & -0.6256 & 1.4909 & -1.1093 \mathrm{H} \\ \text { 6 N6 } & 0.8192 & -0.8890 & 0.0000 \mathrm{~N} & 23 \mathrm{H} 23 & -2.2774 & 1.9476 & -1.4925 \mathrm{H} \\ \text { 7 H7 } & 2.5657 & 1.0324 & 2.1548 \mathrm{H} & 24 \mathrm{C} 24 & -1.6334 & 1.0801 & 1.2366 \mathrm{C} \\ \text { 8 H8 } & 2.5657 & 1.0324 & -2.1548 \mathrm{H} & 25 \mathrm{H} 25 & -0.6256 & 1.4909 & 1.1093 \mathrm{H} \\ \text { 9 C9 } & 0.6189 & -0.9050 & 2.4328 \mathrm{C} & 26 \mathrm{H} 26 & -2.2774 & 1.9476 & 1.4925 \mathrm{H} \\ 10 \mathrm{C} 10 & 0.6189 & -0.9050 & -2.4328 \mathrm{C} & 27 \mathrm{~N} 27 & -1.9927 & 0.4205 & 0.0000 \mathrm{~N} \\ 11 \mathrm{H} 11 & 0.9380 & -0.2557 & 3.2721 \mathrm{H} & 28 \mathrm{H} 28 & 0.9380 & -0.2557 & -3.2721 \mathrm{H} \\ 12 \mathrm{H} 12 & 1.0337 & -1.9022 & -2.6266 \mathrm{H} & 29 \mathrm{H} 29 & 1.0337 & -1.9022 & 2.6266 \mathrm{H} \\ 13 \mathrm{~N} 13 & -0.8265 & -1.0517 & 2.3486 \mathrm{~N} & 30 \mathrm{H} 30 & 3.5100 & 1.8976 & 0.0000 \mathrm{H} \\ 14 \mathrm{~N} 14 & -0.8265 & -1.0517 & -2.3486 \mathrm{~N} & 31 \mathrm{H} 31 & -2.9395 & 0.0575 & 0.0000 \mathrm{H} \\ 15 \mathrm{C} 15 & -1.6486 & 0.1465 & 2.4636 \mathrm{C} & 32 \mathrm{H} 32 & -1.1465 & -1.7670 & -2.9888 \mathrm{H} \\ 16 \mathrm{H} 16 & -2.6790 & -0.1914 & 2.6333 \mathrm{H} & 33 \mathrm{H} 33 & -1.1465 & -1.7670 & 2.9888 \mathrm{H} \\ 17 \mathrm{H} 17 & -1.3737 & 0.7715 & 3.3386 \mathrm{H} & & & & \end{array}$


Table S5. Computational details for 2a using B3LYP 6-31++G(d,p) basis set.

\begin{tabular}{|c|c|c|c|c|c|c|c|}
\hline \multicolumn{4}{|c|}{ Total Gibbs Free Energy (a.u.) } & \multicolumn{4}{|c|}{-724.27162459} \\
\hline \multicolumn{4}{|c|}{ Zero-point correction (a.u.) } & \multicolumn{4}{|c|}{0.295952} \\
\hline \multicolumn{4}{|c|}{ Thermal correction to Energy (a.u.) } & \multicolumn{4}{|c|}{0.310333} \\
\hline \multicolumn{4}{|c|}{ Thermal correction to Enthalpy (a.u.) } & \multicolumn{4}{|c|}{0.311278} \\
\hline \multicolumn{4}{|c|}{ Thermal correction to Gibbs Free Energy (a.u.) } & \multicolumn{4}{|c|}{0.255244} \\
\hline \multicolumn{4}{|c|}{ Number of imaginary frequencies } & \multicolumn{4}{|c|}{0} \\
\hline \multicolumn{8}{|c|}{ Cartesian coordinates } \\
\hline $1 \mathrm{C} 1$ & 0.4827 & 0.9944 & $1.1954 \mathrm{C}$ & $18 \mathrm{C} 18$ & -0.2501 & -1.9671 & $-2.4350 \mathrm{C}$ \\
\hline $2 \mathrm{C} 2$ & -0.1506 & 2.2025 & $1.2243 \mathrm{C}$ & 19 H19 & -0.8062 & -1.6713 & $-3.3439 \mathrm{H}$ \\
\hline $3 \mathrm{C} 3$ & -0.5019 & 2.9192 & $0.0000 \mathrm{C}$ & $20 \mathrm{H} 20$ & 0.0389 & -3.0173 & $-2.5657 \mathrm{H}$ \\
\hline $4 \mathrm{C} 4$ & -0.1506 & 2.2025 & $-1.2243 \mathrm{C}$ & $21 \mathrm{C} 21$ & -1.2134 & -1.8626 & $-1.2416 \mathrm{C}$ \\
\hline $5 \mathrm{C} 5$ & 0.4827 & 0.9944 & $-1.1954 \mathrm{C}$ & $22 \mathrm{H} 22$ & -1.5404 & -0.8235 & $-1.1240 \mathrm{H}$ \\
\hline $6 \mathrm{~N} 6$ & 0.8223 & 0.4145 & $0.0000 \mathrm{~N}$ & $23 \mathrm{H} 23$ & -2.1219 & -2.4426 & $-1.4901 \mathrm{H}$ \\
\hline $7 \mathrm{H} 7$ & -0.4151 & 2.6588 & $2.1729 \mathrm{H}$ & 24 C24 & -1.2134 & -1.8626 & $1.2416 \mathrm{C}$ \\
\hline $8 \mathrm{H} 8$ & -0.4151 & 2.6588 & $-2.1729 \mathrm{H}$ & $25 \mathrm{H} 25$ & -1.5404 & -0.8235 & $1.1240 \mathrm{H}$ \\
\hline 9 C9 & 0.9029 & 0.2465 & $2.4511 \mathrm{C}$ & 26 H26 & -2.1219 & -2.4426 & $1.4901 \mathrm{H}$ \\
\hline $10 \mathrm{C} 10$ & 0.9029 & 0.2465 & $-2.4511 \mathrm{C}$ & 27 N27 & -0.5735 & -2.2698 & $0.0000 \mathrm{~N}$ \\
\hline $11 \mathrm{H} 11$ & 0.2219 & 0.5405 & $3.2670 \mathrm{H}$ & $28 \mathrm{H} 28$ & 0.2219 & 0.5405 & $-3.2670 \mathrm{H}$ \\
\hline $12 \mathrm{H} 12$ & 1.9038 & 0.5983 & $-2.7309 \mathrm{H}$ & $29 \mathrm{H} 29$ & 1.9038 & 0.5983 & $2.7309 \mathrm{H}$ \\
\hline 13 N13 & 0.9865 & -1.1995 & $2.2683 \mathrm{~N}$ & $30 \mathrm{H} 30$ & -0.3560 & -3.2625 & $0.0000 \mathrm{H}$ \\
\hline 14 N14 & 0.9865 & -1.1995 & $-2.2683 \mathrm{~N}$ & 31 H31 & 1.7171 & -1.5823 & $-2.8553 \mathrm{H}$ \\
\hline $15 \mathrm{C} 15$ & -0.2501 & -1.9671 & $2.4350 \mathrm{C}$ & 32 H32 & 1.7171 & -1.5823 & $2.8553 \mathrm{H}$ \\
\hline $16 \mathrm{H} 16$ & 0.0389 & -3.0173 & $2.5657 \mathrm{H}$ & $33 \mathrm{O} 33$ & -1.0677 & 4.0265 & $0.0000 \mathrm{O}$ \\
\hline $17 \mathrm{H} 17$ & -0.8062 & -1.6713 & $3.3439 \mathrm{H}$ & 34 H34 & 1.1019 & -0.5698 & $0.0000 \mathrm{H}$ \\
\hline
\end{tabular}


Table S6. Computational details for 5 using B3LYP 6-31++G(d,p) basis set.

\begin{tabular}{|c|c|c|c|c|c|c|c|}
\hline \multicolumn{4}{|c|}{ Total Gibbs Free Energy (a.u.) } & \multicolumn{4}{|c|}{-741.27640477} \\
\hline \multicolumn{4}{|c|}{ Zero-point correction (a.u.) } & \multicolumn{4}{|c|}{0.289180} \\
\hline \multicolumn{4}{|c|}{ Thermal correction to Energy (a.u.) } & \multicolumn{4}{|c|}{0.304223} \\
\hline \multicolumn{4}{|c|}{ Thermal correction to Enthalpy (a.u.) } & \multicolumn{4}{|c|}{0.305167} \\
\hline \multicolumn{4}{|c|}{ Thermal correction to Gibbs Free Energy (a.u.) } & \multicolumn{4}{|c|}{0.247471} \\
\hline \multicolumn{4}{|c|}{ Number of imaginary frequencies } & \multicolumn{4}{|c|}{0} \\
\hline \multicolumn{8}{|c|}{ Cartesian coordinates } \\
\hline $1 \mathrm{C} 1$ & 0.7442 & 0.6331 & $1.1578 \mathrm{C}$ & $18 \mathrm{C} 18$ & -0.5011 & -2.1001 & $-2.4504 \mathrm{C}$ \\
\hline $2 \mathrm{C} 2$ & 0.1684 & 1.9074 & $1.2091 \mathrm{C}$ & $19 \mathrm{H} 19$ & -1.0249 & -1.6894 & $-3.3344 \mathrm{H}$ \\
\hline $3 \mathrm{C} 3$ & -0.1001 & 2.5636 & $0.0000 \mathrm{C}$ & $20 \mathrm{H} 20$ & -0.4123 & -3.1826 & $-2.5898 \mathrm{H}$ \\
\hline $4 \mathrm{C} 4$ & 0.1684 & 1.9074 & $-1.2091 \mathrm{C}$ & $21 \mathrm{C} 21$ & -1.3710 & -1.8333 & $-1.2160 \mathrm{C}$ \\
\hline $5 \mathrm{C} 5$ & 0.7442 & 0.6331 & $-1.1578 \mathrm{C}$ & $22 \mathrm{H} 22$ & -1.5760 & -0.7452 & $-1.1467 \mathrm{H}$ \\
\hline 6 N6 & 1.0584 & 0.0409 & $0.0000 \mathrm{~N}$ & $23 \mathrm{H} 23$ & -2.3471 & -2.3122 & $-1.3763 \mathrm{H}$ \\
\hline $7 \mathrm{H} 7$ & -0.0777 & 2.3747 & $2.1569 \mathrm{H}$ & 24 C24 & -1.3710 & -1.8333 & $1.2160 \mathrm{C}$ \\
\hline $8 \mathrm{H} 8$ & -0.0777 & 2.3747 & $-2.1569 \mathrm{H}$ & $25 \mathrm{H} 25$ & -1.5760 & -0.7452 & $1.1467 \mathrm{H}$ \\
\hline $9 \mathrm{C} 9$ & 1.0510 & -0.1393 & $2.4392 \mathrm{C}$ & $26 \mathrm{H} 26$ & -2.3471 & -2.3122 & $1.3763 \mathrm{H}$ \\
\hline $10 \mathrm{C} 10$ & 1.0510 & -0.1393 & $-2.4392 \mathrm{C}$ & 27 N27 & -0.7595 & -2.3477 & $0.0000 \mathrm{~N}$ \\
\hline $11 \mathrm{H} 11$ & 0.4581 & 0.3062 & $3.2598 \mathrm{H}$ & $28 \mathrm{H} 28$ & 0.4581 & 0.3062 & $-3.2598 \mathrm{H}$ \\
\hline $12 \mathrm{H} 12$ & 2.1069 & 0.0325 & $-2.6841 \mathrm{H}$ & $29 \mathrm{H} 29$ & 2.1069 & 0.0325 & $2.6841 \mathrm{H}$ \\
\hline $13 \mathrm{~N} 13$ & 0.8591 & -1.5756 & $2.3154 \mathrm{~N}$ & $30 \mathrm{H} 30$ & 0.2286 & -2.0895 & $0.0000 \mathrm{H}$ \\
\hline $14 \mathrm{~N} 14$ & 0.8591 & -1.5756 & $-2.3154 \mathrm{~N}$ & 31 H31 & 1.5003 & -2.0745 & $-2.9181 \mathrm{H}$ \\
\hline $15 \mathrm{C} 15$ & -0.5011 & -2.1001 & $2.4504 \mathrm{C}$ & 32 H32 & 1.5003 & -2.0745 & $2.9181 \mathrm{H}$ \\
\hline $16 \mathrm{H} 16$ & -0.4123 & -3.1826 & $2.5898 \mathrm{H}$ & 33 C33 & -0.6800 & 3.8783 & $0.0000 \mathrm{C}$ \\
\hline $17 \mathrm{H} 17$ & -1.0249 & -1.6894 & $3.3344 \mathrm{H}$ & 34 N34 & -1.1456 & 4.9444 & $0.0000 \mathrm{~N}$ \\
\hline
\end{tabular}


Table S7. Computational details for 6 using B3LYP 6-31++G(d,p) basis set.

\begin{tabular}{|c|c|c|c|c|c|c|c|}
\hline \multicolumn{4}{|c|}{ Total Gibbs Free Energy (a.u.) } & \multicolumn{4}{|c|}{-1108.61152168} \\
\hline \multicolumn{4}{|c|}{ Zero-point correction (a.u.) } & \multicolumn{4}{|c|}{0.279624} \\
\hline \multicolumn{4}{|c|}{ Thermal correction to Energy (a.u.) } & \multicolumn{4}{|c|}{0.294578} \\
\hline \multicolumn{4}{|c|}{ Thermal correction to Enthalpy (a.u.) } & \multicolumn{4}{|c|}{0.295522} \\
\hline \multicolumn{4}{|c|}{ Thermal correction to Gibbs Free Energy (a.u.) } & \multicolumn{4}{|c|}{0.237725} \\
\hline \multicolumn{4}{|c|}{ Number of imaginary frequencies } & \multicolumn{4}{|c|}{0} \\
\hline \multicolumn{8}{|c|}{ Cartesian coordinates } \\
\hline $1 \mathrm{C} 1$ & 0.8760 & 0.5000 & $1.1510 \mathrm{C}$ & $18 \mathrm{C} 18$ & -0.5408 & -2.0820 & $-2.4652 \mathrm{C}$ \\
\hline $2 \mathrm{C} 2$ & 0.2290 & 1.7438 & $1.2061 \mathrm{C}$ & 19 H19 & -1.0459 & -1.6230 & $-3.3398 \mathrm{H}$ \\
\hline $3 \mathrm{C} 3$ & -0.0645 & 2.3725 & $0.0000 \mathrm{C}$ & $20 \mathrm{H} 20$ & -0.5468 & -3.1662 & $-2.6350 \mathrm{H}$ \\
\hline $4 \mathrm{C} 4$ & 0.2290 & 1.7438 & $-1.2061 \mathrm{C}$ & $21 \mathrm{C} 21$ & -1.4200 & -1.7723 & $-1.2369 \mathrm{C}$ \\
\hline $5 \mathrm{C} 5$ & 0.8760 & 0.5000 & $-1.1510 \mathrm{C}$ & $22 \mathrm{H} 22$ & -1.5036 & -0.6858 & $-1.1173 \mathrm{H}$ \\
\hline $6 \mathrm{~N} 6$ & 1.2351 & -0.0759 & $0.0000 \mathrm{~N}$ & $23 \mathrm{H} 23$ & -2.4438 & -2.1220 & $-1.4851 \mathrm{H}$ \\
\hline $7 \mathrm{H} 7$ & -0.0486 & 2.1934 & $2.1533 \mathrm{H}$ & $24 \mathrm{C} 24$ & -1.4200 & -1.7723 & $1.2369 \mathrm{C}$ \\
\hline $8 \mathrm{H} 8$ & -0.0486 & 2.1934 & $-2.1533 \mathrm{H}$ & $25 \mathrm{H} 25$ & -1.5036 & -0.6858 & $1.1173 \mathrm{H}$ \\
\hline $9 \mathrm{C} 9$ & 1.1790 & -0.2676 & $2.4346 \mathrm{C}$ & 26 H26 & -2.4438 & -2.1220 & $1.4851 \mathrm{H}$ \\
\hline $10 \mathrm{C} 10$ & 1.1790 & -0.2676 & $-2.4346 \mathrm{C}$ & 27 N27 & -0.8939 & -2.3064 & $0.0000 \mathrm{~N}$ \\
\hline $11 \mathrm{H} 11$ & 0.6644 & 0.2445 & $3.2713 \mathrm{H}$ & $28 \mathrm{H} 28$ & 0.6644 & 0.2445 & $-3.2713 \mathrm{H}$ \\
\hline $12 \mathrm{H} 12$ & 2.2561 & -0.1908 & $-2.6280 \mathrm{H}$ & $29 \mathrm{H} 29$ & 2.2561 & -0.1908 & $2.6280 \mathrm{H}$ \\
\hline $13 \mathrm{~N} 13$ & 0.8568 & -1.6832 & $2.3500 \mathrm{~N}$ & 30 H30 & -0.8138 & -3.3172 & $0.0000 \mathrm{H}$ \\
\hline 14 N14 & 0.8568 & -1.6832 & $-2.3500 \mathrm{~N}$ & $31 \mathrm{H} 31$ & 1.4359 & -2.2162 & $-2.9858 \mathrm{H}$ \\
\hline $15 \mathrm{C} 15$ & -0.5408 & -2.0820 & $2.4652 \mathrm{C}$ & $32 \mathrm{H} 32$ & 1.4359 & -2.2162 & $2.9858 \mathrm{H}$ \\
\hline $16 \mathrm{H} 16$ & -0.5468 & -3.1662 & $2.6350 \mathrm{H}$ & $33 \mathrm{Cl} 33$ & -0.8586 & 3.9407 & $0.0000 \mathrm{Cl}$ \\
\hline $17 \mathrm{H} 17$ & -1.0459 & -1.6230 & $3.3398 \mathrm{H}$ & & & & \\
\hline
\end{tabular}


Table S8. Computational details for 7 using B3LYP 6-31++G(d,p) basis set.

\begin{tabular}{|c|c|c|c|c|c|c|c|}
\hline \multicolumn{4}{|c|}{ Total Gibbs Free Energy (a.u.) } & \multicolumn{4}{|c|}{-853.54063955} \\
\hline \multicolumn{4}{|c|}{ Zero-point correction (a.u.) } & \multicolumn{4}{|c|}{0.293073} \\
\hline \multicolumn{4}{|c|}{ Thermal correction to Energy (a.u.) } & \multicolumn{4}{|c|}{0.308873} \\
\hline \multicolumn{4}{|c|}{ Thermal correction to Enthalpy (a.u.) } & \multicolumn{4}{|c|}{0.309817} \\
\hline \multicolumn{4}{|c|}{ Thermal correction to Gibbs Free Energy (a.u.) } & \multicolumn{4}{|c|}{0.249779} \\
\hline \multicolumn{4}{|c|}{ Number of imaginary frequencies } & \multicolumn{4}{|c|}{0} \\
\hline \multicolumn{8}{|c|}{ Cartesian coordinates } \\
\hline $1 \mathrm{C} 1$ & -0.2947 & 1.1587 & $-0.8255 \mathrm{C}$ & 19 H19 & 1.9232 & -3.3345 & $1.0599 \mathrm{H}$ \\
\hline $2 \mathrm{C} 2$ & -1.5917 & 1.2124 & $-0.2979 \mathrm{C}$ & 20 H20 & 3.4485 & -2.5908 & $0.5312 \mathrm{H}$ \\
\hline $3 \mathrm{C} 3$ & -2.2303 & 0.0000 & $-0.0658 \mathrm{C}$ & $21 \mathrm{C} 21$ & 2.0486 & -1.2163 & $1.4129 \mathrm{C}$ \\
\hline $4 \mathrm{C} 4$ & -1.5917 & -1.2124 & $-0.2979 \mathrm{C}$ & $22 \mathrm{H} 22$ & 0.9512 & -1.1475 & $1.5598 \mathrm{H}$ \\
\hline $5 \mathrm{C} 5$ & -0.2947 & -1.1587 & $-0.8255 \mathrm{C}$ & $23 \mathrm{H} 23$ & 2.4748 & -1.3750 & $2.4134 \mathrm{H}$ \\
\hline $6 \mathrm{~N} 6$ & 0.3080 & 0.0000 & $-1.1162 \mathrm{~N}$ & $24 \mathrm{C} 24$ & 2.0486 & 1.2163 & $1.4129 \mathrm{C}$ \\
\hline $7 \mathrm{H} 7$ & -2.0827 & 2.1496 & $-0.0661 \mathrm{H}$ & $25 \mathrm{H} 25$ & 0.9512 & 1.1475 & $1.5598 \mathrm{H}$ \\
\hline $8 \mathrm{H} 8$ & -2.0827 & -2.1496 & $-0.0661 \mathrm{H}$ & 26 H26 & 2.4748 & 1.3750 & $2.4134 \mathrm{H}$ \\
\hline $9 \mathrm{C} 9$ & 0.4908 & 2.4393 & $-1.0983 \mathrm{C}$ & 27 N27 & 2.5933 & 0.0000 & $0.8294 \mathrm{~N}$ \\
\hline $10 \mathrm{C} 10$ & 0.4908 & -2.4393 & $-1.0983 \mathrm{C}$ & $28 \mathrm{H} 28$ & 0.0127 & -3.2617 & $-0.5347 \mathrm{H}$ \\
\hline $11 \mathrm{H} 11$ & 0.0127 & 3.2617 & $-0.5347 \mathrm{H}$ & 29 H29 & 0.3764 & 2.6780 & $-2.1632 \mathrm{H}$ \\
\hline $12 \mathrm{H} 12$ & 0.3764 & -2.6780 & $-2.1632 \mathrm{H}$ & 30 H30 & 2.3939 & 0.0000 & $-0.1721 \mathrm{H}$ \\
\hline 13 N13 & 1.9148 & 2.3160 & $-0.8278 \mathrm{~N}$ & 31 H31 & 2.4480 & -2.9193 & $-1.4402 \mathrm{H}$ \\
\hline 14 N14 & 1.9148 & -2.3160 & $-0.8278 \mathrm{~N}$ & 32 H32 & 2.4480 & 2.9193 & $-1.4402 \mathrm{H}$ \\
\hline $15 \mathrm{C} 15$ & 2.3628 & 2.4510 & $0.5597 \mathrm{C}$ & 33 N33 & -3.6060 & 0.0000 & $0.4814 \mathrm{~N}$ \\
\hline $16 \mathrm{H} 16$ & 3.4485 & 2.5908 & $0.5312 \mathrm{H}$ & $34 \mathrm{O} 34$ & -4.1363 & -1.0906 & $0.6914 \mathrm{O}$ \\
\hline 17 H17 & 1.9232 & 3.3345 & $1.0599 \mathrm{H}$ & $35 \mathrm{O} 35$ & -4.1363 & 1.0906 & $0.6914 \mathrm{O}$ \\
\hline $18 \mathrm{C} 18$ & 2.3628 & -2.4510 & $0.5597 \mathrm{C}$ & & & & \\
\hline
\end{tabular}


Table S9. Computational details for 8 using B3LYP 6-31++G(d,p) basis set.

\begin{tabular}{|c|c|c|c|c|c|c|c|}
\hline \multicolumn{4}{|c|}{ Total Gibbs Free Energy (a.u.) } & \multicolumn{4}{|c|}{-986.07429927} \\
\hline \multicolumn{4}{|c|}{ Zero-point correction (a.u.) } & \multicolumn{4}{|c|}{0.293391} \\
\hline \multicolumn{4}{|c|}{ Thermal correction to Energy (a.u.) } & \multicolumn{4}{|c|}{0.310918} \\
\hline \multicolumn{4}{|c|}{ Thermal correction to Enthalpy (a.u.) } & \multicolumn{4}{|c|}{0.311863} \\
\hline \multicolumn{4}{|c|}{ Thermal correction to Gibbs Free Energy (a.u.) } & \multicolumn{4}{|c|}{0.246924} \\
\hline \multicolumn{4}{|c|}{ Number of imaginary frequencies } & \multicolumn{4}{|c|}{0} \\
\hline \multicolumn{8}{|c|}{ Cartesian coordinates } \\
\hline $1 \mathrm{C} 1$ & 0.0727 & 1.1571 & $-1.0033 \mathrm{C}$ & 19 H19 & 1.9731 & -3.3484 & $1.1101 \mathrm{H}$ \\
\hline $2 \mathrm{C} 2$ & -1.2229 & 1.2122 & $-0.4691 \mathrm{C}$ & $20 \mathrm{H} 20$ & 3.5593 & -2.6467 & $0.7671 \mathrm{H}$ \\
\hline $3 \mathrm{C} 3$ & -1.8918 & 0.0127 & $-0.2318 \mathrm{C}$ & $21 \mathrm{C} 21$ & 2.0880 & -1.2440 & $1.4932 \mathrm{C}$ \\
\hline $4 \mathrm{C} 4$ & -1.2318 & -1.1933 & $-0.4708 \mathrm{C}$ & $22 \mathrm{H} 22$ & 0.9952 & -1.1439 & $1.5028 \mathrm{H}$ \\
\hline $5 \mathrm{C} 5$ & 0.0629 & -1.1490 & $-1.0043 \mathrm{C}$ & $23 \mathrm{H} 23$ & 2.3723 & -1.4731 & $2.5416 \mathrm{H}$ \\
\hline $6 \mathrm{~N} 6$ & 0.6703 & 0.0024 & $-1.3122 \mathrm{~N}$ & $24 \mathrm{C} 24$ & 2.0955 & 1.2312 & $1.4953 \mathrm{C}$ \\
\hline $7 \mathrm{H} 7$ & -1.6891 & 2.1650 & $-0.2426 \mathrm{H}$ & $25 \mathrm{H} 25$ & 1.0020 & 1.1384 & $1.5030 \mathrm{H}$ \\
\hline $8 \mathrm{H} 8$ & -1.7054 & -2.1430 & $-0.2438 \mathrm{H}$ & $26 \mathrm{H} 26$ & 2.3796 & 1.4559 & $2.5447 \mathrm{H}$ \\
\hline $9 \mathrm{C} 9$ & 0.8693 & 2.4360 & $-1.2379 \mathrm{C}$ & 27 N27 & 2.6324 & -0.0076 & $0.9847 \mathrm{~N}$ \\
\hline $10 \mathrm{C} 10$ & 0.8496 & -2.4334 & $-1.2414 \mathrm{C}$ & $28 \mathrm{H} 28$ & 0.2850 & -3.2705 & $-0.7864 \mathrm{H}$ \\
\hline $11 \mathrm{H} 11$ & 0.3105 & 3.2766 & $-0.7822 \mathrm{H}$ & 29 H29 & 0.9017 & 2.6225 & $-2.3184 \mathrm{H}$ \\
\hline $12 \mathrm{H} 12$ & 0.8795 & -2.6183 & $-2.3222 \mathrm{H}$ & $30 \mathrm{H} 30$ & 3.6400 & -0.0105 & $0.8784 \mathrm{H}$ \\
\hline $13 \mathrm{~N} 13$ & 2.2458 & 2.3513 & $-0.7742 \mathrm{~N}$ & $31 \mathrm{H} 31$ & 2.8057 & -3.0087 & $-1.2971 \mathrm{H}$ \\
\hline 14 N14 & 2.2272 & -2.3596 & $-0.7792 \mathrm{~N}$ & 32 H32 & 2.8292 & 2.9982 & $-1.2895 \mathrm{H}$ \\
\hline $15 \mathrm{C} 15$ & 2.4985 & 2.4620 & $0.6585 \mathrm{C}$ & 33 C33 & -3.2739 & 0.0068 & $0.3686 \mathrm{C}$ \\
\hline $16 \mathrm{H} 16$ & 3.5773 & 2.6257 & $0.7750 \mathrm{H}$ & 34 F34 & -4.0481 & -0.9827 & $-0.1428 \mathrm{~F}$ \\
\hline $17 \mathrm{H} 17$ & 1.9953 & 3.3372 & $1.1172 \mathrm{H}$ & 35 F35 & -3.9309 & 1.1738 & $0.1662 \mathrm{~F}$ \\
\hline $18 \mathrm{C} 18$ & 2.4814 & -2.4754 & $0.6528 \mathrm{C}$ & 36 F36 & -3.2350 & -0.1912 & $1.7153 \mathrm{~F}$ \\
\hline
\end{tabular}

\section{REFERENCES}

1. Green, K. N.; Pota, K.; Tircsó, G.; Gogolák, R. A.; Kinsinger, O.; Davda, C.; Blain, K.; Brewer, S. M.; Gonzalez, P.; Johnston, H. M.; Akkaraju, G., Dialing in on pharmacological features for a therapeutic antioxidant small molecule. Dalton Trans. 2019, 48, 12430-12439.

2. Johnston, H. M.; Pota, K.; Barnett, M. M.; Kinsinger, O.; Braden, P.; Schwartz, T. M.; Hoffer, E.; Sadagopan, N.; Nguyen, N.; Yu, Y.; Gonzalez, P.; Tircsó, G.; Wu, H.; Akkaraju, G.; Chumley, M. J.; Green, K. N., Enhancement of the Antioxidant Activity and Neurotherapeutic Features through Pyridol Addition to Tetraazamacrocyclic Molecules. Inorg. Chem. 2019, 58 (24), 16771-16784. 